\title{
"Resistência à tração diametral de uma resina composta associada a pinos intra-radiculares pré-fabricados".
}

\section{Gildo Coelho Santos Júnior}

\begin{abstract}
Tese apresentada à Faculdade de Odontologia de Bauru, da Universidade de São Paulo, como parte dos requisitos para obtenção do título de Doutor em Odontologia, Área de Reabilitação Oral.

(Edição Revisada)
\end{abstract}




\section{"Resistência à tração diametral de uma resina composta associada a pinos intra-radiculares pré-fabricados".}

\section{Gildo Coelho Santos Júnior}

Tese apresentada à Faculdade de Odontologia de Bauru, da Universidade de São Paulo, como parte dos requisitos para obtenção do título de Doutor em Odontologia, Área de Reabilitação Oral.

(Edição Revisada)

Orientador:

Prof. Dr. José Henrique Rubo 


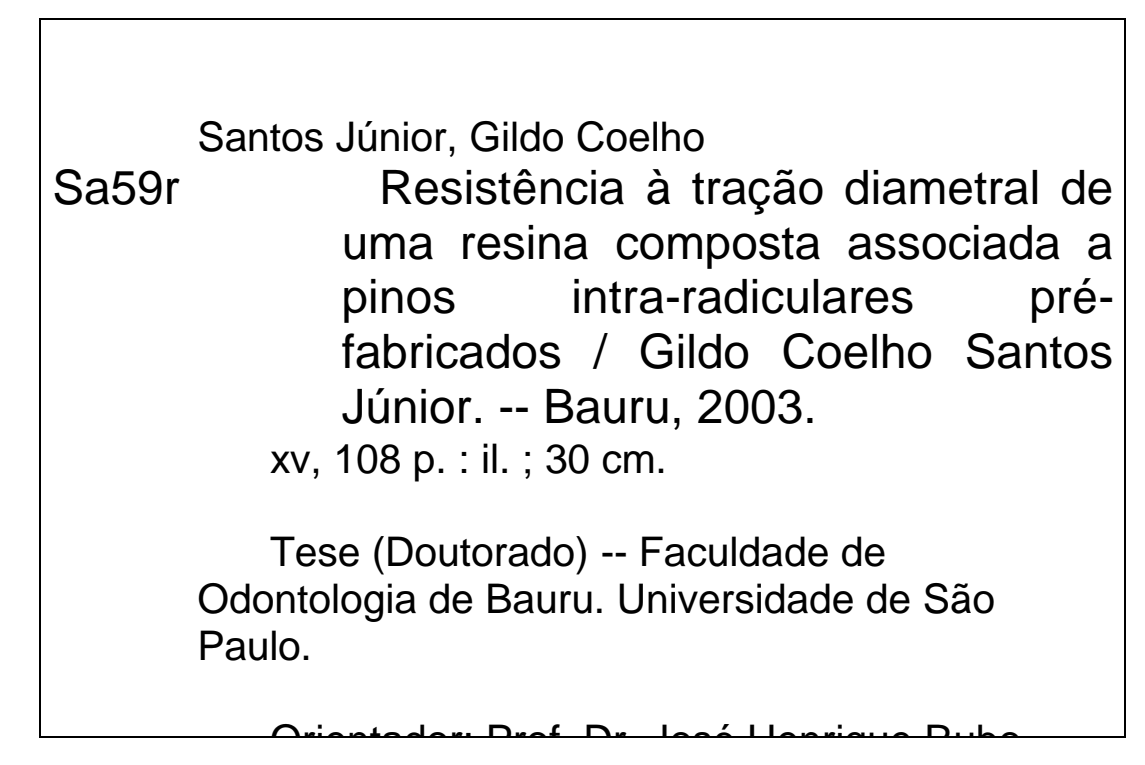

Autorizo exclusivamente para fins acadêmicos e científicos, a reprodução total ou parcial desta tese por processos fotocopiadores e/ou meios eletrônicos.

Assinatura do autor (a):

Data: 


\begin{tabular}{|c|c|}
\hline \multirow[t]{2}{*}{26 de junho de 1963} & Nascimento \\
\hline & Salvador - Bahia \\
\hline \multirow[t]{2}{*}{$1982-1985$} & Curso de Odontologia - Faculdade de Odontologia \\
\hline & Universidade Federal da Bahia \\
\hline $1986-1987$ & $\begin{array}{l}\text { Cursos de Atualização em Prótese Fixa } \\
\text { e em Oclusão pela Profis, Bauru, SP }\end{array}$ \\
\hline $1987-1988$ & $\begin{array}{l}\text { Curso de Aperfeiçoamento em Periodontia } \\
\text { pela Profis, Bauru, SP }\end{array}$ \\
\hline 1992 & $\begin{array}{l}\text { Professor Auxiliar do Curso de Odontologia da } \\
\text { Universidade Federal da Bahia }\end{array}$ \\
\hline $1993-1994$ & $\begin{array}{l}\text { Curso de atualização em Modern Implant Dentistry, } \\
\text { University of Miami, USA }\end{array}$ \\
\hline 1995 & Curso Básico de Inglês, UEC, Salvador, BA \\
\hline $1995-1997$ & $\begin{array}{l}\text { Curso de Especialização em Implantes Odontológicos } \\
\text { pela Faculdade de Odontologia de Bauru, USP }\end{array}$ \\
\hline $1995-1999$ & $\begin{array}{l}\text { Curso de Pós-Graduação em Clínicas Odontológicas, } \\
\text { em nível de Mestrado, na Fac. de Odontologia, UFBA }\end{array}$ \\
\hline 2000 & $\begin{array}{l}\text { Professor Assistente do Curso de Odontologia da } \\
\text { Universidade Federal da Bahia }\end{array}$ \\
\hline 2000 & $\begin{array}{l}\text { Curso de Pós-Graduação em Inglês pelo CCAA, } \\
\text { Salvador, BA }\end{array}$ \\
\hline $2000-2003$ & $\begin{array}{l}\text { Curso de Pós-Graduação em Reabilitação Oral, em nível } \\
\text { de Doutorado, na F.O. de Bauru, USP / F.O. da } \\
\text { Universidade de Toronto, Canadá (Doutorado Sanduíche) }\end{array}$ \\
\hline \multirow[t]{2}{*}{ Associações } & $\begin{array}{c}\text { ABO - Associação Brasileira de Odontologia, } \\
\text { Seção Bahia (Sócio Benemérito) }\end{array}$ \\
\hline & SBPqO - Sociedade Brasileira de Pesq. Odontológica \\
\hline
\end{tabular}


Dedico este trabalho

A Deus,

aos meus pais que com amor, carinho e exemplo de vida, são responsáveis pela minha formação,

à minha amada esposa, companheira de sonhos e realizações, pelo irrestrito apoio em todos os momentos de nossa vida. 
Ao meu Orientador e amigo, Prof. Dr. José Henrique Rubo, pelo estímulo e apoio dado em todas as iniciativas de trabalho, pela imensa oportunidade de crescimento profissional e pessoal, tanto pela convivência diária quanto pela influência decisiva em na obtenção do estágio no Canadá e, acima de tudo, por sua amizade.

Ao Prof. Dr. Luiz Fernando Pegoraro, Vice-Diretor da Faculdade de Odontologia de Bauru, USP e coordenador do curso de Doutorado em Reabilitação Oral, pelos ensinamentos e total apoio e incentivo na busca deste sonho.

À Profa . Dra . Maria Fidela de Lima Navarro, Diretora da. Faculdade de Odontologia de Bauru, USP, pelo exemplo de dedicação e trabalho na vida acadêmica.

Ao Prof. Dr. José Carlos Pereira, Coordenador da Pós-Graduação, pelo apoio e incentivo na realização deste projeto.

Aos Profs. e amigos Omar El-Mowafy, Doroty McComb e Laura Tam, da Faculty of Dentistry, University of Toronto, Canadá, pelo carinho com que nos receberam em Toronto. 
À colega e amiga Prof $\stackrel{a}{\text { a }}$ Ceres Mendonça Fontes, orientadora no Mestrado em Clínicas Odontológicas na FOUFBA, pela amizade, orientação na vida acadêmica e pela oportunidade que me foi dada ao ser conduzido à docência na FOUFBA.

Ao colega e amigo Prof. Dr. Edmar Santana, Diretor da Faculdade de Odontologia da UFBA, que pelo seu empenho e dedicação, iniciou e coordenou o Mestrado em Clínicas Odontológicas na FOUFBA, gerando o estímulo e oportunidade de crescimento.

À Aparecida Maria Cordeiro Marques, Chefe do Departamento de Odontologia Restauradora da UFBA aos colegas do Departamento que, em assumindo parte de minhas funções como Professor, permitiram a realização deste projeto de qualificação.

Aos Profs. do Departamento de Prótese da FOB-USP, Profs. Drs. Accácio; Gerson; Paulo Martins; Paulo Conti; Carlos; Wellington, Renato, Lucimar e Milton, pela calorosa acolhida, compreensão, preciosos ensinamentos e exemplo de dedicação à vida acadêmica.

Aos meus colegas e amigos do curso de Doutorado em Reabilitação Oral, Juliano; Carlos; Nelson; Vinícius; Stefânia; Rudys e Anuar pela maneira afetiva como me acolheram na turma e em especial a Willian Barnabé que se revelou grande amigo e companheiro nesta trajetória. 
Às funcionárias do Departamento de Prótese, Edna; Cláudia e Débora pelo carinho e afeição.

Aos funcionários da Pós-Graduação, Giane; Aurélio, Letícia, Ana Maria, Cleusa e Solange, pela dedicação, amizade e pronto auxílio.

Às funcionárias da Biblioteca, Valéria e Sônia, pela ajuda nas correções de formatação, não só desta Tese como de todos os trabalhos preparados durante o curso de Doutorado.

Aos amigos Profs. Drs. Reinaldo Todescan e Eliseu Pascon pela calorosa recepção, tornando ainda mais agradável o tempo em que passei em Toronto.

À Ivoclar-Vivadent nas pessoas de Herbert Mendes e Éderson Pereira pelo fornecimento de parte do material utilizado nesta pesquisa.

A todos os amigos e familiares que me incentivaram a apoiaram durante este período longe de casa.

A todos que direta ou indiretamente contribuíram para a execução deste trabalho. 
Agradeço em especial:

À Universidade Federal da Bahia pelo incentivo à capacitação docente.

À Capes pelo auxílio a pesquisa concedido através do processo BEX $1246 / 01-1$. 
LISTA DE FIGURAS

LISTA DE TABELAS

RESUMO

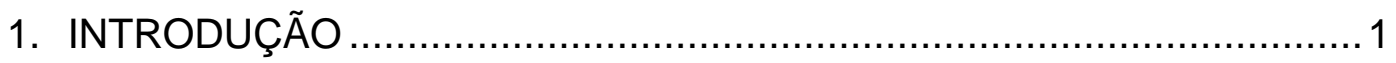

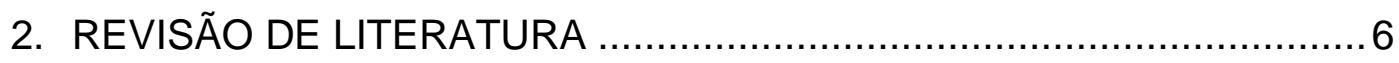

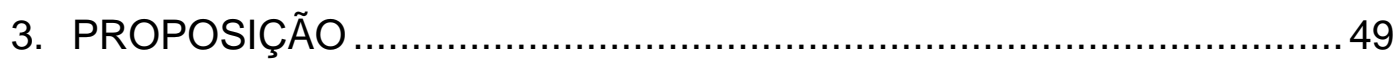

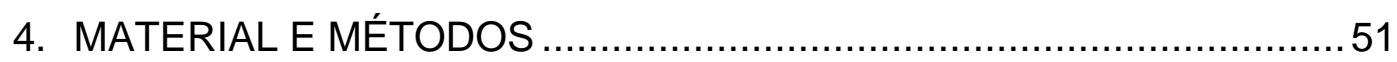

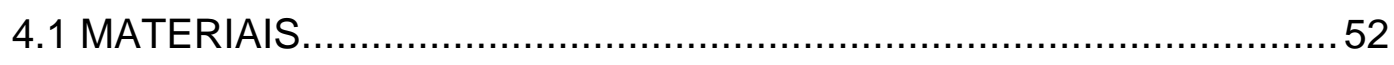

4.1.1 Pinos Intra-Radiculares Pré-Fabricados ………........................... 52

4.1.2 Material de preenchimento coronário.............................................53

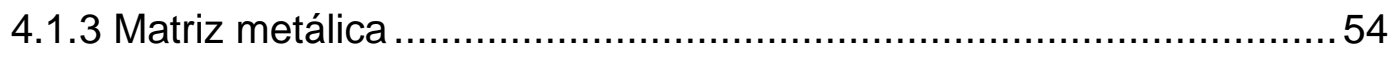

4.2 INSTRUMENTOS, DISPOSITIVOS E MÉTODO DE PESQUISA .........55

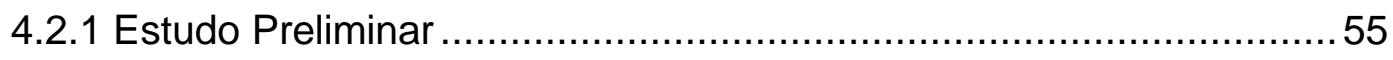

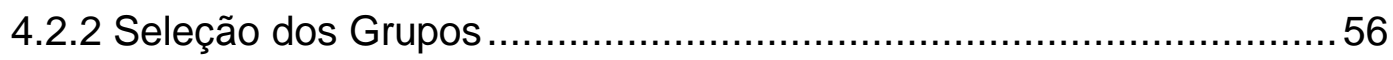

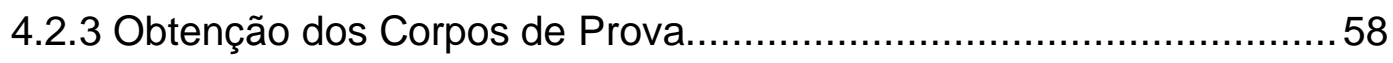

4.2.4 Ensaios de Tração Diametral .........................................................60

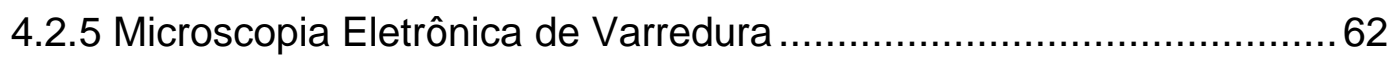

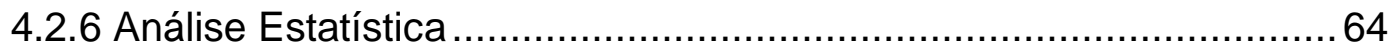

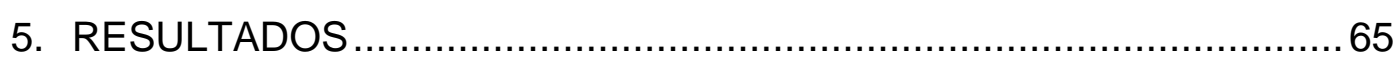

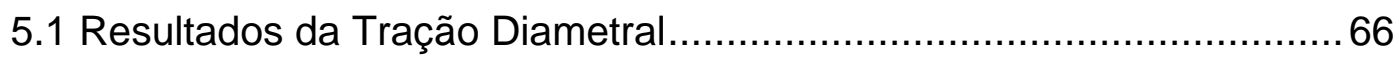

5.2 Resultados da Microscopia Eletrônica de Varredura ..............................69 


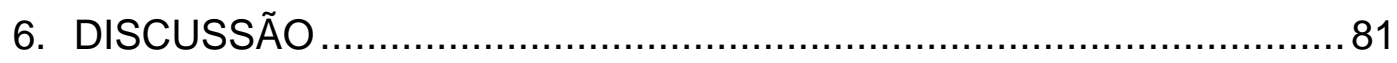

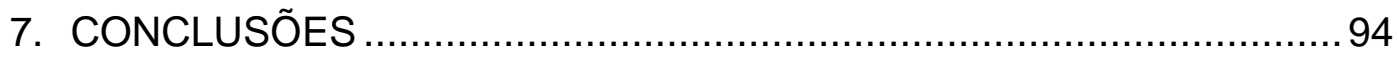

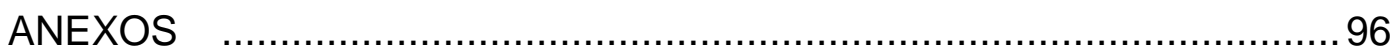

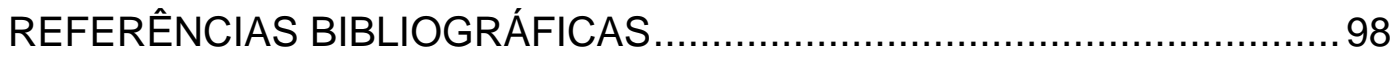

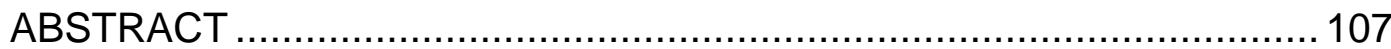


Figura 4.1 - Quadro com as especificações dos pinos utilizados 52

Figura 4.2 - Pinos pré-fabricados. A- Vectris-Post; B- Fibre-Post; CÆstheti-Plus; D- Light-Post; E- Dentorama e F- ParaPost. 53

Figura 4.3 - Quadro com a especificação do material de reconstrução coronária. 54

Figura 4.4 -Matriz metálica (A) com as porções inferior (B) e superior (C). 55

Figura 4.5 - Amostras dos grupos de estudo. G1- Tetric Ceram; G2Vectris-Post; G3- Fiber-Post; G4- Æstheti-Plus; G5- Light-Post; G6Dentorama e G7- Para-Post. 57

Figura 4.6 - Preparação de um corpo de prova. A- Aplicação do silano; B- Aplicação do agente de união; C- Posicionamento do pino na matriz e D- Fotopolimerização da amostra..

Figura 4.7 - Máquina de ensaio Instron 8501

Figura 4.8 - Amostra antes do ensaio mecânico (A) e após o ensaio mecânico (B). 61

Figura 4.9 - Identificação dos corpos de prova. 62 Figura 4.10 - Amostras preparadas para microscopia eletrônica de varredura (A) e microscópio eletrônico de varredura Hytachi S2500 torre de vácuo e plataforma de comando $(\mathrm{B})$ 63 
Figura 5.1 - Gráfico dos valores médios da resistência à tração diametral dos grupos em ordem decrescente e comparação estatística entre grupos. Os valores ligados por barras representam grupos sem diferença estatística.

69

Figura 5.2 - Fotomicrografia do pino representante do Grupo 2. No sentido horário: Superfície do pino; padrão de fratura; aumento de 100 $\mathrm{X}$ e aumento de $500 \mathrm{X}$

Figura 5.3 - Fotomicrografia do pino representante do Grupo 3. No sentido horário: Superfície do pino; padrão de fratura; aumento de 100 $\mathrm{X}$ e aumento de $500 \mathrm{X}$.

Figura 5.4 - Fotomicrografia do pino representante do Grupo 42. No sentido horário: Superfície do pino; padrão de fratura; aumento de 100 $\mathrm{X}$ e aumento de $500 \mathrm{X}$

Figura 5.5 - Fotomicrografia do pino representante do Grupo 5. No sentido horário: Superfície do pino; padrão de fratura; aumento de 100 $\mathrm{X}$ e aumento de $500 \mathrm{X}$

Figura 5.6 - Fotomicrografia do pino representante do Grupo 6. No sentido horário: Superfície do pino; padrão de fratura; aumento de 100 $\mathrm{X}$ e aumento de $500 \mathrm{X}$.

Figura 5.7 - Fotomicrografia do pino representante do Grupo 7. No sentido horário: Superfície do pino; padrão de fratura; aumento de 100 $X$ e aumento de $500 \mathrm{X}$ 
Figura 5.8 - Fotomicrografia do pino representante do Grupo 2. Espécimes com maior e menor valor, respectivamente. Aumento de $1000 \mathrm{X}$.

Figura 5.9 - Fotomicrografia do pino representante do Grupo 3. Espécimes com maior e menor valor, respectivamente. Aumento de $1000 \mathrm{X}$.

Figura 5.10 - Fotomicrografia do pino representante do Grupo 4. Espécimes com maior e menor valor, respectivamente. Aumento de $1000 \mathrm{X}$.

Figura 5.11 - Fotomicrografia do pino representante do Grupo 5. Espécimes com maior e menor valor, respectivamente. Aumento de $1000 \mathrm{X}$.

Figura 5.12 - Fotomicrografia do pino representante do Grupo 6. Espécimes com maior e menor valor, respectivamente. Aumento de $1000 \mathrm{X}$.

Figura 5.13 - Fotomicrografia do pino representante do Grupo 7. Espécimes com maior e menor valor, respectivamente. Aumento de $1000 \mathrm{X}$. 
Tabela 5.1 - Médias e desvio padrão dos resultados de resistência à tração diametral (MPa) dos grupos de 1 a $7 \cdot n=10$ 66

Tabela 5.2 - Dados do teste estatístico de análise de variância a um critério obtidos dos ensaios de tração diametral. 67 Tabela 5.3 - Teste de Tukey para comparação múltipla entre os grupos testados. Nível de significância $=5,00 \%$. 68 
W.

462

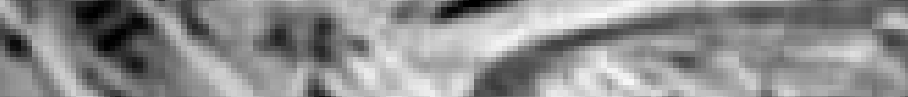

W.

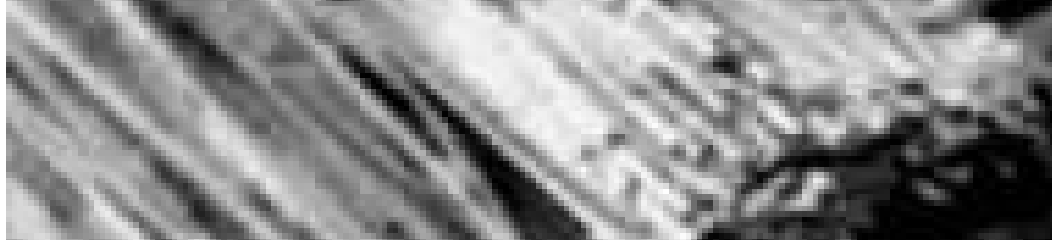

WhW Whaters

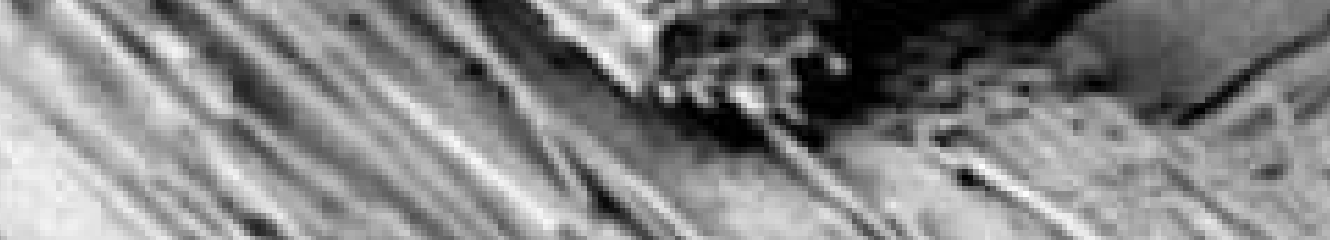

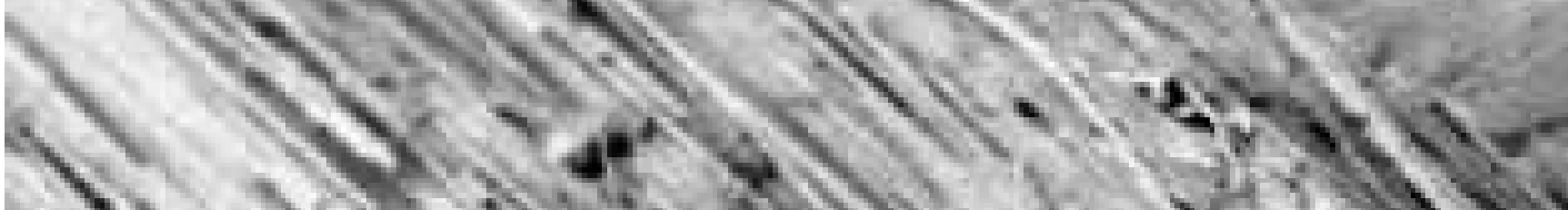

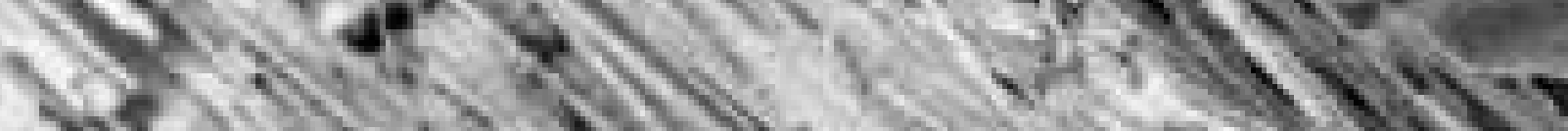

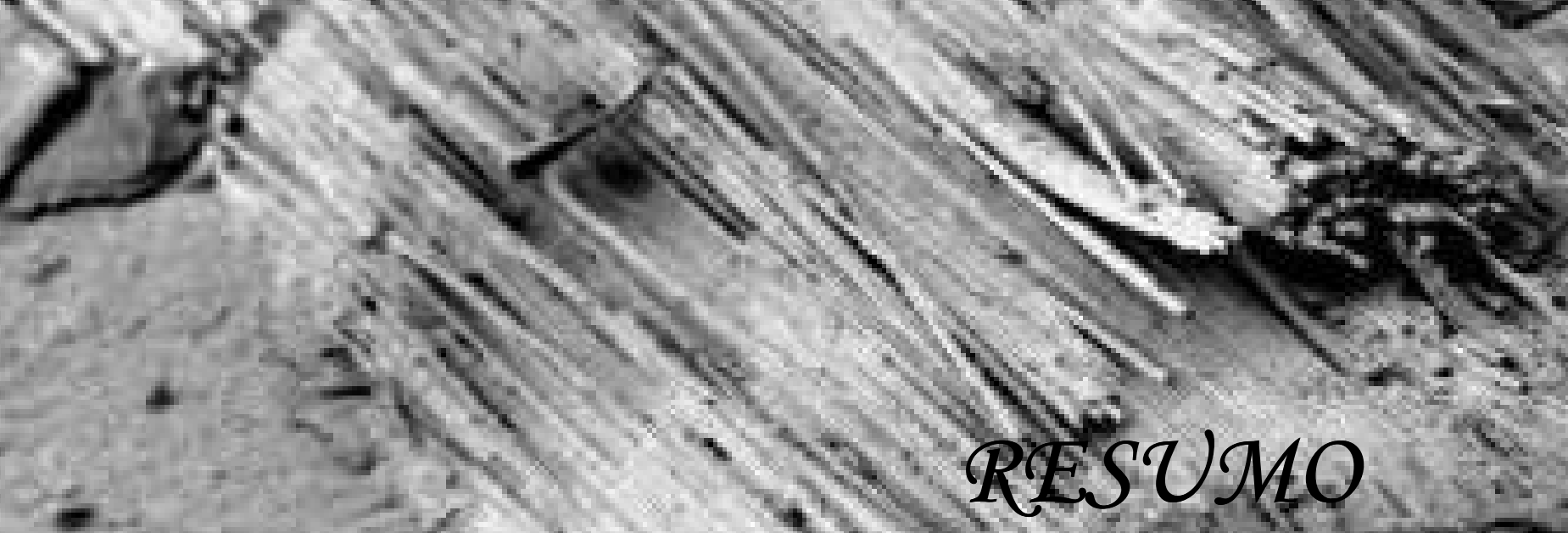

$=\quad 2 \quad$ RTSUMO

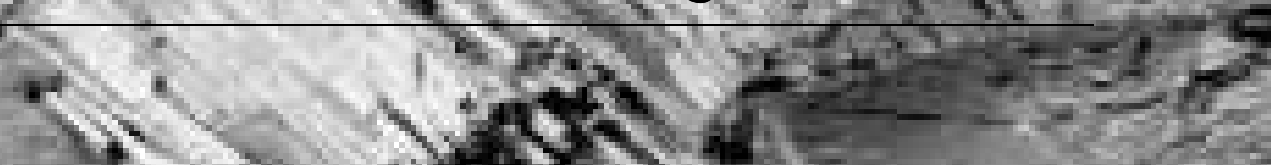

Bis

$\log _{9}$ is:

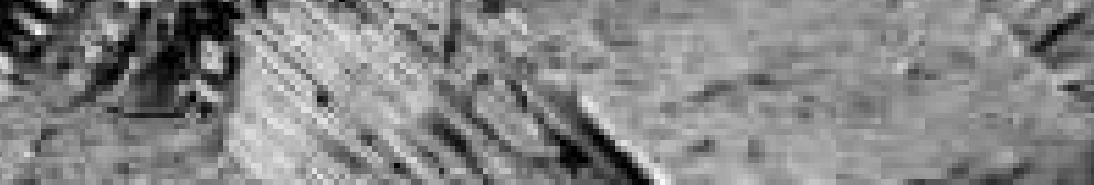

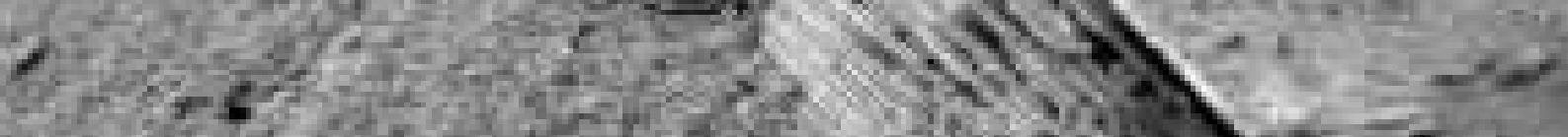

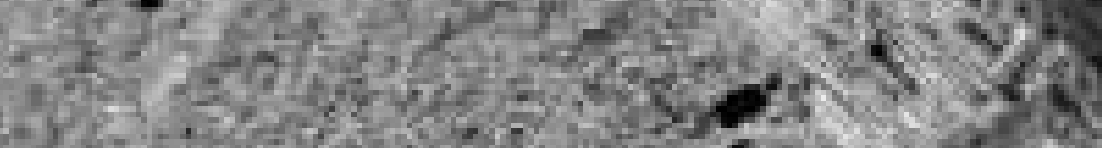




\section{RESUMO}

Este estudo teve a finalidade de verificar influência de diferentes tipos de pinos intra-radiculares sobre a resistência à fratura de um material restaurador coronário, utilizando o teste de tração diametral.

Foram confeccionados 70 corpos de prova divididos em 7 grupos: G1. Compósito (Tetric Ceram - Ivoclar/Vivadent) (Grupo Controle); G2. Compósito e pino VectrisPost (Ivoclar/Vivadent); G3. Compósito e pino Fiber-Post (Jeneric/Pentron); G4. Compósito e pino ÆEstheti-Plus (Bisco); G5. Compósito e pino Light-Post (Bisco); G6. Compósito e pino Dentorama (Svenska) e G7. Compósito e pino ParaPost (Còltene/Whaledent). Todos os grupos foram submetidos ao ensaio de tração diametral em uma máquina de ensaios Instron, modelo 8501, até a fratura. A média dos grupos em MPa foi: G 1- 49,64 (3,36); G 2- 29,77 (3,36); G 3- 31,9 (2,39); G 4- 28,92 (2,20); G 5- 34,26 (3,37); G 6$33,45(2,46)$ e G 7- 27,90 (2,40).

A análise estatística dos dados nos permitiu concluir que: os pinos utilizados não reforçaram a resina composta; os pinos Light-Post, Dentorama e Fiber-Post apresentaram os melhores valores de adesividade ao material de reconstrução coronária e que o pino metálico ParaPost apresentou o menor valor de adesão à resina de reconstrução coronal. 
W.

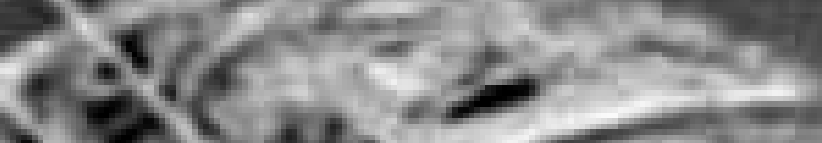

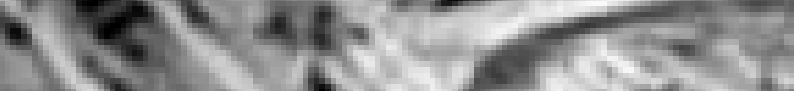

$4 \cdot 2 \mathrm{~s}+2$

1 - Nes?

N visis.

W N vere

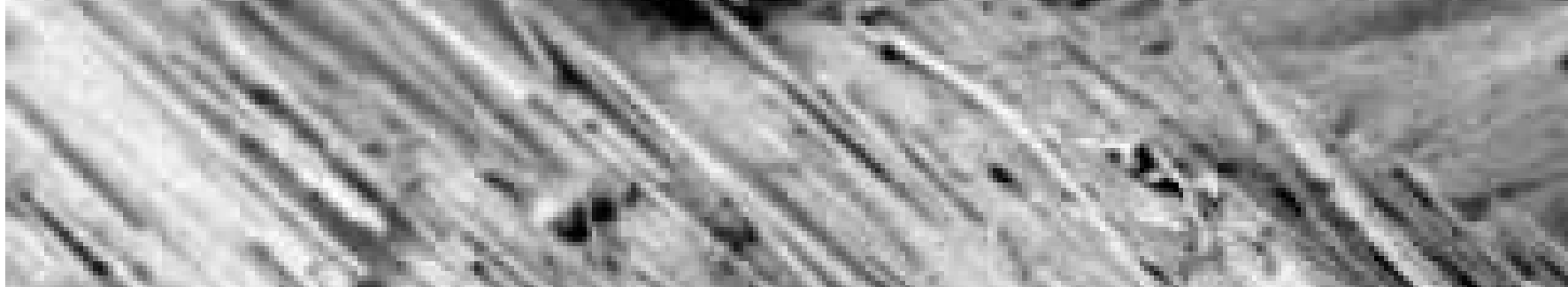

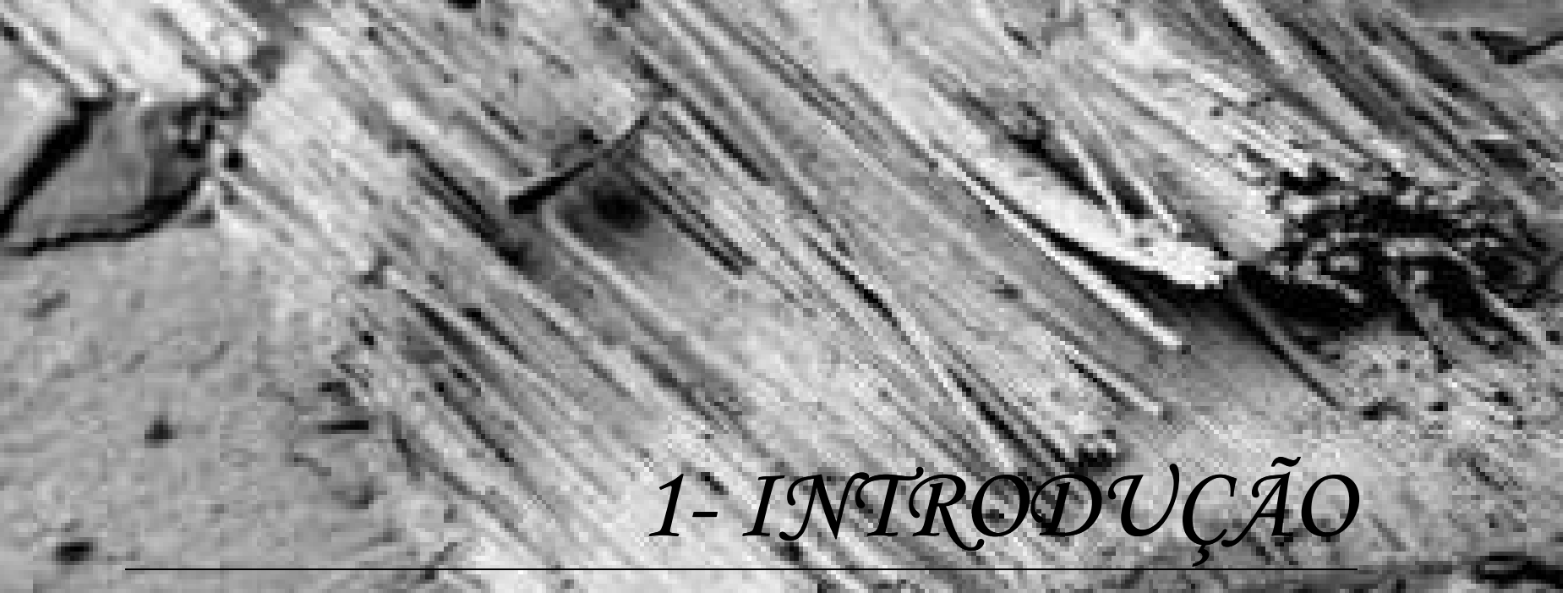

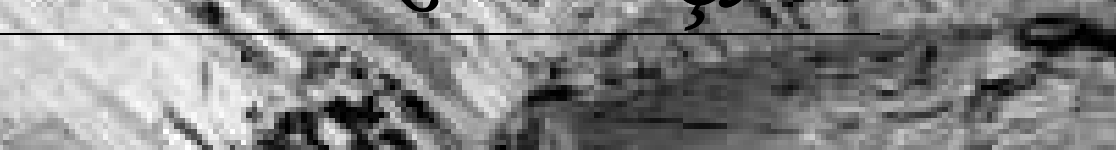

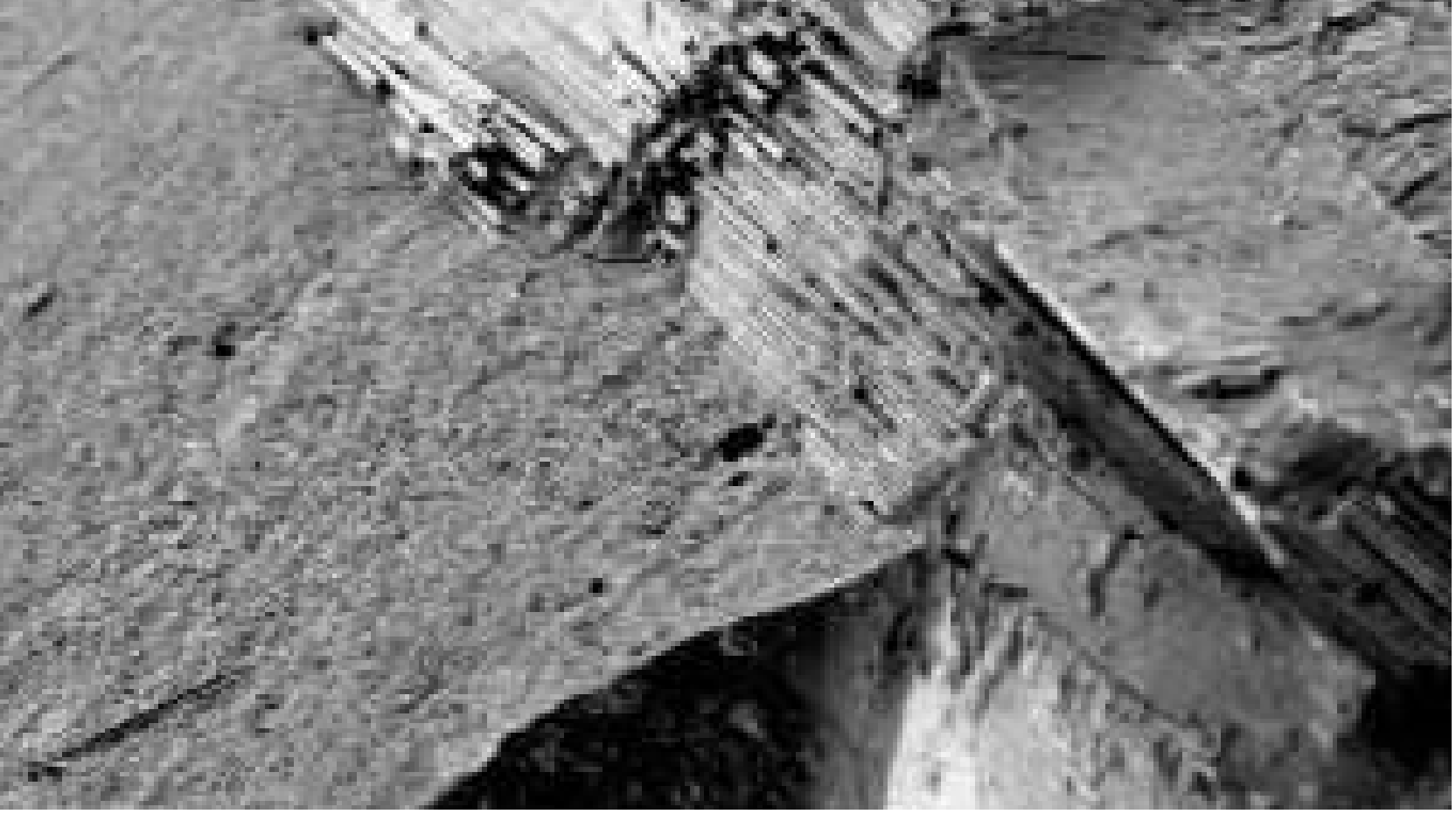




\section{1- INTRODUÇÃO}

Ao longo dos anos a Odontologia vem buscando através de pesquisas, alternativas restauradoras a fim de restabelecer as condições fisiológicas da mastigação e devolver a estética perdida, desenvolvendo soluções cada vez mais duradouras.

O desenvolvimento de técnicas adesivas permitiu grandes avanços no campo da Odontologia restauradora beneficiando os pacientes com tratamentos mais conservadores. Apesar dos conceitos modernos de prevenção, não é rara a necessidade de tratamento endodôntico em dentes que sofreram traumas ou destruição por cárie e reabilitação protética de sua estética e função. Para que estas unidades venham a ser restauradas, freqüentemente a reconstrução coronária deve ser realizada para incrementar a retenção final da peça protética.

A forma mais popular de se recuperar dentes com extensa destruição é utilizando núcleos metálicos fundidos, particularmente em unidades com canais elípticos ou largos conforme relataram ROSENSTIEL; LAND; HOLLOWAY ${ }^{49}$ (1997) e MONDELLI ${ }^{42}$ (1998). Outra maneira de se reconstruir a porção coronária é com o auxílio de pinos intra-radiculares pré-fabricados que são cimentados no conduto radicular e servem de reforço estrutural para a resina que irá restaurar a porção coronária. 
Segundo SANTOS JR; FONTES ${ }^{51}$ (1999) a vantagem dos pinos préfabricados sobre os núcleos fundidos é a praticidade clínica e eliminação da etapa laboratorial. A melhor forma de cimentação destes pinos tem sido estudada largamente na Odontologia, sendo a fixação com cimentos resinosos a forma normalmente indicada pelos fabricantes.

A exigência estética e o surgimento das coroas livres de metal levaram a novos avanços na restauração de dentes tratados endodonticamente através de pinos que simulam a dentina permitindo um efeito mais natural à restauração final. Os núcleos metálicos não se prestam a esta função, pois causam uma aparência artificial às coroas sem metal devido à translucidez destas. Como uma forma de se minimizar este problema, SANTOS JR; SANTOS; BASTOS ${ }^{52}$ em 2000 preconizaram o uso de agentes opacificadores para mascarar o efeito do metal quando do uso de pinos pré-fabricados com reconstrução em resina da porção coronária.

Segundo KOUTAYAS; KERN ${ }^{35}$ (1999) e FERRARI et al ${ }^{19}$ (2000) diferentes técnicas de recobrimento de pinos têm sido propostas para se conseguir o mascaramento necessário quando restaurações confeccionadas em cerâmica pura são cimentadas a dentes com núcleos metálicos. LOPES et $\mathrm{al}^{37}$ (2001) afirmaram, entretanto, que estes métodos não resolvem por completo o problema porque os pinos metálicos continuam podendo refletir através das áreas cervical e radicular. FRADEANI; AQUILANO; BARDUCCI ${ }^{21}$ em 1999 já ressaltavam que a transmissão de luz por parte dos pinos é de fundamental importância na criação de um efeito estético. 
As propriedades estéticas dos materiais usados nas bases para restaurações protéticas tem tido uma maior atenção por parte dos pesquisadores e dos clínicos devido ao aumento do uso de próteses sem metal na região anterior. Para se corrigir o problema estético dos pinos metálicos, foram desenvolvidos pinos, denominados de estéticos, à base de zircônia ou reforçados por fibras, cuja coloração permite que a reconstrução coronária simule a dentina, sem a necessidade de aplicação de opacificadores. Estes pinos têm transparência similar à da dentina, apresentam cor de dente universal e são altamente translúcidas, permitindo uma melhor estética nas restaurações de cerâmica pura ou resina. Porém, os pinos cerâmicos são extremamente duros e resistentes não apresentando um comportamento plástico.

Os avanços tecnológicos também têm sido direcionados para a obtenção de um pino que apresente módulo de elasticidade semelhante ao da dentina que é de 14.2 GigaPascal (GPa). De acordo com os fabricantes, os pinos reforçados por fibra apresentam de 1 a 2 vezes este valor. Em contraste com estes materiais, o ParaPost, um pino metálico pré-fabricado, apresenta de 8 a 9 vezes o valor do módulo de elasticidade da dentina e os pinos cerâmicos 15 vezes. Segundo CORMIER; BURNS; MOON ${ }^{11}$ em 2001, a similaridade em elasticidade dos materiais restauradores e a dentina pode permitir a flexão dos pinos imitando a flexão do dente.

Com o lançamento no mercado odontológico de novos pinos estéticos de resina reforçada, procuramos avaliar o aumento da resistência que estes 
pinos propiciam ao material restaurador na técnica direta de reconstrução da porção coronária com resina composta e como eles interagem com este material, através de ensaios mecânicos e avaliação dos tipos de fratura em microscopia eletrônica de varredura uma vez que, ao contrário dos núcleos fundidos, em que as porções coronária e radicular formam uma peça única, as reconstruções são formadas por dois elementos e é imperativo que os materiais envolvidos apresentem uma boa interação, proporcionando resistência à reconstrução coronária que suportará a coroa. 
W.

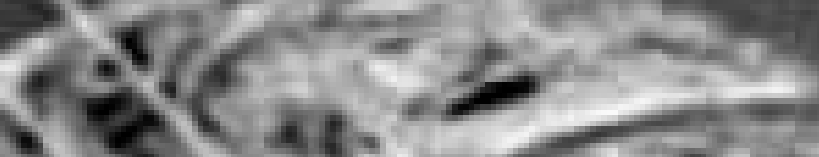

$$
4 \text { कासे }
$$

1 .

414 and

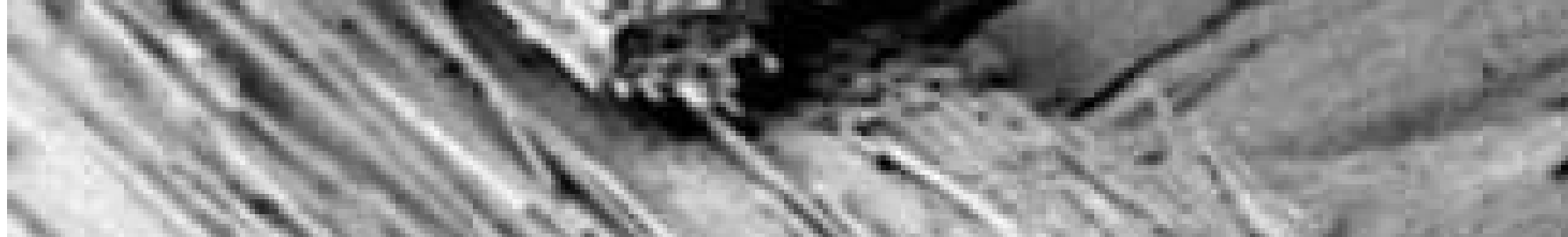

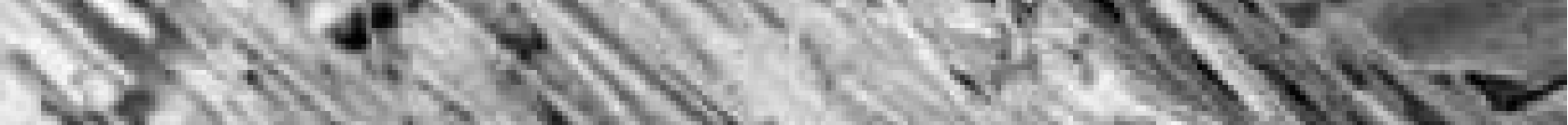
$2 \mathrm{x}, 1$

9

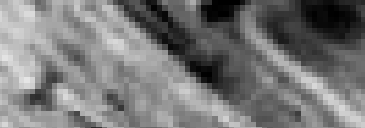

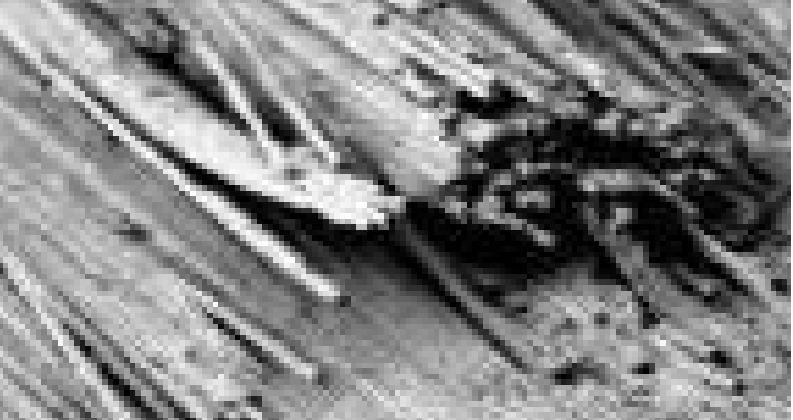

- IN 1 .

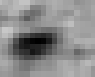
$x$ $+4=1$ 4.

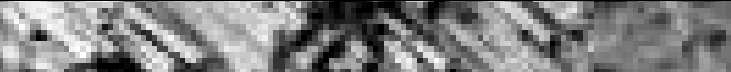
$30 y \sin _{2}=$ SIFER TTURA

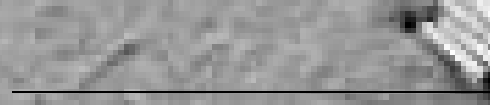
Q $y$

cingeria: $x \rightarrow 3$

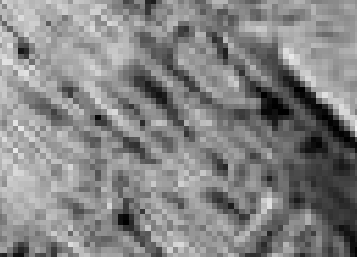




\section{2- REVISÃO DE LITERATURA}

Vários métodos de obtenção de pinos vêm sendo desenvolvidos ao longo dos anos. Por volta de 1770, PIERRE FAUCHARD (MONDELLI' $\left.{ }^{42}, 1998\right)$ descreveu a utilização de coroas com retentores intra-coronários. Com a evolução da endodontia, a restauração de dentes tratados endodonticamente com núcleos metálicos fundidos ganhou popularidade e os pesquisadores começaram a estudar o melhor formato para os pinos, a técnica de confecção e a indicação destes.

No ano de 1977, HENRY ${ }^{24}$, usando estudo fotoelástico de pinos com diversos comprimentos e formatos, concluiu que o pino paralelo distribui melhor as forças e o pino convencional em forma de cunha as concentra na região apical e coronal quando submetido a cargas fora do longo eixo do dente. Ainda neste estudo, condenou o uso de pinos rosqueáveis por serem estes os que apresentaram os piores resultados, com o aumento de tensão nas regiões das roscas podendo causar fratura.

Também em 1977, KANTOR; PINES ${ }^{32}$, estudando várias formas de restaurar unidades com canais tratados concluíram que o reforço com um pino metálico pré-fabricado colocado no conduto de uma unidade com bastante estrutura dental íntegra, dobra a resistência à fratura em comparação ao grupo controle. Sugere ainda que, para as unidades com maior perda tecidual utilizadas como suporte de prótese parcial fixa, um núcleo metálico fundido seja 
a melhor alternativa para a restauração, pois o conjunto pino pré-fabricado e resina composta não apresenta bons resultados para suporte destas próteses.

No ano de 1980, STANDLEE et $\mathrm{al}^{55}$, trabalharam com análise fotoelástica utilizando o sistema Radix Anchor (Star Dental Mfg.Co.) com comprimentos variáveis (5 e 8 milímetros [mm]) e diâmetros variáveis $(1,65$ e $1,85 \mathrm{~mm})$. Concluíram que quanto mais profundo e largo for o pino mais retenção apresentará, porém, para cada incremento conseguido para a retenção, mais se aumenta o risco de fratura. Afirmaram ainda que pinos fundidos com o formato cônico apresentam uma menor retenção e uma alta concentração de esforço na porção coronária. Os valores encontrados pelos autores para se remover os pinos Radix foram de 72 +/- 11 kilos (kg) para 1,85/8 mm, enquanto os pinos cônicos cimentados apresentaram uma força necessária para o deslocamento de $15 \mathrm{~kg}$ para o mesmo tamanho e largura do pino.

Em 1989, KWIATKOWSKI; GELLER ${ }^{36}$ descreveram o uso de pinos de cerâmica fabricados pelo sistema Dicor (Dentsply). Afirmaram os autores que o uso de pinos cerâmicos em conjunto com coroas de cerâmica pura permitem uma melhor transmissão de luz às estruturas adjacentes causando um melhor efeito estético. Comentaram ainda que, o coeficiente de expansão térmica destes pinos se assemelha ao da dentina minimizando o estresse na interface radicular de dentina com o cimento resinoso.

Também em 1989, HUNTER; FEIGLIN; WILLIAMS ${ }^{29}$, avaliaram incisivos centrais superiores medindo o estresse gerado no preparo e na cimentação do 
pino. Observaram que o alargamento do conduto aumentou o estresse cervical, enquanto a colocação deste diminuía este estresse, e viram que o comprimento foi mais importante na obtenção de um menor estresse do que o diâmetro. Ainda afirmaram que a colocação do pino além dos dois terços do comprimento da raiz não diminuía o estresse cervical, mas, normalmente, aumentava o estresse gerado na região apical. Também viram que o aumento do comprimento além dos dois terços do comprimento da raiz não resultou em um aumento na retenção.

Em 1990, CURY; COSTA $^{14}$ relataram que existem diversas formas de restaurar um dente tratado endodonticamente dependendo da sua destruição coronária. Quando indicado o uso de núcleos metálicos fundidos, devem-se levar em consideração fatores como comprimento, configuração geométrica, rugosidade superficial e tipo de metal, observando-se um comprimento mínimo de $2 / 3$ do canal ou 1/2 da altura óssea remanescente e preservando 3 a $5 \mathrm{~mm}$ de material obturador no periápice. Para os pinos pré-fabricados, recomendaram a não utilização dos pinos rosqueáveis a menos que o canal seja curto ou com curvatura e que sua colocação seja em dentes com terapia endodôntica recente, uma vez que a desvitalização leva a uma dentina friável.

COHEN et $\mathrm{al}^{7}$ em 1992 pesquisaram a resistência à compressão e à tração diametral de materiais de preenchimento coronário reforçados com titânio, comparando com outros materiais restauradores. Usaram 9 grupos com 10 amostras cada, divididos de acordo com os materiais (1- Ti-Core, resina composta, EDS; 2- Flexi-Flow, cimento reforçado com titânio, EDS; 3- Flexi- 
Flow, cimento, EDS; 4- Den-Mate, resina composta, Den-Mat Corporation; 5Ketac-Silver, ionômero de vidro, ESPE; 6- Fleck, cimento de fosfato de zinco, Mizzy; 7- Durelon, ESPE; 8- Ketac-Cem, cimento de ionômero de vidro , ESPE e 9- GC Miracle Mix, ionômero de vidro, GC). Todos os espécimes foram preparados seguindo as instruções dos fabricantes e com a norma número 27 da ADA (American Dental Association) para materiais restauradores de resina. Os resultados encontrados demonstraram que o cimento Flexi-Flow reforçado por titânio e a resina Ti-Core apresentaram os mais elevados valores de resistência à compressão (41.876 Libras por polegada quadrada [PSI] e 41.131 PSI respectivamente) semelhantes à da dentina (43.100 PSI). Em relação à resistência à tração diametral, novamente a resina Ti-Core e o cimento FlexiFlow reforçado por titânio, apresentaram os maiores valores (5.219 PSI e 4.930 PSI) também próximos ao valor da dentina (6.000 PSI). Os autores concluíram que tanto para o ensaio de compressão quanto para o ensaio de tração diametral, os materiais reforçados por titânio apresentaram um desempenho melhor do que os outros materiais estudados.

No ano de 1994, ASSIF; GORFIL ${ }^{3}$ afirmaram que os esforços empregados para aumentar o comprimento e o diâmetro dos núcleos metálicos fundidos comprometem o prognóstico do dente restaurado. Por esse motivo, ele sugeriu que o seu uso seja apenas indicado quando não houver outro meio de retenção para a restauração coronal. Os autores relataram que os dentes tratados endodonticamente são mais fracos devido a perda de dentina durante a preparação do canal. Também estabeleceram que quando um mínimo de 
$2 \mathrm{~mm}$ de estrutura coronal estiver presente, o prognóstico favorável ao dente aumenta.

EL-MOWAFY; MILENKOVIC ${ }^{18}$, no ano de 1994, trabalharam com 42 dentes divididos em 6 grupos preparando-os para receber um pino ParaPost de $8 \mathrm{~mm}$ de profundidade, cimentando-os com cimento de fosfato de zinco como grupo controle e 5 tipos de cimentos resinosos. Concluíram que os cimentos resinosos necessitaram de uma força maior para serem removidos $(32,9 ; 47$; 34,$9 ; 38,1 ; 45,5$ kilograma-força [kgf]) do que o cimento de fosfato de zinco $(30,1 \mathrm{kgf})$.

Para verificarem a influência da termociclagem na retenção do ParaPost, prepararam mais 7 dentes com técnica semelhante de cimentação de um dos grupos pré-existentes e realizaram 1.000 ciclos. O resultado obtido demonstrou que não houve diferença estatística entre os grupos. Ainda para verificar a influência da profundidade do pino na retenção, prepararam 42 molares, dividiram em 6 grupos sendo $3 \mathrm{com} 5 \mathrm{~mm}$ de profundidade e $3 \mathrm{com} 8 \mathrm{~mm}$ de profundidade. Cimentaram 1 grupo de cada profundidade com um dos 3 cimentos usados anteriormente (Fosfato de zinco, Prisma Universal Bond e AllBond). Novamente não encontraram diferença estatística apesar de os valores terem sido menores para os pinos mais curtos. Os autores concluíram que tanto o Prisma Universal Bond 3/Biomer como o Scotchbond Multi-uso/Resina tiveram um resultado melhor que os outros grupos. As falhas apresentadas em todos os grupos, exceto os fixados com cimento de fosfato de zinco, ocorreram na interface dente/resina. 
Em um estudo longitudinal em 1995, TORBJÖRNER; KARLSSON; ÖDMAN ${ }^{59}$ acompanharam, por 4 a 5 anos, 638 pacientes que receberam 788 pinos divididos em dois grupos: fundidos e pré-fabricados. As falhas apresentadas foram deslocamento, fratura do pino e fratura do dente, sendo em média $2,1 \%$ ao ano. Os pinos pré-fabricados apresentaram melhores resultados que os núcleos fundidos, tendo um insucesso de $8 \%$ contra $15 \%$, respectivamente. As falhas foram classificadas como restauráveis e não restauráveis o que implicava na extração da unidade. Apenas $2 \%$ dos pinos pré-fabricados não puderam ser restaurados, contra 5\% dos núcleos fundidos. A maior incidência de falha ocorreu na maxila, região anterior, em pacientes do sexo masculino e em pacientes com mais de 60 anos. Os autores afirmaram que a causa mais freqüente de insucesso em prótese fixa são as falhas dos núcleos metálicos fundidos que freqüentemente trazem conseqüências fatais. Métodos para incrementar a durabilidade dos dentes tratados endodonticamente incluem a preservação da estrutura dental e se possível evitar a colocação de núcleos metálicos fundidos. Se for necessária a colocação deste, é importante a proteção da raiz com um colar metálico na área marginal da coroa para evitar fratura radicular, fratura ou deslocamento do núcleo.

Em 1996, HOLMES; DIAZ-ARNOLD; LEARY27 avaliaram as condições de esforço a que se submete uma unidade dentária restaurada com pinos intraradiculares, quando submetida a uma força de $10 \mathrm{~kg}$ em um ângulo de $45^{\circ}$. Por meio do Método de Elemento Finito, puderam simular em computador vários 
comprimentos $(8,10,5$ e $13 \mathrm{~mm})$, diâmetros $(1,2,1,4$ e 1,6 mm) e formato (paralelo e cônico). Obtiveram várias conclusões: 1- as forças de tração e compressão ocorrem na região cervical da unidade dentária; 2- o diâmetro do pino pouco influenciou na distribuição das forças de compressão e tração, porém influenciou de forma diretamente proporcional na força de cisalhamento; 3- quanto menor o comprimento do pino maior a situação de esforço; 4- as forças de cisalhamento se concentram na extremidade apical do pino.

Neste mesmo ano, KHAN et $\mathrm{al}^{33}$, selecionaram 60 pré-molares entre 100 dentes extraídos que apresentavam tamanho e forma de canal semelhantes, esterilizados em solução de Cidex por 48 horas (h) e conservados em água destilada estéril. Os canais foram instrumentados até a lima K-file número (n) 35 e obturados com guta percha pela técnica de condensação lateral. Três tipos de pinos pré-fabricados foram usados para este experimento, Cytco Post (L.D. Caulk Co.), Vlock Active (Brasseler USA, Savannah, Ga.) e Flexi-Post (Essential Dental Sistems). Como não havia correlação de tamanho e espessura entre os diversos sistemas, foi utilizado o tamanho mais próximo um do outro. Os dentes foram divididos em 4 grupos de 15 dentes, a saber: 1Cytco; 2- Vlock; 3- Flexi-Post e 4- Controle. Todos foram cortados com broca diamantada na junção esmalte/cemento deixando uma estrutura remanescente de $13 \mathrm{~mm}$, a exceção do grupo 4 que foi cortado deixando $17 \mathrm{~mm}$. Cada grupo recebeu o tratamento indicado pelo fabricante, sendo os pinos pré-fabricados fixados com cimento de fosfato de zinco e um núcleo de preenchimento com amálgama feito para completar a altura de $17 \mathrm{~mm}$ das unidades. $\mathrm{O}$ grupo 4 
apenas recebeu o preenchimento com amálgama na sua porção coronária, com profundidade de $4 \mathrm{~mm}$.

As unidades foram preparadas deixando o término do preparo em dentina sadia fazendo um colar de $1 \mathrm{~mm}$ além do amálgama e as coroas cimentadas com cimento de fosfato de zinco, termocicladas por 100 vezes, variando de 5 graus centígrados $\left(^{\circ} \mathrm{C}\right.$ ) a $50^{\circ} \mathrm{C}$. Os conjuntos foram envolvidos por gesso em um cilindro até $2,5 \mathrm{~mm}$ abaixo da restauração. Uma carga foi aplicada em uma máquina universal Instron de testes num ângulo de $45^{\circ}$ na face vestibular. Todos os grupos apresentaram índice de fraturas semelhantes o que levou os autores a concluir que os tipos de pino utilizados não influenciam na fratura das unidades dentais e nem colaboram para o aumento de resistência das raízes. Isto significa que, se 0 dente tratado endodonticamente possuir estrutura dental remanescente suficiente, não se faz necessária a colocação de pino intra-radicular para aumentar sua resistência.

Ainda no ano de 1996, STEGAROIU et $\mathrm{al}^{56}$ investigaram a influência da carga mastigatória sobre dentes restaurados com pinos pré-fabricados e com núcleos fundidos, utilizando 40 incisivos anteriores superiores extraídos sem cárie. Estes dentes foram seccionados na porção mais apical da junção cemento/esmalte e tiveram seus canais tratados endodonticamente. Os dentes foram divididos em 4 grupos: 1 - restaurados com pino pré-fabricado e resina sem serem submetidos à carga; 2 - restaurados com pino pré-fabricado e resina submetidos à carga; 3 - restaurados com núcleo fundido sem serem submetidos à carga e 4 - restaurados com núcleo fundido submetidos à carga. 
Os grupos 2 e 4 foram submetidos a 175.000 ciclos de carga a $10 \mathrm{~kg}$ de pressão aplicados na face lingual num ângulo de $45^{\circ}$. Todos os grupos, após os referidos tratamentos, foram levados à máquina de ensaio universal para realizar o teste de tração. O grupo 2 (restaurados com pino pré-fabricado e resina e submetidos à carga) apresentou os mais baixos valores do teste e os dentes tratados com núcleos fundidos não apresentaram variação na retenção entre os grupos com e sem carga. Concluíram os autores que, se o canal exigir um preparo mais extenso, um núcleo metálico fundido bem adaptado é o mais indicado, por apresentar uma maior retentividade quando em função.

Em 1996, ISIDOR; ÖDMAN; BRONDUM ${ }^{30}$ utilizaram 14 dentes bovinos preparados para receber pino de fibra de carbono e reconstrução coronária de resina composta, recobertos por coroa total metálica. Sobre esses dentes foi aplicada carga repetitiva de 250 Newtons $(\mathrm{N})$ com freqüência de 2 ciclos por segundo, incidindo em $45^{\circ}$ por 1.000 .000 ciclos. Como os dois primeiros corpos testados não falharam, foi decidido descontinuar os testes com os outros dentes ao se atingir 260.000 ciclos. Nenhum corpo de prova testado apresentou falha. Este trabalho foi comparado com estudo anterior dos autores no qual utilizaram pinos pré-fabricados e núcleos fundidos restaurados por coroas metálicas e utilizando a mesma metodologia. Os piores resultados foram obtidos com os núcleos fundidos que apresentaram fraturas após 270.000 ciclos em todos os corpos de prova, embora os pinos pré-fabricados, que tiveram um resultado significativamente melhor que os fundidos (apenas 2 espécimes falharam), tenham sido inferiores aos de fibra de carbono. Os 
autores afirmaram que os pinos devem apresentar um módulo de elasticidade semelhante ao da dentina (18 Gpa), sendo o de fibra de carbono o que mais se aproxima desse resultado (21 Gpa).

Ainda no ano de 1996, SAUPE; GLUSKIN; RADKE JR ${ }^{53}$ pesquisaram a melhor maneira de se restaurar um dente tratado endodonticamente com extensa destruição do conduto radicular. Utilizaram 40 incisivos centrais superiores em que foram preparados os canais e, posteriormente, tiveram seu lúmem ampliado com broca esférica para simular uma perda de estrutura. Afirmaram os autores que se deve evitar ao máximo remover a estrutura dentinária do canal, pois este fato leva ao enfraquecimento da unidade dental. Caso seja necessário este maior desgaste, um preenchimento do canal com resina fotopolimerizável e posterior confecção do núcleo é a melhor solução, pois além de aumentar a resistência à fratura, este procedimento diminui a aparência escura da raiz pela transparência do metal. Concluíram os autores que o reforço da raiz com resina aumenta em $50 \%$ a resistência à fratura e, com o emprego desta técnica, torna-se dispensável o uso da ferulização da raiz, diminuindo o tempo de trabalho, o desgaste dental e aumentando a estética pela ausência do metal envolvendo o término do preparo.

PURTON; PAYNE ${ }^{46}$ em 1996 investigaram a resistência flexional de pinos de carbono comparada com a de pinos de aço inoxidável e a retenção destes pinos à resina composta utilizada para reconstrução coronal. Trabalharam com os pinos de carbono Composipost (RTD) e ParaPost (Whaledent) e com a resina composta Ti-Core (Essential Dental Systems). 
Para o teste flexional usaram 10 pinos Composipost com 1,4 mm de diâmetro e 10 pinos ParaPost com $1,25 \mathrm{~mm}$, com o resultado calculado pela área transversa dos pinos. Os pinos de carbono apresentaram uma resistência flexional superior estatisticamente aos pinos de aço, $319 \mathrm{GPa}$ contra $213 \mathrm{GPa}$, respectivamente.

Na segunda parte do trabalho, construíram porções cilíndricas de resina composta com auxílio de uma matriz de silicone em pinos de carbono com 1,8 $\mathrm{mm}$ de diâmetro e pinos de aço com 1,5 mm. Secções quadradas de resina foram aplicadas na porção oposta dos pinos para facilitar a instalação na máquina de ensaios. Os teste foram conduzidos a uma velocidade de 10 $\mathrm{mm} /$ minuto com uma força aplicada até a falha do conjunto. Os resultados revelaram que os pinos de aço apresentaram uma resistência à remoção da resina composta estatisticamente superior a dos pinos de carbono $(65,6 \pm 15,6$ $\mathrm{kg}$ contra $38,9 \pm 12,1 \mathrm{~kg}$, respectivamente). Com base nestes resultados os autores concluíram que os pinos de carbono são mais resistentes sob cargas transversas, porém, a resina composta é mais bem retida pelos pinos de aço inoxidável e que a configuração superficial dos pinos influenciaram significantemente no aumento de retenção da resina.

MORGANO ${ }^{43}$, nesse mesmo ano, relatou que os métodos de restauração de dentes tratados endodonticamente são registrados há mais de 100 anos. Com o avanço da endodontia, esta técnica tornou-se cada vez mais popular. Citou o autor que o núcleo metálico não aumenta a resistência à fratura dos dentes, mas, quando protegidos por coroa total com colar cervical 
terminando em $2 \mathrm{~mm}$ de dentina sadia, proporciona uma estabilidade coronoradicular, diminuindo o risco de fraturas. Os casos de falhas são associados a pouca espessura de dentina remanescente nos dentes tratados endodonticamente e à diminuição da sensibilidade pressoreceptiva destes, o que pode levar a alterar a capacidade do paciente de detectar uma sobrecarga mastigatória, contribuindo para uma possível fratura.

O autor recomendou um maior comprimento possível do pino, preservando de 4 a $5 \mathrm{~mm}$ do selamento apical em guta percha, usando instrumento quente para removê-la, conservando ao máximo a estrutura dental, eliminando a possibilidade de perfuração da raiz e, em seguida, usar uma broca de Peeso não maior que a número 2 para remover o cimento restante das paredes dentinárias. Sugeriu ainda, o autor, que sejam reavaliadas as técnicas que preconizam um desgaste maior do canal e que sejam consideradas as técnicas de implantodontia como alternativa a dentes severamente comprometidos.

Analisando a influência do formato da extremidade dos pinos préfabricados, COONEY; CAPUTO; TRABERT ${ }^{13}$ em 1996, compararam 03 sistemas, ParaPost tradicional, ParaPost extremidade afilada e $\mathrm{BCH}$ Post também com extremidade afilada. Os grupos, contendo 5 dentes de um total de 90, variaram em profundidade e espessura, sendo estes pinos fixados com cimento de fosfato de zinco, cobertos com uma fina camada de cera e armazenados em solução salina por 14 dias. Além disto, foram cimentados 
pinos de cada variável em resina fotoelástica para se verificar a distribuição do esforço.

Os dentes foram preparados usando as brocas recomendadas pelos fabricantes, seguindo uma seqüência de incremento de largura. Os resultados demonstraram que os pinos cilíndricos de extremidade reta (ParaPost) apresentaram uma maior retenção tanto para a profundidade de $5 \mathrm{~mm}$ quanto para a profundidade de $8 \mathrm{~mm}$. Estes também tiveram melhor resultado na análise fotoelástica apresentando uma melhor distribuição das forças aplicadas. Os pinos de extremidade afilada apresentaram um efeito de cunha inversamente proporcional à sua largura e profundidade.

Os autores afirmaram que a menor resistência à tração dos pinos de extremidade afilada se deve à falta de paralelismo da extremidade do pino com as paredes do canal, não havendo além disto, ranhuras na extremidade, facilitando o deslocamento do cimento da superfície lisa. Relataram ainda que os resultados dos pinos paralelos de $5 \mathrm{~mm}$ foram semelhantes aos pinos afilados de $8 \mathrm{~mm}$ porque esta diferença de profundidade correspondia ao afilamento do pino, porção que não colabora para retenção. Concluíram que os pinos paralelos são mais eficientes e deveriam ser a primeira escolha clínica, a porção terminal afilada dos pinos pouco contribui para a retenção, os pinos afilados apresentam efeito de cunha e se obtém uma distribuição mais uniforme das forças com um pino paralelo mais largo e profundo.

DIETSCHI; ROMELLI; GORETTI ${ }^{16}$ em 1997 utilizaram um teste in vitro não destrutivo em dentes tratados endodonticamente restaurados com pinos 
pré-fabricados associados a núcleos de preenchimento de resina composta. Trabalharam com os pinos: 1- Komet (Brassler - Titânio); 2- Cerametric (Dentisply - Titânio recoberto por plasma de Óxido de Alumínio); 3Experimental (Dentisply - Zircônia Sinterizada); 4- Composipost (RTD - Fibras de Carbono) e 5- Experimental II (Resina reforçada por Fibras). Usaram 40 incisivos e caninos superiores extraídos por motivos periodontais em que foram tratados os condutos radiculares, restaurados com guta-percha usando um cimento sem eugenol e as coroas cortadas ao nível da junção amelocementária. Os dentes foram divididos aleatoriamente entre os cinco grupos e as raízes foram preparadas para receber os pinos pré-fabricados de acordo com o protocolo de cada fabricante.

Todas as raízes, exceto dos dentes restaurados com o Composipost, foram tratadas com o Self-etching ED Primer (Kuraray) antes da colocação passiva dos pinos com o cimento Panavia 21 (Kuraray) e cobertura com um gel especial de isolamento (Oxyguard - Kuraray) por 5 minutos (min). Os excessos de cimento foram removidos e a dentina remanescente tratada com ácido fosfórico a 37\% (Ultraetch - Ultradent) por 10 segundos (seg) antes da aplicação do Scotchbond Multi-Uso Primer e Adesivo (3M) e polimerização por 40 segundos. A porção coronária foi completada usando uma resina composta híbrida auto-polimerizável (Ti-Core - Essential Dental Systems). Para os dentes restaurados com o Composipost, os condutos radiculares foram tratados com EDTA a $17 \%$ por $30 \mathrm{seg}$, uma camada de adesivo (Sealbond cement etching and resin - RTD) foi aplicada, os pinos cimentados com 
Sealbond Cement (RTD) e a porção coronária restaurada com Ti-Core. Os dentes restaurados foram então levados para o ensaio mecânico de fatiga sendo submetidos a 250.000 ciclos de carga com uma força de $70 \mathrm{~N}$ e uma freqüência de 1,5 Hertz $(\mathrm{Hz})$. Após o ensaio de fadiga os espécimes foram submetidos a 5.000 ciclos térmicos variando de $5^{\circ} \mathrm{C}$ a $55^{\circ} \mathrm{C}$ com tempo de permanência de 1 minuto em cada temperatura. A avaliação das amostras foi feita em microscopia eletrônica de varredura com aumento de $250 \mathrm{X}$ e foi observado que praticamente não houve defeito de adesão entre os pinos e o material restaurador coronário enquanto que para a interface pino/cimento, foi observada uma falha de 10,75\% dos pinos do grupo restaurado com Zircônia.

Os autores puderam concluir que, dentre os grupos estudados, os pinos Experimentais de Zircônia e Experimentais reforçados por Fibras exibiram a maior continuidade de contato na porção coronária e radicular apesar dos dentes restaurados com os pinos de Zircônia terem apresentado fraturas nas raízes e que as propriedades dos pinos de carbono Composipost, que são semelhantes às das estruturas dentais, aparentemente contribuíram para o bom desempenho deste pino.

CHRISTENSEN $^{12}$, em 1998, traçou diretrizes para a escolha da confecção ou não de um pino, afirmando que, se o dente tiver mais do que metade da estrutura coronária íntegra, não é necessária a colocação de pino a menos que o dente seja retentor de prótese fixa ou haja trincas visíveis. Se tiver mais da metade de sua estrutura comprometida, então se recomenda a colocação do pino, sendo o tipo pré-fabricado o mais utilizado atualmente. 
Entre os tipos de pinos pré-fabricados, o sistema ParaPost é o mais utilizado e, quando o dente for receber uma coroa oca de cerâmica, o pino deve ser de cor branca tipo Cerapost ( Brassler USA).

KAKEHASHI et al $^{31}$ em 1998 descreveram o uso de pinos de zircônia associados à cerâmica prensada Cosmo (Ivoclar) e a influência do condicionamento da superfície da zircônia na retenção do material restaurador da porção coronal prensados em formato cilíndrico aos pinos. No grupo controle usaram a técnica de cimentação da porção coronal em vez de usar a cerâmica prensada. Para a obtenção dos corpos de prova usaram uma matriz de teflon na qual eram posicionados os pinos e os padrões de cera eram confeccionados ao redor destes. Os pinos foram preparados num forno Empress EP 500 (Ivoclar) com o uso das pastilhas de cerâmica Empress Cosmo (Ivoclar). O grupo 1 foi o grupo controle (cimentação) e o grupo 3 não receberam tratamento superficial nos pinos, os grupos 2 e 4 tiveram o pino jateado com óxido de alumínio (50 micrometros $[\mu \mathrm{m}])$. Após a obtenção das amostras, os grupos 3 e 4 sofreram ciclagem térmica por 10.000 ciclos. Os pinos foram colocados em um dispositivo de ensaio apoiados apenas pela porção coronal e foram testados recebendo uma carga vertical até que houvesse falha do conjunto. Entre os pinos sem tratamento superficial, os resultados da técnica de prensagem foram significantemente superiores aos da técnica de cimentação (Grupo $3=206 \pm 51 \mathrm{~N}$, Grupo $1=108 \pm 41 \mathrm{~N}$ ). A comparação dos grupos prensados só mostrou diferença estatística entre os grupos 3 e 4 após a ciclagem térmica onde os pinos que receberam tratamento 
superficial (Grupo 4) apresentaram maiores valores no teste de cisalhamento (Grupo $4=292 \pm 65$ N, Grupo $3=206 \pm 51$ N). Os autores concluíram que o uso da técnica de prensagem foi superior à de cimentação permitindo a obtenção de um núcleo fundido inteiramente em cerâmica.

Segundo $\mathrm{AHMAD}^{2}$ em 1998, os núcleos convencionais podem apresentar corrosão causando reações inflamatórias e descoloração no periodonto. O autor sugeriu o uso de pinos de zircônia como forma de se restaurar dentes não vitais relatando que este material apresenta resistência flexional duas vezes superior à da alumina (1400 Newtons por milímetro quadrado $\left.\left[\mathrm{N} / \mathrm{mm}^{2}\right] \times 500 \mathrm{~N} / \mathrm{mm}^{2}\right)$ e semelhante ao carbide $\left(1600 \mathrm{~N} / \mathrm{mm}^{2}\right)$ além de não apresentar deterioração em sua resistência flexional mesmo após dois anos de imersão em solução de Ringer. Comenta ainda o autor que a zircônia tem ainda como vantagem o fato de ser radiopaca a apresentar como melhor propriedade a habilidade de transmitir luz. Esta habilidade é fundamental para a estética das restaurações, pois a luz pode entrar no dente por duas direções; do periodonto para a coroa passando pela raiz ou da coroa para o periodonto passando também pela raiz.

Para comparar a transmissão de luz de um pino de zircônia e um de metal, dois núcleos foram fabricados para o mesmo dente em um paciente, o primeiro foi fabricado com zircônia e o segundo pela técnica de fundição com ouro. Uma coroa de cerâmica pura Empress foi confeccionada de maneira a se adaptar a ambos os núcleos. Primeiramente a coroa foi assentada sobre o núcleo metálico e uma luz branca foi incidida através do periodonto na raiz 
dental, os tecidos vizinhos ficaram iluminados com uma cor vermelha enquanto a coroa permaneceu escura. O núcleo metálico foi então substituído pelo de zircônia e o procedimento repetido, sendo evidente a diferença de iluminação com a coroa apresentando uma coloração amarelo-alaranjada semelhante ao dente natural vizinho.

No mesmo ano de 1998, MONDELLI ${ }^{42}$ descreveu o uso do pino de zircônia com a porção radicular restaurada em resina fotopolimerizável. Os pinos foram fixados com cimento resinoso, e a porção que entraria em contato com a resina composta foi silanizada para permitir a interação do material restaurador com o pino.

Segundo FREDRIKSSON; ASTBÄCK; PAMENIUS ${ }^{22}$ (1998) os materiais convencionais para restauração de um dentre tratado endodonticamente são: núcleo metálico fundido ou pino metálico pré-fabricado com reconstrução coronal em amálgama ou resina composta. No entanto estes autores enumeram algumas desvantagens que estão associadas a estes sistemas como pouca retenção dos pinos; potencial de fratura dos pinos e raízes e o risco de corrosão quando diferentes metais são usados para a restauração. Em seu trabalho, avaliaram os resultados de 236 dentes restaurados com pinos de fibra de carbono durante o período de 2 a 3 anos. Consideram os autores que os pinos pré-fabricados com reforço de fibras de carbono são confeccionados por fibras de carbono alinhadas, unidas a uma matriz especial de resina epóxica e apresentam resistência a fratura em torno de 1600 MPa e módulo de elasticidade de $21 \mathrm{GPa}$ semelhante à dentina o que distribui as forças de 
maneira mais uniforme ao longo da extensão do pino. Comentam ainda como vantagem deste sistema, a facilidade de remoção em caso de necessidade de retratamento do conduto radicular. Os autores verificaram, após a avaliação das unidades restauradas, que não foi encontrada nenhum deslocamento de pinos, coroas, nem fratura nas raízes.

Em 1999, STOCKTON; WILLIAMS ${ }^{57}$ avaliaram, in vitro, a retenção e a resistência à fratura de pinos de carbono e metálicos, colocados em dentes tratados endodonticamente. Trabalharam com 72 incisivos divididos em 6 grupos: Grupo 1- Pino Para Plus (Whaledent) cimentado com Ketac Cem (Espe); Grupos 2 e 3- Pino C-Post (Bisco), n. 1 e 2 respectivamente, cimentados com Bis-Core (Bisco). Nestes grupos foi avaliada a resistência à tração dos pinos. Para os grupos 4, 5 e 6 foi repetido o mesmo processo descrito anteriormente e a porção coronal dos dentes foi obtida com auxílio de uma matriz transparente preenchida com resina composta Bis-Core. Estes dentes foram ensaiados com carga a $135^{\circ}$ até a falha. A carga média para deslocar os pinos Para Plus (Tração) foi de 9,1 $\pm 2,4 \mathrm{~kg}$ enquanto para os pinos C-Post n. 1 e n. 2 foi de 10,6 $\pm 5 \mathrm{~kg}$ e 31,3 $\pm 9,4 \mathrm{~kg}$, respectivamente. A análise estatística não demonstrou diferença entre os grupos 1 e 2, porém o grupo 3 foi superior aos outros. Na avaliação de resistência à fratura, a carga necessária para causar falha nos pinos metálicos foi de $23,7 \pm 6,9 \mathrm{~kg}$ enquanto que nos pinos n.1 e n. 2 foi de 21,3 \pm 7,3 kg e 25,8 \pm 6,3 kg. A análise estatística não demonstrou diferença entre os grupos. Os autores concluíram que não havia 
vantagens no uso dos pinos de fibra sobre os pinos metálicos, do ponto de vista dos testes empregados.

MANNOCCI; FERRARI; WATSON ${ }^{38}$ em 1999 compararam o desempenho de dentes restaurados com pinos e recobertos com coroas de cerâmica pura quando submetidos ao teste de carga cíclica em meio úmido. Os pinos testados foram os de fibra de quartzo (Æsstheti Plus, RTD), fibra de carbono-quartzo (Æstheti Post, RTD) e dióxido de zircônia (Cerapost, Brasseler). Para tanto, os autores trabalharam com 40 pré-molares inferiores, uni-radiculares, com dimensões similares, os quais tiveram os canais tratados endodonticamente. Estes dentes foram envoltos em silicona de adição para simular o ligamento periodontal, montados em blocos de resina e divididos em três grupos de estudo e um grupo controle. Cada dente recebeu um preparo para pino com $8 \mathrm{~mm}$ de profundidade e os pinos foram cimentados sendo que, no grupo controle, nenhum pino foi cimentado. A porção coronária dos dentes foi reconstituída com resina composta e restaurada com a colocação de uma coroa de cerâmica pura Empress (Ivoclar). Os dentes foram testados em uma máquina de ensaio universal sendo colocados em um ângulo de 45 graus em relação ao longo eixo recebendo uma força de $250 \mathrm{~N}$ com a freqüência de duas cargas por segundo durante 400.000 ciclos. Nos grupos restaurados com pinos de fibra de quartzo e carbono-quartzo apenas um dente falhou por grupo enquanto no grupo restaurado com pinos de zircônia seis falhas aconteceram; uma coroa quebrou e cinco pinos e raízes fraturaram. Todos os dentes que não receberam pinos fraturaram. A análise estatística demonstrou que os pinos de 
dióxido de zircônia apresentaram um taxa de sucesso inferior aos pinos de fibras. Os autores concluíram que os pinos reforçados por fibra aumentaram a resistência de dentes restaurados com resina composta (núcleo de preenchimento) e coroas de cerâmica pura.

ASMUSSEN; PEUTZFELDT; HEITMANN ${ }^{4}$ (1999) trabalharam com diferentes tipos de pinos pré-fabricados para determinar a dureza, o limite de elasticidade e a resistência a fratura destes pinos. Quatro tipos de pinos foram analisados; dois pinos de zircônia (Biopost - Incermed e Cerapost - Brassler), um pino de titânio (PCR - Brassler) e um pino à base de fibras de carbono (Composipost - RTD). Estes pinos foram cimentados com Panavia 21 (Kuraray) em uma base metálica em que perfurações foram feitas de forma a deixar apenas $4,8 \mathrm{~mm}$ da porção coronária exposta. Após a presa do cimento por 24 horas a $37^{\circ} \mathrm{C}$, os pinos foram colocados a $45^{\circ}$ em relação à base e testados em uma máquina Instron de Ensaios Universais com uma velocidade de $0,05 \mathrm{~mm} / \mathrm{min}$ para produzir uma curva de força/deflexão. Dez amostras foram utilizadas para cada grupo. A análise estatística mostrou que não houve diferenças nas propriedades dos pinos de zircônia enquanto o pino de titânio (PCR) foi menos duro e teve um limite de elasticidade menor que os pinos de zircônia, mas apresentou a mesma resistência a fratura. O pino de fibra de carbono (Composipost) obteve valores em todas as propriedades menores que os outros tipos de pinos. O valor do limite de elasticidade foi idêntico à resistência a fratura para os pinos de zircônia o que indica que estes pinos são friáveis e não apresentam ductibilidade. De maneira oposta, os pinos de titânio 
e fibras de carbono tiveram limites de elasticidade menores que a resistência à fratura, indicando um comportamento plástico.

Em 1999, SIRIMAI; RIIS; MORGANO ${ }^{54}$ pesquisaram a resistência à fratura de dentes restaurados com núcleos metálicos fundidos fixados com cimento de fosfato de zinco e pinos pré-fabricados fixados com cimento resinoso Variolink. Verificaram que os com núcleos metálicos fundidos cimentados com cimento de fosfato de zinco apresentavam uma maior resistência à falha por fratura do que os pinos fixados com cimentos resinosos porém, quando esta ocorria, na maioria das vezes, era no sentido vertical da raiz. Concluíram os autores que, os pinos pré-fabricados fixados com cimento resinoso falharam com uma carga menor, porém, reduziram significantemente as fraturas verticais nas raízes.

Também em 1999, $\mathrm{CHO}$ et $\mathrm{al}^{6}$ avaliaram a resistência à compressão e tração diametral de nove materiais restauradores (1- Ketac Fill - ionômero de vidro, ESPE; 2- Ketac Silver - ionômero de vidro modificado, ESPE; 3- Vitremer - ionômero de vidro reforçado por resina, 3M; 4- Structure - poliuretano, Cadco; 5- Ti Core - resina autopolimerizável reforçada por titânio, EDS; 6- Core Paste resina autopolimerizável reforçada por titânio, Den-Mat; 7- Herculite - resina composta fotopolimerizável, Kerr; 8- Prodigy - resina composta fotopolimerizável, Kerr; 9- Valiant - amálgama de cobre, Ivoclar). Para o ensaio de compressão prepararam em uma matriz 10 corpos de prova de cada tipo de material com as dimensões de $6 \mathrm{~mm} \times 4 \mathrm{~mm}$ e para o ensaio de tração diametral, mais 10 corpos por material com as dimensões de $6 \mathrm{~mm} \times 2 \mathrm{~mm}$. No 
ensaio de compressão, os corpos foram colocados com sua maior dimensão no sentido horizontal na máquina de testes e para o ensaio de tração diametral, com a maior dimensão no sentido vertical. Os valores individuais foram calculados usando a carga na qual houve falha e as dimensões da amostra testada.

Os autores verificaram que os valores para o ensaio de compressão variaram de 61,1 MPa (Structure) a 250,3 MPa (Prodigy). Para o ensaio de tração diametral os valores variaram de 18,3 MPa (Ketac Silver) a 55,1 MPa (Prodigy). Em ambos os teste não houve diferença estatística entre os grupos preparados com as resinas fotopolimerizáveis e o amálgama. O material mais resistente à compressão suportou uma carga 4 vezes maior que o material menos resistente e 3 vezes a carga quando avaliado quanto a tração diametral.

Segundo os autores, as resinas compostas apresentam como vantagens o fato de serem translucentes, apresentarem cor semelhante ao dente não causando o escurecimento, união ao dente através de adesivos e, por apresentarem uma presa rápida, permitem o preparo imediato do dente. Como desvantagens podem não apresentar completa polimerização se não houver suficiente intensidade de luz ou tempo de polimerização e sofrem alterações dimensionais por absorção de água. Concluíram que as resinas compostas apresentaram propriedades semelhantes ao amálgama e que as resinas fotopolimerizáveis são mais resistentes que as resinas autopolimerizáveis.

MANNOCCl et $a^{39}{ }^{39}$ também em 1999 avaliaram a zona de interdifusão dentina/resina; a presença de bolhas na interface pino/resina/dentina e a 
estrutura interna de diversos pinos de fibra com auxílio de microscópio óptico e microscópio eletrônico de varredura. Utilizaram 42 pré-molares inferiores divididos em 7 grupos de 6 dentes cada. Para o grupo 1, os dentes foram restaurados com pinos de carbono (RTD) cimentados com All Bond 2 e cimento resinoso C\&B (Bisco). No grupo 2, foram utilizados os pinos de carbono (Spad) e All Bond 2/ C\&B. Grupo 3, pinos experimentais de quartzo (RTD) cimentados com All Bond 2/ C\&B. Para o grupo 4, utilizaram pinos de carbono recobertos com quartzo (RTD) cimentados com All Bond 2/ C\&B. No grupo 5 trabalharam com pinos de titânio ParaPost (Whaledent) cimentados com All Bond 2/ C\&B. O grupo 6 foi constituído de dentes restaurados com pinos de carbono (RTD) cimentados com Panavia 21 (Kuraray). Para o grupo 7 utilizaram pinos de carbono (Tech 2000) cimentados com Panavia 21 (Kuraray).

Todos os canais foram preparados química e mecanicamente e restaurados com guta-percha e cimento endodôntico AH26 (De Trey Konstanz). Os espaços para os pinos foram preparados com uma profundidade de $9 \mathrm{~mm}$ com as brocas fornecidas pelos fabricantes, o processo de cimentação foi conduzido de acordo com as orientações dos fabricantes dos cimentos resinosos e a porção coronária, de todos os dentes, foi confeccionada com resina composta Bis Core (Bisco). Após a imersão dos grupos em solução salina pelo período de três semanas, os dentes foram seccionados paralelamente ao longo eixo usando disco diamantado (Isomet) em baixa velocidade, sob refrigeração à água. Para padronizar o local de leitura, 3 endentações foram feitas com lâmina de bisturi a uma distância de 2, 5 e 8 mm 
da junção dentina/resina restauradora da porção coronal. As observações foram feitas em uma metade do dente com o microscópio confocal e na outra metade com o microscópio eletrônico de verredura, na interface pino/resina/dentina nas áreas apical e coronal das endentações.

Os autores observaram que a proporção entre o comprimento da zona de interdifusão resina/dentina e o comprimento da interface observada foi estatisticamente significante maior nos grupos tratados com agente de união do que nos grupos trabalhados com o Panavia 21. Os prolongamentos de resina das raízes tratadas com All Bond 2 eram muito maiores do que os das raízes tratadas com o Panavia 21. Observaram também que não houve diferença estatística entre os grupos tratados com o mesmo adesivo e que não houve diferença nas dimensões das fibras entre os vários tipos de pinos, todos estavam entre 8 a $9 \mu \mathrm{m}$.

Os autores concluíram que o uso de um sistema adesivo de três passos deve ser utilizado para se obter uma boa união entre o cimento resinoso, resina composta e paredes do conduto radicular.

HOCHMAN; ZALKIND ${ }^{26}$ (1999) descreveram técnica de obtenção de pino fundido em cerâmica de Zircônia. Alegaram que os núcleos metálicos fundidos têm propriedades físicas inferiores e que podem produzir uma sombra cinza quando utilizados em conjunto com coroas de cerâmica pura. Utilizaram brocas do sistema Cosmo Post (Ivoclar) para preparar o conduto e adaptaram um pino pré-fabricado em Zircônia de tamanho semelhante à última broca. Removeram esse pino com uma moldagem da arcada e enceraram a porção 
coronária. O conjunto foi incluído em revestimento próprio para fundição de cerâmica (IPS Empress - Ivoclar) e levado ao forno de fundição no qual a cerâmica fundida foi prensada. Relataram os autores que esta técnica está contra-indicada em dentes com canais elípticos e amplos.

COHEN et $\mathrm{al}^{8}$, em 2000, analisaram a resistência à fadiga cíclica de cinco tipos diferentes de pinos pré-fabricados: 1- AccessPost; 2- Flexi-Flange; 3- Flexi-Post; 4- ParaPost e 5- Vlock associados a quatro diferentes materiais de restauração coronária: 1- Amálgama Tytin; 2- Ti-Core; 3- Ketac-Silver e 4GC Miracle Mix. Utilizaram para este teste 100 dentes recém-extraídos divididos em 20 grupos de cinco unidades combinando os diferentes tipos de pinos com os diferentes materiais restauradores. Após o ensaio de fadiga em uma máquina com uma carga de 5 libras aplicada sobre os dentes com uma freqüência de 3 ciclos por segundo durante 4.000 .000 de ciclos, verificaram que apenas os dentes restaurados com amálgama e com a resina Ti-Core completaram o teste sem falhas. Todos os dentes restaurados com os dois tipos de ionômero de vidro apresentaram falha na porção coronária antes de se completarem os ciclos. Verificaram também que apesar das falhas na porção coronal, todos os pinos pré-fabricados preservaram sua cimentação com o dente.

Em sua discussão os autores justificaram este estudo comentando que a habilidade do sistema restaurador pino/preenchimento coronário sobreviver aos esforços mastigatórios é um fator crítico para a sobrevivência da restauração definitiva, ressaltando que a força média a que um dente anterior está 
submetido é de 60 libras e um dente posterior, 145 libras. Lembraram também que as resinas compostas apresentam várias vantagens na reconstrução coronária incluindo alta resistência, fácil manipulação, menor tempo de presa, propriedades mecânicas como resistência à compressão (41.131 psi) e resistência à tração diametral (5.219 psi) semelhantes à da dentina (43.100 psi e 6.000 psi respectivamente) propiciando ao dentista o completo preparo coronário imediatamente após a cimentação do pino pré-fabricado.

FERRARI; VICHI; GARCIA-GODOY ${ }^{19}$ em 2000 avaliaram o resultado do tratamento de dentes restaurados com núcleos metálicos e pinos reforçados por fibra, recobertos com coroas metalocerâmicas, após 4 anos de instalação das próteses. Usaram 200 dentes tratados endodonticamente com severa perda estrutural, divididos aleatoriamente em dois grupos experimentais. Para o grupo 1, utilizaram o pino Composipost (RTD, Grenoble, France) com uma profundidade de $9 \mathrm{~mm}$, cimentados com cimento resinoso C\&B (Bisco Co, Schaumburg, IL, USA) e restaurados com Bis-Core (Bisco Co, Schaumburg, IL, USA). Para o grupo 2, trabalharam com núcleos metálicos fundidos obtidos por técnica indireta, cimentados com cimento de fosfato de zinco. Todos os dentes foram restaurados com coroa metalocerâmica e radiografias periapicais foram realizadas após a cimentação e após 6 meses, 1, 2 e 4 anos. A taxa de sucesso do tratamento foi baseada nas avaliações clínicas e radiográficas conduzidas por um mesmo examinador. Os resultados encontrados para 0 grupo 1 foram de $95 \%$ de sucesso clínico, $2 \%$ de falhas devido a problemas endodônticos e $3 \%$ dos dentes excluídos da avaliação pelo não 
comparecimento dos pacientes. Para o grupo 2, 84\% dos dentes apresentaram sucesso clínico, 9\% fratura das raízes, $2 \%$ deslocamento das coroas, 3\% falhas endodônticas e $2 \%$ não compareceram à avaliação. Com base nos resultados da análise estatística, os autores concluíram que o sistema de pino reforçado por fibras apresentou um resultado superior ao núcleo convencional.

COHEN et $\mathrm{al}^{9}$, também em 2000, compararam a retenção de dois tipos de material restaurador suportados por três tipos de pinos pré-fabricados. Os autores testaram seis grupos com dez amostras cada, divididos entre pinos pré-fabricados do tipo Flexi-Post e Access-Post (Essential Dental Systems) feitos em aço inoxidável e um pino pré-fabricado em material cerâmico (CeraPost - Brassler - USA), restaurados com resina composta reforçada por titânio (Ti-Core -Essential Dental Systems) e ionômero de vidro (GC Miracle Mix - GC Corporation).

A porção coronária dos pinos foi confeccionada em uma matriz com as dimensões de $5 \mathrm{~mm} \times 8 \mathrm{~mm}$. Cada corpo de prova foi preparado seguindo as recomendações dos fabricantes e o material restaurador foi colocado na matriz com auxílio de uma seringa Centrix (Centrix Corp, Shelton, Conn.) e removido após uma hora. Os corpos de prova foram estocados a $100 \%$ de umidade por vinte e quatro horas antes de se iniciar os ensaios.

Os corpos de prova foram instalados em uma máquina de ensaios e, com auxílio de um dispositivo especial, foram submetidos ao ensaio de tração para avaliar a retenção do material restaurador ao pino. Os resultados encontrados demonstraram que a retenção dos materiais restauradores foi 
maior para os pinos metálicos do que para os pinos cerâmicos. Os autores sugeriram que este fato deve-se, provavelmente, à falta de mecanismos de retenção macro-mecânica nos pinos Cera-Post, cuja superfície é lisa.

Comparando os materiais restauradores, verificaram que o material resinoso reforçado por titânio (Ti-Core) apresentou um melhor desempenho no ensaio de tração do que o material ionomérico (GC Miracle Mix) em todos os tipos de pinos testados. O resultado da comparação Ti-Core - GC Miracle Mix foi: 151,1 N para o Access-Post; 32,4 N para o Cerapost e 176,6 N para o Flexi-Post.

Os autores concluíram que o desenho dos pinos metálicos favoreceu a uma melhor retenção dos materiais restauradores e que o material resinoso reforçado por titânio apresentou maior retenção aos pinos do que o material ionomérico.

ROSENTRITT et $\mathrm{al}^{50}$ (2000) avaliaram a resistência à fratura de pinos de cerâmica, metal e reforçados por fibras após simulação de 5 anos na cavidade oral. Um total de 56 incisivos centrais foi usado sendo que, 42 foram divididos em 6 grupos e 14 em 2 grupos para serem usados na segunda parte do trabalho. Para simular o ligamento periodontal, as raízes foram recobertas com uma camada de aproximadamente $1 \mathrm{~mm}$ de espessura de poliéter e embebidas em resina acrílica até uma altura de $3 \mathrm{~mm}$ de distância da linha amelo-cementária. A porção coronária foi removida com disco diamantado e os canais foram tratados endodonticamente. Os grupos consistiam em dentes restaurados com: 1- CosmoPost com porção coronária em cerâmica Cosmo; 2- 
Titânio e porção coronária em resina composta Tetric Ceram; 3- Ouro e porção coronária em ouro; 4- IPS Empress e porção coronária em cerâmica IPS Empress; 5- Pinos de fibra experimentais feitos pelos autores a partir do Vectris (Ivoclarvivadent) e a porção coronária em resina composta Tetric Ceram; 6CosmoPost e a porção coronária em resina composta Tetric Ceram. A porção coronária de todos os grupos foi obtida com uma matriz transparente. Os corpos de prova foram submetidos a ciclagem térmica $\left(6.000\right.$ ciclos de $5^{\circ} \mathrm{C} /$ $\left.50^{\circ} \mathrm{C}\right)$, ciclagem mecânica $\left(1,2 \times 10^{6}\right.$ ciclos a $135^{\circ}$ e $\left.50 \mathrm{~N}\right)$ e levados a uma máquina de ensaios para a aplicação de carga (velocidade de $1 \mathrm{~mm} / \mathrm{min}$ ) até que falhassem.

$\mathrm{Na}$ segunda parte do trabalho, restauraram 7 incisivos com pinos cerâmicos CosmoPost combinados com Tetric Ceram e coroas cerâmicas IPS Empress. No segundo grupo, restauraram os dentes com os pinos experimentais Vectris combinados com Tetric Ceram e coroas em Targis/Vectris. Os dentes foram submetidos a ciclagem térmica e mecânica e levados à máquina de ensaios e foram testados com uma carga incidindo em $135^{\circ}$

Os autores verificaram que o conjunto pino/porção coronal em cerâmica suportou uma menor carga do que os pinos de ouro. Os pinos de titânio e de cerâmica restaurados com Tetric Ceram apresentaram valores significantemente maiores do que os pinos de ouro e apenas os pinos de vectris tiveram valores sem diferença estatística em relação aos pinos de ouro. 
Em relação à segunda parte do trabalho, no grupo de dentes restaurados com coroas cerâmicas, 4 dos 7 corpos de prova falharam durante o ensaio e 2 dos 7 espécimes do grupo restaurado com Targis/Vectris também, porém, os valores foram semelhantes do ponto de vista estatístico.

Os autores concluíram que os sistemas totalmente cerâmicos apresentaram boa resistência à fratura em relação aos pinos de ouro e os sistemas pino/resina composta apresentaram valores ainda melhores.

COHEN et $\mathrm{al}^{10}$ (2000) avaliaram a resistência torcional de coroas cimentadas a pinos metálicos pré-fabricados com preenchimento coronário em resina composta. Usaram 30 incisivos recém-extraídos com a porção coronária seccionada na junção amelo-cementária, divididos em três grupos: restaurados com pino AccessPost (Essential Dental Systems); Flexi-Post (Essential Dental Systems) e ParaPost (Coltene/Whaledent). Os condutos foram preparados para receber os pinos numa profundidade de $10 \mathrm{~mm}$, seguindo as instruções dos fabricantes. A porção coronária foi preenchida com a resina Ti-Core (Essential Dental Systems), preparada com broca diamantada deixando um ombro biselado e moldada com silicona de adição para obtenção dos troqueis onde foram confeccionadas as coroas que foram finalmente cimentadas aos respectivos dentes com cimento de fosfato de zinco Flecks (Mizzy Inc). Os espécimes foram deixados em água por uma semana antes do ensaio de torção.

As amostras foram instaladas em uma base especial na máquina de ensaios e sofreram uma força torcional no sentido horário até que a coroa com 
o pino fosse removida da raiz. Nenhum pino fraturou durante o ensaio e a análise estatística revelou que os dentes restaurados com o pino Flexi-Post apresentaram uma maior resistência à remoção por torção $(162,2$ polegada $x$ onça) do que os outros grupos (AccessPost- 77,16 e ParaPost- 60,9). Os autores atribuíram estes resultados ao desenho do pino que apresenta um corte no sentido longitudinal em sua porção radicular o que resulta em uma maior resistência à torção. Afirmaram também que é razoável se presumir que uma combinação do pino com o material restaurador coronário que ofereça uma maior resistência, favorece a uma maior sobrevivência da restauração no uso in vivo.

BROWN ${ }^{5}$ em 2000 relatou que o mundo dos materiais é dividido em três classes básicas: cerâmicas, metais e polímeros e a mistura de dois ou mais classes gera o compósito. Lembrou que por mais de 30 anos os compósitos são utilizados na Odontologia e que a combinação de polímeros e cerâmicas tem levado a melhoria das propriedades dos materiais restauradores. Relatou o autor que, atualmente, fibras provenientes destas três classes de materiais estão sendo incorporadas no uso Odontológico melhorando ainda mais as propriedades dos materiais. Estas fibras têm diâmetros variando de 3 a 300 micrometros e, para que o reforço seja efetivo, precisam ter união química com o material da matriz. O método que tem sido empregado para propiciar a adesão de fibras cerâmicas à resina (polímero) consiste em cobrir a fibra com partículas de sílica fundida a alta temperatura e então silanizar a superfície para que apresente união química com a matriz. Relatou também que as fibras 
de carbono ou quartzo tem sido empregadas na confecção de pinos intraradiculares, produzindo pinos com dureza semelhante à dentina.

DRUMMOND ${ }^{17}$ em 2000 comparou a resistência à remoção por tração de pinos pré-fabricados em aço inoxidável e três diferentes pinos reforçados por fibra cimentados em raízes de terceiros molares. Para tanto o autor utilizou pinos de carbono, de aço inoxidável, e os pinos reforçados por fibras ÆEsthethic, Light e FiberKore, em um número de 20 pinos por grupo, tratados com All-Bond e cimentados com C\&B Cement (Bisco) em 100 terceiros molares com a porção oclusal removida e com os condutos preparados de acordo com os fabricantes dos pinos. As amostras foram testadas em uma máquina de ensaios Instron com uma velocidade de $2 \mathrm{~mm} / \mathrm{min}$. A maior média de força necessária à remoção dos pinos foi de $6,6 \pm 2,9 \mathrm{MPa}$ para os pinos de aço inoxidável e a menor média foi de 3,8 \pm 1,9 MPa para os pinos Light. A análise estatística, porém, demonstrou que não houve diferença entre os grupos. 0 autor também avaliou a influência da ciclagem térmica na resistência flexional dos pinos reforçados por fibra. A análise estatística revelou que houve diferença significante entre todos os grupos testados demonstrando que os pinos sofreram fadiga durante a ciclagem térmica. Os pinos de Carbono foram os que apresentaram melhores resultados (1.492 $\pm 19 \mathrm{MPa}$ antes da ciclagem térmica e $1.332 \pm 50 \mathrm{MPa}$ após) enquanto que os pinos reforçados por fibra de vidro apresentaram um maior decréscimo na resistência (entre 11\% e 21\%).

XIBLE $^{60}$ (2000) comparou três técnicas de confecção de pino quanto à resistência ao cisalhamento na interface pino material restaurador. $\mathrm{O}$ autor 
trabalhou com três grupos de pinos: 1- Pino cerâmico de zircônia CosmoPost (Ivoclar) com a porção coronária reconstruída por cerâmica fundida Empress (Ivoclar); 2- Pino cerâmico de zircônia CosmoPost (Ivoclar) com a porção coronária reconstruída por resina composta Tetric Ceram (Ivoclar) e 3- Pino de titânio Tenax (Whaledent) com a porção coronária reconstruída por resina composta Tetric Ceram (Ivoclar). Verificou o autor após os ensaios de cisalhamento que os pinos de zircônia fundidos com Empress e os pinos de titânio restaurados com resina composta não apresentaram diferenças estatisticamente significantes entre si, porém, foram melhores quando comparados com o grupo de pinos de zircônia restaurados com resina composta.

STRUB; PONTIUS; KOUTAYAS ${ }^{58}$ (2001) avaliaram a taxa de sobrevida e a resistência à fratura de incisivos, tratados endodonticamente, restaurados com quatro diferentes sistemas de pinos e núcleos associados a coroas de cerâmica pura, após exposição em boca artificial. Usaram 40 incisivos divididos em 4 grupos: 1- Núcleos metálicos em ouro cimentados com fosfato de zinco (Mizzy); 2- Pinos de zircônia Cerapost (cimentados com Panavia TC (Kuraray) e porção coronária de cerâmica pré-fabricada Ceracap cimentada aos pinos; 3Pinos de cerâmica infiltrada com resina (experimental) e porção coronária de cerâmica pré-fabricada Ceracap cimentada aos pinos; 4- Pinos Cerapost com porção coronária em porcelana fundida Cosmo. Todos os espécimes foram moldados, as coroas foram obtidas através do sistema CAD-CAM Procera e cimentadas com Panavia TC. Todos os corpos foram submetidos à simulação 
de 5 anos em uma boca artificial para cálculo da taxa de sobrevida. Após 1.200 .000 ciclos a taxa foi de $90 \%, 80 \%, 60 \%$ e $100 \%$ para os grupos $1,2,3$, e 4 respectivamente. A análise estatística mostrou diferenças entre todos os grupos com exceção dos grupos 1 e 2 e dos grupos 1 e 3 . O ensaio de compressão foi realizado após o ensaio de fatiga até a falha dos espécimes. Os pinos de zircônia (grupo 4) apresentou o mais baixo valor médio (463,3 N) em comparação aos outros 3 grupos (1- 1.270 N; 2- 1.494,5 N e 3- 11.467,7 N). Os autores concluíram que apesar do valor dos pinos Cerapost ter sido baixo, ainda assim, foi 1 vez e meia maior que o valor clínico necessário para a área anterior (290 N), podendo serem utilizados para os dentes anteriores.

Em 2001, HEW; PURTON; LOVE ${ }^{25}$ avaliaram as propriedades de 2 tipos de pinos metálicos, um de titânio (IntegraPost - Premier) e um de aço inoxidável (ParaPost- Coltène/Whaledent). Testaram a rigidez dos pinos usando o ensaio de três pontos, a retenção ao material restaurador e a retenção à raiz com ensaios de tração. Comentaram os autores que os pinos do sistema ParaPost normalmente são escolhidos para grupo controle devido aos dados na literatura indicando sucesso clínico e porque em vários países ele é usado como padrão para a indústria de pinos paralelos pré-fabricados. Nos testes de rigidez verificaram que os pinos de titânio apresentaram valores inferiores aos pinos de aço inox, $0,04 \mathrm{~N} / \mu \mathrm{m}$ versus $0,18 \mathrm{~N} / \mu \mathrm{m}$, sendo confirmada a diferença estatística entre estes pinos. Nos ensaios de retenção da resina composta usada para restaurar a porção coronária (CompoCore Premier) aos pinos metálicos, os dois tipos apresentaram valores similares 
quando comparados estatisticamente porém, numericamente o pino de titânio apresentou valores mais elevados (IntegraPost $=490 \pm 139 \mathrm{~N}$; ParaPost $=380$ $\pm 146 \mathrm{~N})$. Os ensaios de tração dos pinos cimentados com Panavia 21 (Kuraray) revelaram que ambos apresentaram o mesmo desempenho do ponto de vista estatístico (IntegraPost $=227 \pm 32 \mathrm{~N}$; ParaPost $=236 \pm 48 \mathrm{~N}$ ). Os autores concluíram que o pino de titânio é menos rígido que o pino de aço inox e que devem ser evitados em áreas que grandes cargas mastigatórias sejam previstas tais como: overbite profundo, bruxismo ou história prévia de falha dos pinos.

CORMIER; BURNS; MOON ${ }^{11}$ (2001) avaliaram a resistência e o modo de fratura de pinos reforçados com fibra, cerâmicos e convencionais. Usaram 6 tipos de pinos e 4 estágios de simulação clínica, com 10 amostras por grupo, para determinar a resistência à fratura em cada estágio do tratamento, o tipo de falha de cada sistema de pino e a facilidade de remoção dos pinos cimentados. Os tipos de pinos foram: 1- AesthetiPost (Bisco); 2- C-Post (Bisco); 3- FibreKor Post (Jeneric/Pentron); 4- CosmoPost (Ivoclar Vivadent); 5- ParaPost fundido (Coltène/Whaledent) e 6- ParaPost (Coltène/Whaledent). Os estágios de simulação clínica foram: 1- Teste do pino (ensaio de três pontos); 2- pinos cimentados nas raízes; 3- pinos cimentados e reconstrução coronária e 4pinos cimentados, reconstrução coronária e coroa metálica cimentada.

Os teste da $1^{\underline{a}}$ fase foram realizados com uma secção de $10 \mathrm{~mm}$ de comprimento de cada tipo de pino. Os ensaios foram conduzidos em uma máquina de ensaios universal Instron, com uma velocidade 0,05 polegadas por 
minuto e com a força localizada no centro dos pinos apoiados à distância de 2 $\mathrm{mm}$ de suas extremidades. Nas fases 2,3 e 4 os pinos foram cimentados nas raízes que estavam presas em blocos de resina acrílica com uma porção coronária exposta de $3 \mathrm{~mm}$, usando o material recomendado por cada fabricante, com o objetivo de se usar o potencial máximo de cada sistema e nas fases 3 e 4 a porção coronária foi restaurada, também seguindo o procedimento indicado para cada produto. A força foi aplicada sempre a uma distância de $4 \mathrm{~mm}$ da junção amelo-cementária com uma angulação de $90^{\circ} \mathrm{o}$ que, segundo os autores, simula uma situação traumática que um dente anterior pode sofrer em caso acidental e a pior situação em que uma força é aplicada a uma restauração.

Os resultados mostraram que para a situação número 1 (resistência flexional) o pino ParaPost apresentou a maior média em Newton $(1.089,3)$ e o pinos AesthetiPost, FibreKor Post e C-Post os menores valores porém iguais entre si $(212,1 ; 206,1$ e 184,8 respectivamente). De uma maneira geral o pino ParaPost teve um desempenho estatisticamente superior aos outros pinos e os pinos reforçados por fibras um resultado semelhante entre si. Em relação ao tipo de fratura, os pinos metálicos e o cerâmico apresentaram um alto número de fraturas não tratáveis (fratura vertical ou oblíqua estendendo-se abaixo do bloco de acrílico) enquanto os pinos reforçados por fibras apresentaram um número significantemente menor deste tipo de fraturas. Estes pinos também foram removidos em um tempo médio de 1:20 minutos enquanto que os 
metálicos e cerâmico não foram removidos em um período de 30 minutos ou o desgaste de 5 brocas diamantadas, o que ocorresse primeiro.

Os autores concluíram que o C-Post e o Aestheti-Post constituem um avanço em relação aos núcleos convencionais que são conhecidos pela descoloração dos tecidos e das raízes e por apresentarem, como demonstrado neste trabalho, um alto número de fraturas dentais não tratáveis. Concluíram ainda que o FibreKor Post foi o material mais fraco de todos os testados e que os pinos reforçados por fibra são facilmente removidos após falha enquanto o restante dos pinos não puderam ser removidos.

Também em 2001, MARTíNEZ-GONZÁLES et al ${ }^{41}$ estudaram a influência da carga de compressão contínua sobre três tipos de pinos fundidos (níquel-cromo, resina acetálica e porcelana IPS-Empress [Ivoclar]) e seus efeitos sobre coroas e dentes. Usaram 30 caninos recém-extraídos que foram seccionados a $1,5 \mathrm{~mm}$ abaixo da região amelo-cementária e tratados endodonticamente. A porção radicular foi preparada com brocas do sistema ParaPost (Coltène/Whaledent) com um diâmetro de 1,2 mm e com $10 \mathrm{~mm}$ de profundidade. Os dentes foram divididos em três grupos, de acordo com o tipo de pino. Os pinos foram obtidos por técnica indireta seguindo as recomendações dos fabricantes. Após a cimentação dos pinos, os dentes foram presos em cilindros de cobre com resina acrílica, preparados deixando uma ferulização de 1,5 mm e moldados para a obtenção das coroas.

Após a cimentação das coroas com fosfato de zinco, os corpos de prova foram testados recebendo uma força aplicada na porção palatina com 
inclinação de $45^{\circ}$, a uma velocidade de $0,5 \mathrm{~mm} / \mathrm{min}$. Os testes eram interrompidos no momento da falha da restauração ou fratura do dente. Após os ensaios, os cilindros de cobre eram removidos e a porção coronária de cada espécime foi envolvida com resina transparente. Cada espécime foi seccionado em duas partes na direção vestíbulo-lingual, polido e avaliado em lupa estereoscópica (Nikon) para se avaliar o padrão de fratura e anormalidades. As médias de valores do ensaio de compressão foram: $2.120 \pm 655 \mathrm{~N} ; 1.490 \pm 662$ $\mathrm{N}$ e $2.139 \pm 563 \mathrm{~N}$ para os pinos de níquel-cromo, IPS-Empress e resina acetálica, respectivamente. A comparação estatística demonstrou que não houve diferença estatística entre os pinos de níquel-cromo e os de resina acetálica. A análise em lupa demonstrou que a maior incidência de fraturas dentais na região apical ocorreu no grupo dos pinos de níquel-cromo (70\%) enquanto que foram detectadas este tipo de fratura em $30 \%$ dos pinos cerâmicos e em $40 \%$ dos pinos de resina. A análise estatística, no entanto, não revelou diferença entre os grupos quanto ao tipo de fratura. Os autores concluíram que os pinos de níquel-cromo e de resina acetálica possuem a mesma resistência à carga continuada e que os pinos metálicos apresentam uma maior tendência de fraturar ao nível apical do que os outros tipos de pinos.

Também 2002, HSU et $\mathrm{al}^{28}$ avaliaram a resistência à fatiga de pinos metálicos pré-fabricados com porção coronária restaurada com resina composta com e sem uso de adesivos dentinários. Os autores usaram 10 incisivos centrais superiores recém-extraídos com comprimento mínimo de raiz de $11 \mathrm{~mm}$ após secção coronária $1 \mathrm{~mm}$ abaixo da junção amelo-cementária. 
Os condutos radiculares foram preparados com brocas do sistema Parapost (Coltène/Whaledent) com diâmetro final de $1,25 \mathrm{~mm}$ e os dentes foram montados em cilindros metálicos com resina acrílica auto-polimerizável. O preparo inicial dos dentes para coroa total foi feito com brocas KS-1 (Brasseler) deixando um ombro de $1 \mathrm{~mm}$ de profundidade. Os autores usaram pinos préfabricados ParaPost (Coltène/Whaledent), o agente de união Scotchbond MultiUso Plus (3M), o cimento resinoso Rely-X (3M) e a resina composta Corestore (Kerr) Os dentes foram divididos em 2 grupos. No grupo 1, o canal foi tratado com ácido fosfórico seguida da aplicação do ativador e do primer do sistema Scotchbond Multi-Uso Plus, uma gota do adesivo e do catalizador foram misturadas e aplicada sobre a dentina. O cimento resinoso foi manipulado, aplicado ao pino e este levado ao canal e mantido em posição durante a fotopolimerização por 40 segundos. A porção coronal foi restaurada com a resina Corestore. Para o grupo 2, os autores evitaram o contato do ácido e do sistema adesivo com a dentina superficial e confeccionaram a porção coronal com a resina Corestore. Os dentes foram moldados, as coroas definitivas foram cimentadas com cimento fosfato de zinco e levados à máquina de ensaios. No grupo 1 (com adesivo dentinário) apenas 1 coroa falhou antes de 100.000 ciclos e no grupo 2 todas as coroas falharam antes de se completarem os 100 primeiros ciclos. Os autores concluíram que o uso de adesivos dentinários na reconstrução coronal proporciona uma maior retenção das coroas definitivas quando submetidas à fatiga. 
OTTL et $\mathrm{al}^{45}$, também em 2002, compararam a característica das fraturas de oito tipos de pinos de fibra, cerâmicos e metálicos submetidos à carga, cimentados em raízes artificiais. Trabalharam com 8 grupos de 10 espécimes com pinos de liga de paládio (Perma-dor Post, Degussa), liga de não-paládio (Perma-dor Twin, Degussa), liga de paládio/irídio (ER Post,Komet), liga de prata/irídio (Endo-Core,Metalor), pinos de zircônia (ER Cerapost, Komet), pinos de óxido de alumíno (Celay, Vita) e pinos de fibra de carbono (C-Post, Bisco). Para os pinos metálicos a porção coronária foi confeccionada com uma matriz em acrílico e posteriormente fundida com liga metálica. Para os pinos de zircônia e de fibras de carbono a porção coronária foi feita com a mesma matriz preenchida com resina composta Clearfil Core (Kuraray). Os pinos de óxido de alumínio foram confeccionados na máquina do sistema Celay a partir de uma réplica do pino Perma-dor com a porção formada na matriz com a resina CelayTech (Mikrona).

O dente utilizado como referência foi um incisivo central superior moldado em uma matriz transparente de resina Palapress (Haerus Kulzer). Esta matriz foi preenchida com resina composta para dentes posterior Estilux (Haerus Kulzer) cujo módulo de elasticidade (16,4 \pm 1 GPa) se assemelha ao da dentina (14 a $18 \mathrm{GPa}$ ). Para confecção dos condutos radiculares os pinos, devidamente lubrificados com vaselina, foram imersos centralizados na resina com auxílio de um paralelômetro e a resina fotopolimerizada (Aparelho Dentacolor XS, Haerus Kulzer). Após a polimerização, os pinos foram removidos e os condutos preparados com as brocas dos respectivos sistemas 
a uma profundidade de $9 \mathrm{~mm}$ e uma abertura vestíbulo-lingual de $3 \mathrm{~mm}$ e mésio-distal de $2 \mathrm{~mm}$ com uma profundidade de $2 \mathrm{~mm}$ na câmara pulpar com área de ferulização de 1,5 mm. Após a cimentação dos pinos com Panavia 21 (Kuraray), as coroas definitivas foram obtidas com auxílio de uma matriz que reproduzia a porção coronal do incisivo central e as coroas fundidas foram cimentadas nas raízes com o mesmo material com uma pressão de $5 \mathrm{~kg}$ por 10 minutos. Todos os corpos de prova foram estocados a $100 \%$ de umidade durante $24 \mathrm{~h}$ antes dos ensaios.

Os testes foram conduzidos em uma máquina de ensaios universais com uma pressão aplicada em um ângulo de $135^{\circ}$ em relação ao longo eixo do dente a uma velocidade de $0,5 \mathrm{~mm} / \mathrm{min}$. Os espécimes foram colados em um dispositivo metálico usando um material elastomérico (Permadine Garant, Espe) para simular o periodonto. Os resultados revelaram que os pinos de fibra de carbono apresentaram o mais alto valor de resistência a fratura $(312,5 \pm$ 58,8 N) apresentando diferença estatística em relação aos outros grupos. 
W.

\&6 2

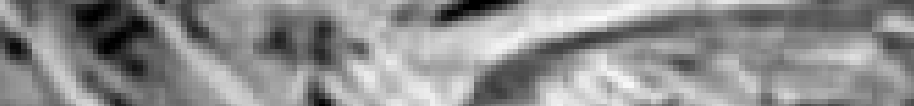

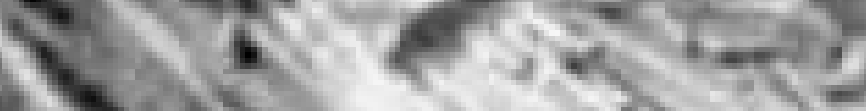

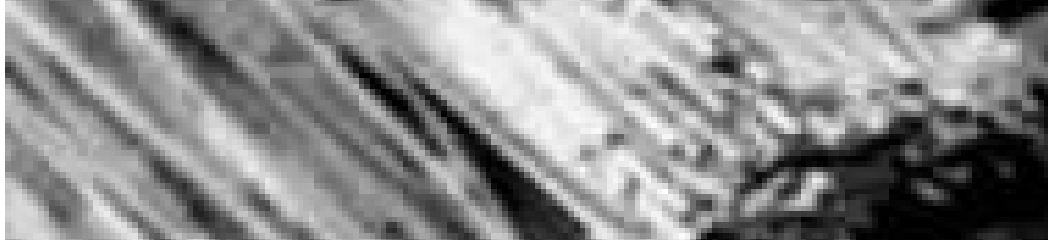

WhW Whaters

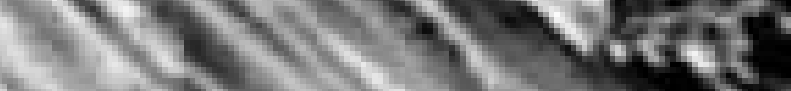

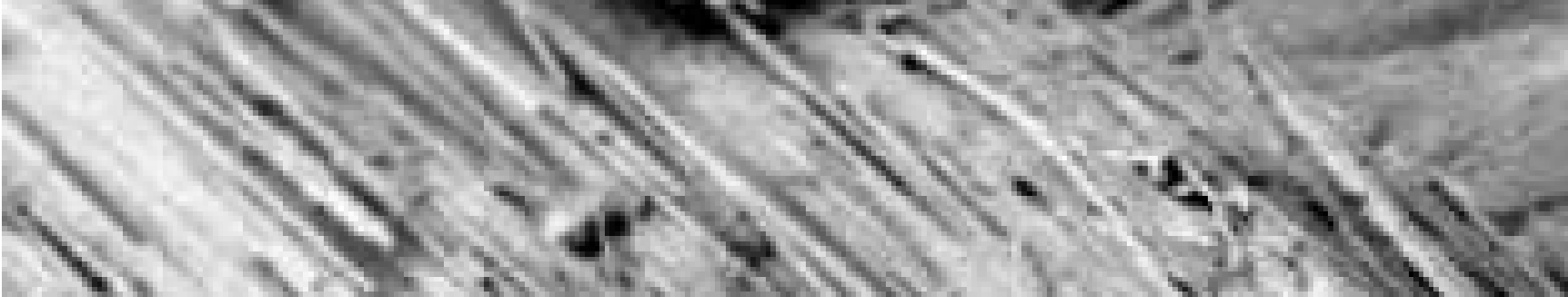

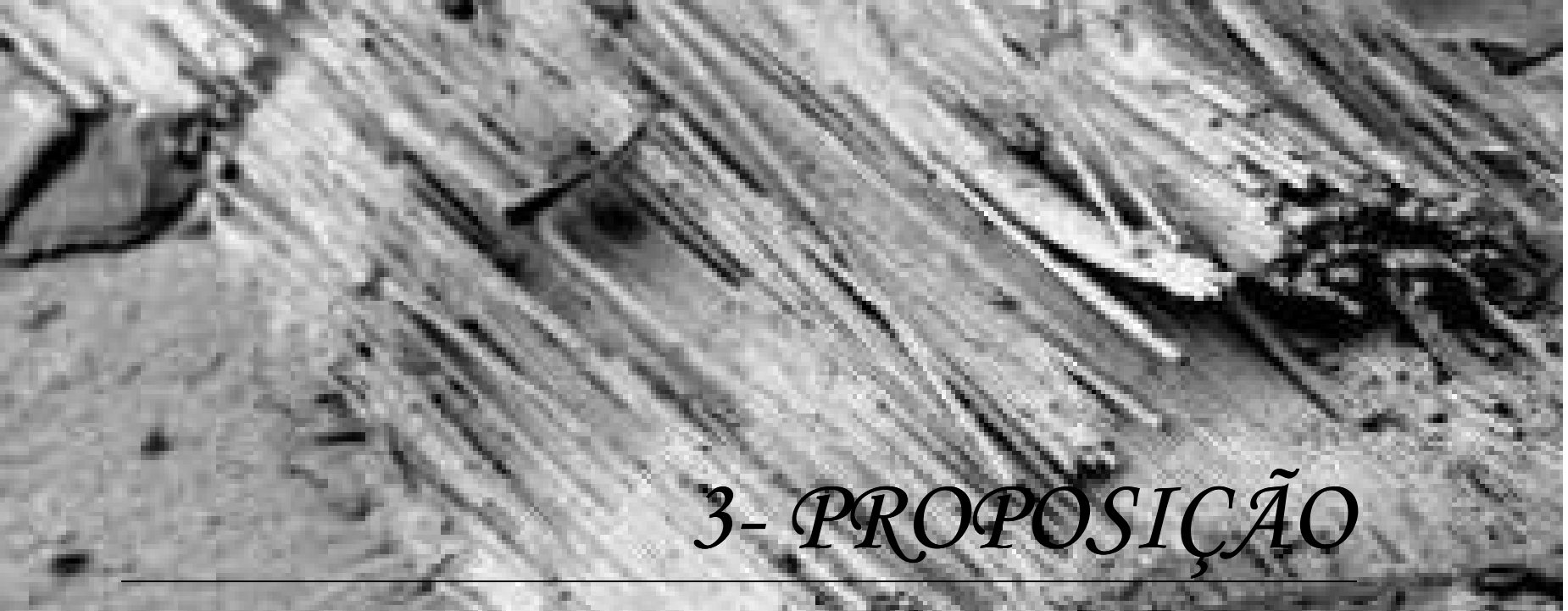

Ho

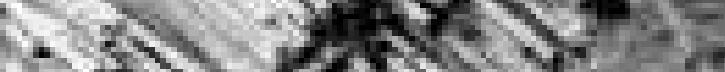

its

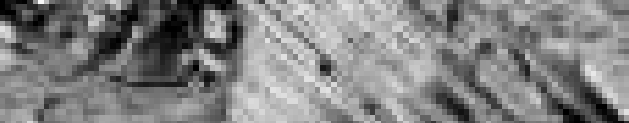

2.t.

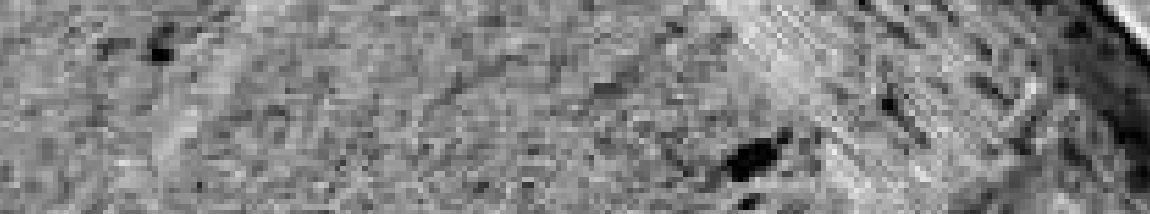

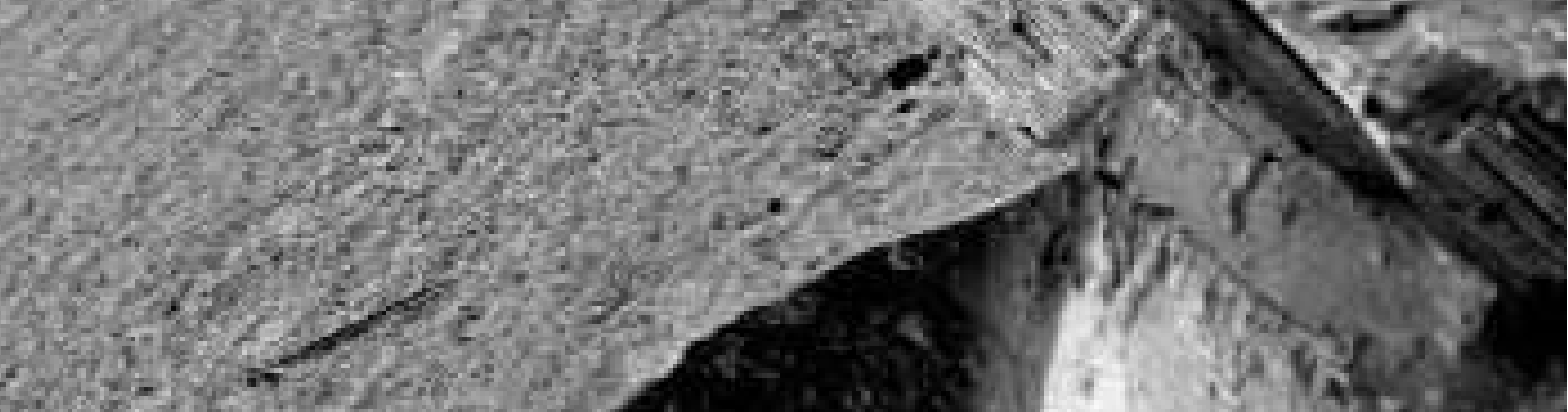




\section{3- PROPOSIÇÃO}

Este estudo tem por objetivo:

1. Verificar a influência do tipo de pino estético sobre a resistência à fratura do material restaurador coronário;

2. Verificar o tipo de interação ocorre entre estes materiais;

3. Qual o combinação pino/resina se comporta melhor frente às cargas compressivas que ocorrem durante os ensaios de tração diametral. 
W.

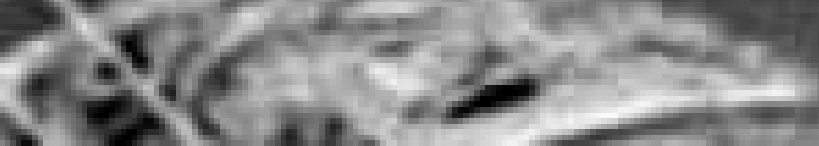

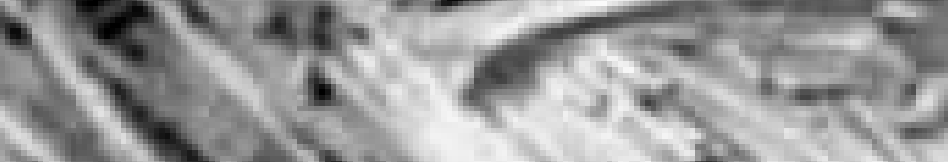

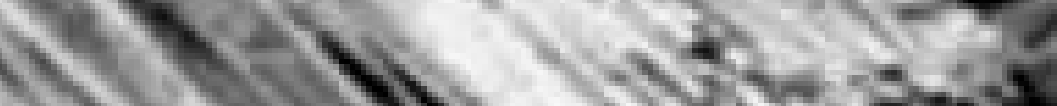

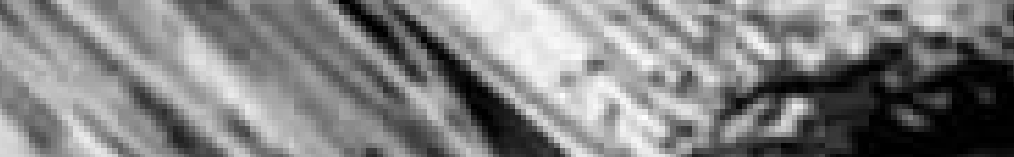

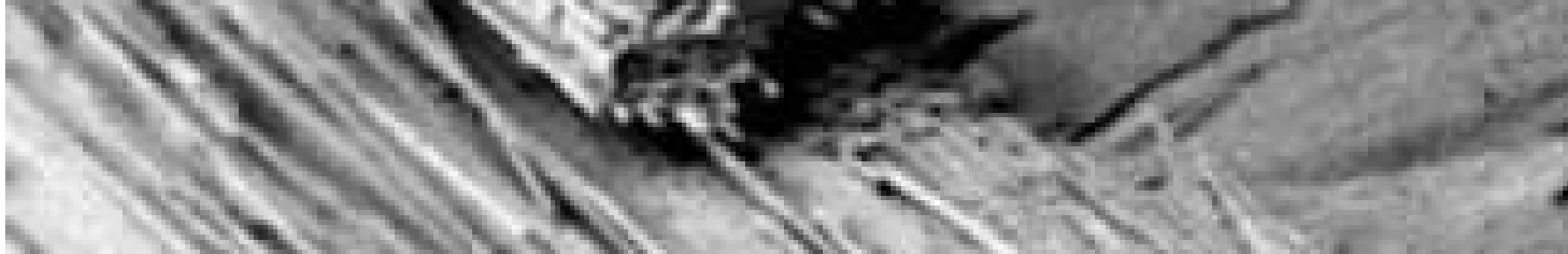

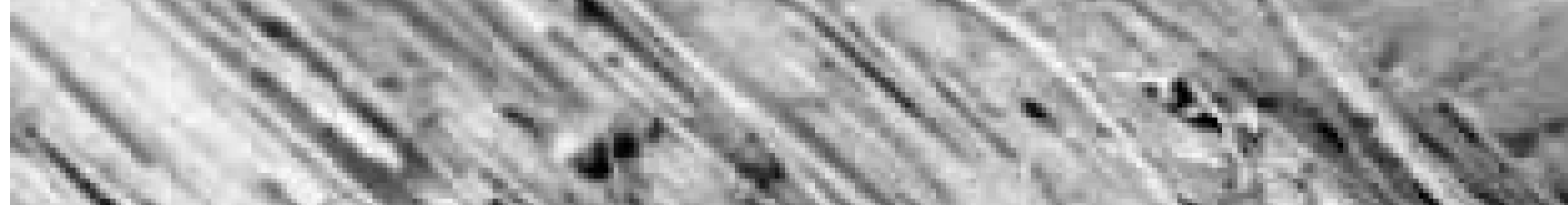

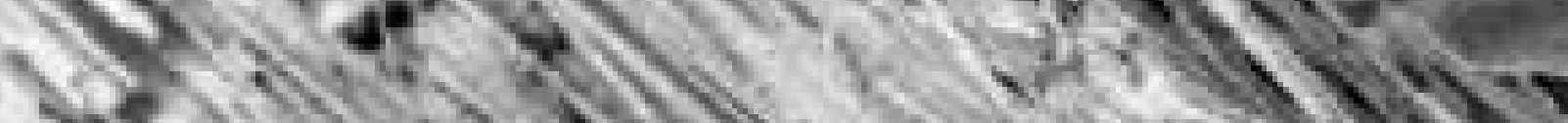

- 4- MATERIALE METODOS

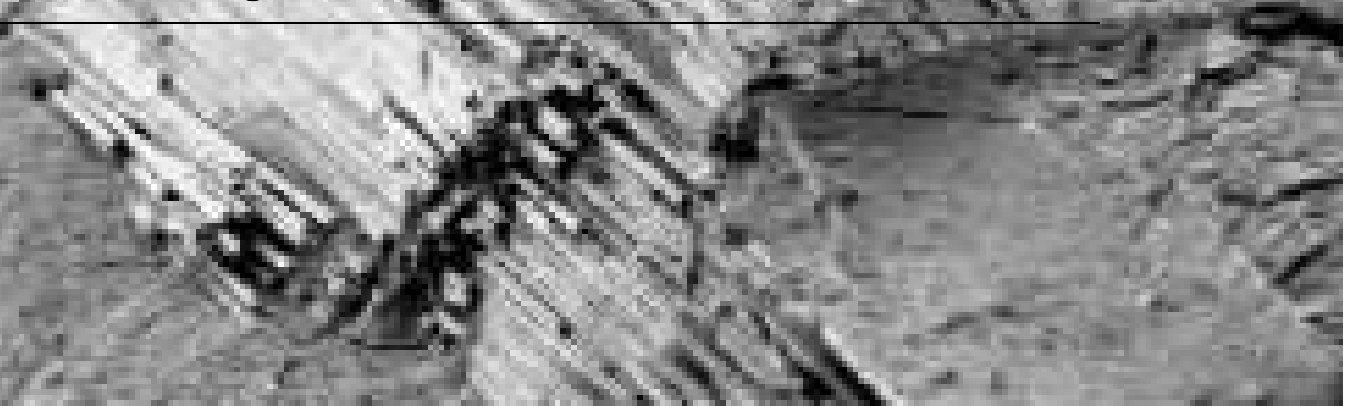

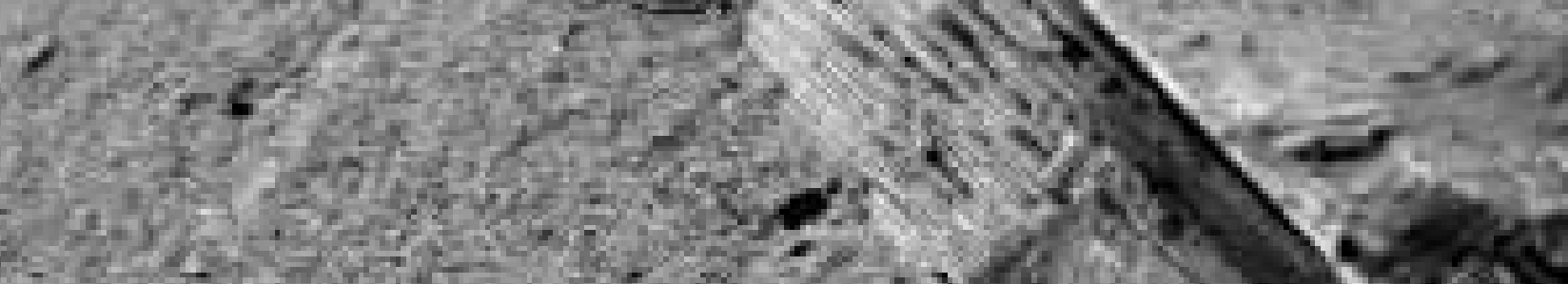


4- MATERIAL E MÉTODOS

4.1 MATERIAIS

4.1.1 Pinos Intra-Radiculares Pré-fabricados

Foram selecionados para este trabalho 5 marcas comerciais de pinos estéticos pré-fabricados e 1 marca comercial de pino pré-fabricado metálico, disponíveis no mercado Canadense(Figuras 4.1 e 4.2).

\begin{tabular}{|c|c|c|l|}
\hline Pinos & Sigla & Fabricante & \multicolumn{1}{|c|}{ Especificação } \\
\hline Vectris Post & A & Ivoclar-Vivadent & Diâmetro 2,0mm \\
\hline FibreKor Post & B & Jeneric/Pentron & Diâmetro 1,5mm \\
\hline Fstheti-Plus & C & Bisco & Diâmetro 1,35mm \\
\hline Light-Post & D & Bisco & Diâmetro 1,35mm \\
\hline Dentorama & E & Svenska Dentorama AB & Diâmetro 1,15mm \\
\hline ParaPost & F & Coltène/Whaledent & Diâmetro 1,5mm \\
\hline
\end{tabular}

Figura 4.1 - Quadro com as especificações dos pinos utilizados. 


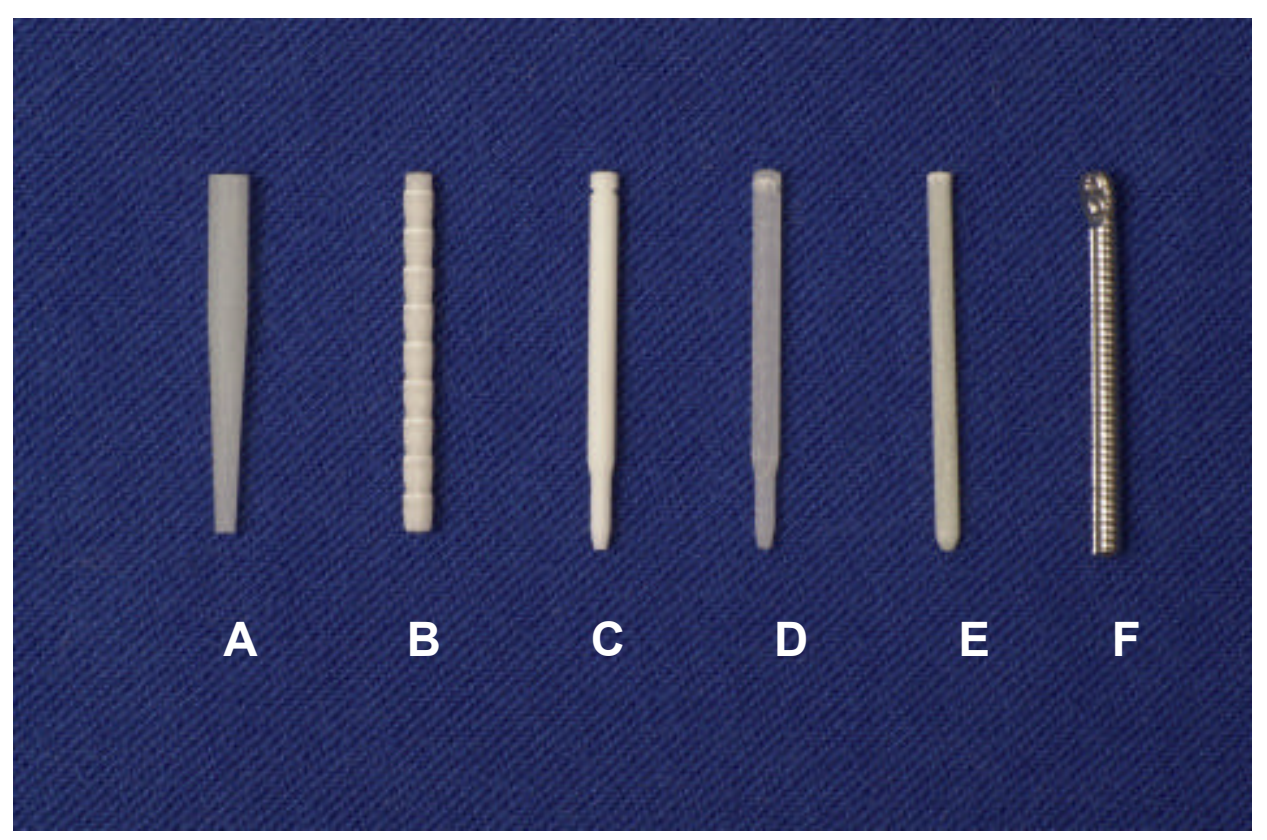

Figura 4.2 - Pinos pré-fabricados. A- Vectris-Post; B- Fibre-Post; C- ÆEsthetiPlus; D- Light-Post; E- Dentorama e F- ParaPost.

\subsubsection{Material de Preenchimento Coronário}

A porção coronária dos pinos foi confeccionada utilizando-se resina fotopolimerizável e agentes adesivos indicados pelo fabricante da resina (Figura 4.3). 


\begin{tabular}{|c|c|l|}
\hline Material & Fabricante & \multicolumn{1}{|c|}{ Especificação } \\
\hline Tetric Ceram & Ivoclar-Vivadent & $\begin{array}{l}\text { Lote D54812 } \\
\text { Validade 05-2007 }\end{array}$ \\
\hline $\begin{array}{c}\text { Monobond-S } \\
\text { Silano }\end{array}$ & Ivoclar-Vivadent & $\begin{array}{l}\text { Lote C24280 } \\
\text { Validade 03-2003 }\end{array}$ \\
\hline $\begin{array}{c}\text { Excite } \\
\text { Agente de União }\end{array}$ & Ivoclar-Vivadent & $\begin{array}{l}\text { Lote C08332 } \\
\text { Validade 08-2002 }\end{array}$ \\
\hline
\end{tabular}

Figura 4.3 - Quadro com a especificação do material de reconstrução coronária.

\subsubsection{Matriz Metálica}

Para este estudo foi confeccionada uma matriz de aço inoxidável (Figura 4.4A) formadas de duas partes: uma parte inferior (Figura 4.4B) de $80 \mathrm{~mm} \mathrm{X} 15$ $\mathrm{mm}$ com uma perfuração central de $2 \mathrm{~mm}$ para adaptação dos pinos Vectris e uma perfuração de $1,5 \mathrm{~mm}$ distando $20 \mathrm{~mm}$ do centro para adaptar os outros pinos; uma parte superior (Figura 4.4C) medindo $70 \mathrm{~mm}$ X $3 \mathrm{~mm}$ com perfuração central de $6 \mathrm{~mm}$ de diâmetro cujo centro coincide com o centro a perfuração para os pinos Vectris na base, uma perfuração de $6 \mathrm{~mm}$ de diâmetro coincidindo com a perfuração para os outros pinos e uma terceira perfuração, também de $6 \mathrm{~mm}$, para obtenção de padrões de resina composta. Esta porção superior da matriz foi dividida em duas partes iguais fixadas à parte inferior por meio de parafusos, para facilitar a remoção dos corpos de prova. 


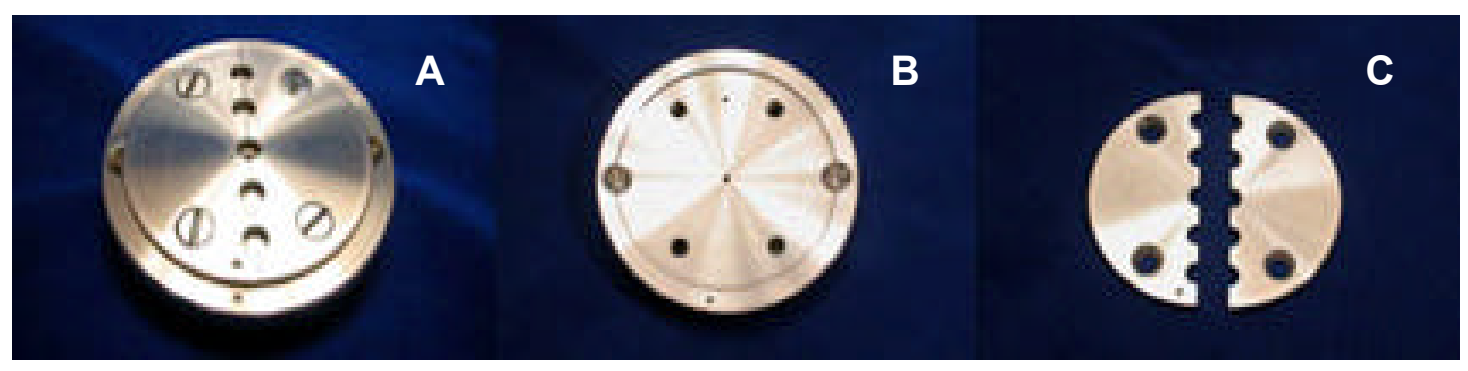

Figura 4.4 - Matriz metálica (A) com as porções inferior (B) e superior (C)

\subsection{INSTRUMENTOS, DISPOSITIVOS E MÉTODOS DE PESQUISA}

\subsubsection{Estudo Preliminar}

Escolhidos os pinos e o material de preenchimento coronário, estudos preliminares foram feitos para determinar a melhor maneira de avaliar a interação do material restaurador com os pinos pré-fabricados. Para este trabalho foi selecionado o teste de tração diametral (norma nํ27 da ADA ${ }^{1}$ ).

Um estudo piloto foi feito para a calibração do operador com as técnicas de confecção da porção coronária dos pinos e ensaios de tração diametral para corrigir possíveis falhas na execução da metodologia, para tanto foram utilizado 5 pinos para cada grupo estudado. Após o estudo piloto ficou fixada a utilização de 10 amostras para cada grupo. 


\subsubsection{Seleção dos Grupos}

Foram formados sete grupos:

Grupo 1 - composto de 10 discos de resina composta Tetric Ceram (IvoclarVivadent). (GRUPO CONTROLE) (Figura 4.5A)

Grupo 2 - composto de 10 pinos Vectris-Post (Ivoclar/Vivadent) de resina reforçada com fibras de vidro Ivoclar com porção coronária restaurada com resina composta Tetric Ceram (Ivoclar/Vivadent) (Figura 4.5B).

Grupo 3 - composto de 10 pinos Fibre-Post (Jeneric/Pentron) de resina reforçada com fibras de vidro com porção coronária restaurada com resina composta Tetric Ceram (Figura 4.5C).

Grupo 4 - composto de 10 pinos AEsthetic-Plus (Bisco) de resina reforçada com fibras de quartzo com porção coronária restaurada com resina composta Tetric Ceram (Figura 4.5D).

Grupo 5 - composto de 10 pinos Light-Post (Bisco) de resina reforçada com fibras de quartzo com porção coronária restaurada com resina composta Tetric Ceram (Figura 4.5E).

Grupo 6 - composto de 10 pinos Dentorama (Svenska Dentorama) de resina reforçada com fibras de vidro com porção coronária restaurada com resina composta Tetric Ceram (Figura 4.5F).

Grupo 7 - composto de 10 pinos metálicos ParaPost (Coltène/Whaledent) com porção coronária restaurada com resina composta Tetric Ceram (Figura 4.5G). 

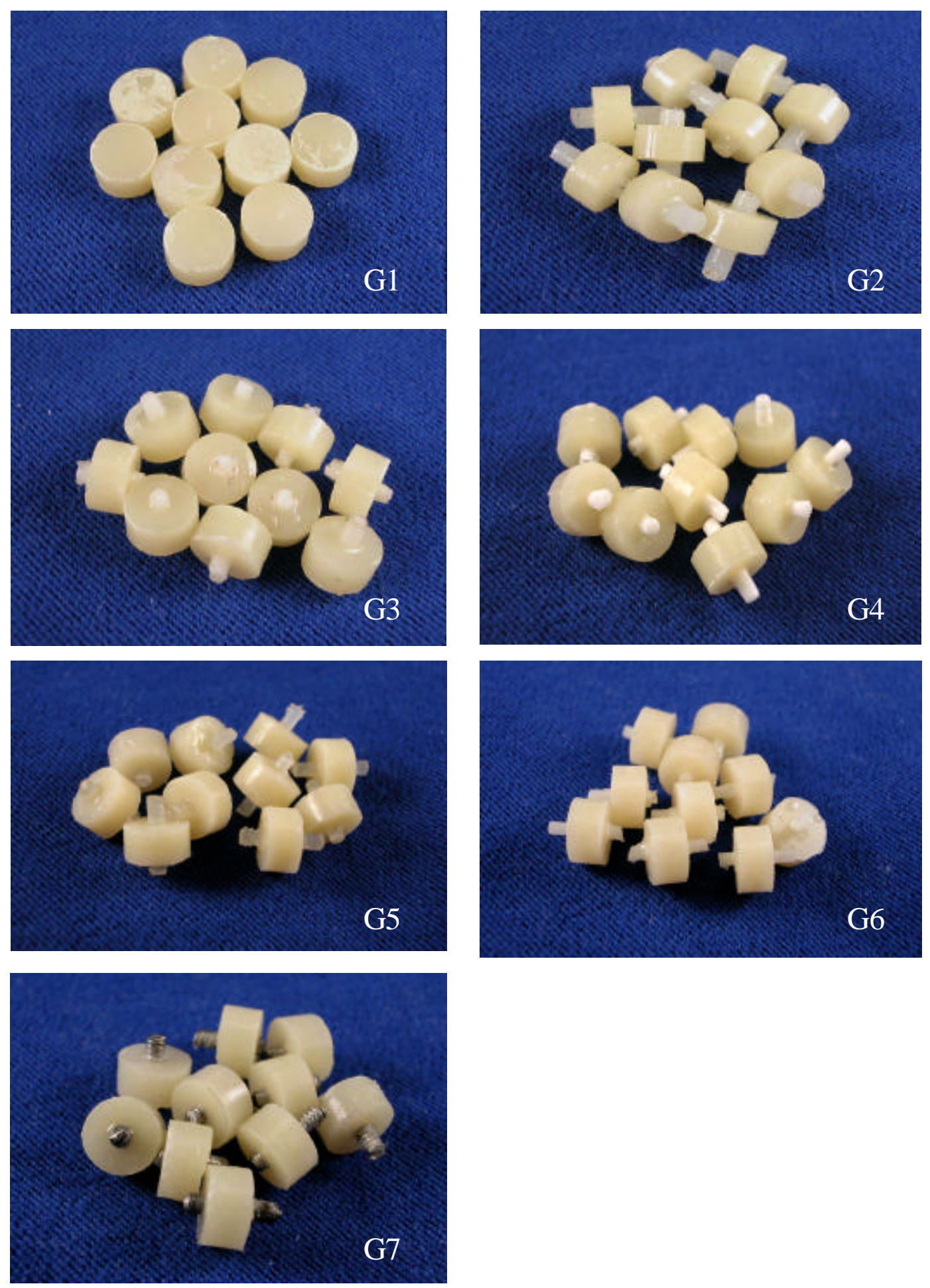

Figura 4.5 - Amostras dos grupos de estudo. G1- Tetric Ceram; G2- VectrisPost; G3- Fiber-Post; G4- Æsstheti-Plus; G5- Light-Post; G6- Dentorama e G7- ParaPost. 


\subsubsection{Obtenção dos Corpos de Prova}

Os corpos de prova foram obtidos com a utilização da matriz de aço inoxidável. Para o Grupo 1 (Controle) os discos de resina foram confeccionados pela colocação da resina fotopolimerizável no interior da matriz e fotoativação por 40 segundos com um aparelho fotopolimerizador ${ }^{1}$ com 800 $\mathrm{mW} / \mathrm{cm}^{2}$ de potência até obter-se um disco sólido de resina com as dimensões de $6 \mathrm{~mm} \times 3 \mathrm{~mm}$, conforme norma da ADA $\mathrm{n}^{\circ} 27^{1}$ para ensaios de tração diametral com resinas compostas. Após a remoção da matriz, os discos de resina foram fotopolimerizados mais uma vez em sua porção inferior por mais 40 segundos e armazenados em água destilada a $37^{\circ} \mathrm{C}$ em estufa ${ }^{2}$ durante 7 dias.

Os pinos utilizados no Grupo 2, foram limpos com auxílio de álcool etílico a $97 \%$ antes de receberem o tratamento superficial. Os fabricantes sugerem este procedimento para desengordurar a superfície do pino que pode estar contaminada pela manipulação. O tratamento de superfície foi realizado com aplicação do agente de silanização (Monobond $S$ - IvoclarVivadent) (Figura 4.6-A) por 60 segundos seguida da secagem do pino com jato de ar livre de contaminação. O agente de união (Excite - IvoclarVivadent) foi aplicado na porção coronária do pino (Figura 4.6-B), espalhado com leve jato de ar para evaporar o solvente remanescente e fotoativado por 40 segundos, sendo 20

\footnotetext{
${ }^{1}$ Optilux 501, n ${ }^{\circ}$ 5813289, SDS/Kerr, Danbury, CT, USA,

${ }^{2}$ Isotemp Incubator, modelo 630D, no 91100270 , Fisher Scientific, USA.
} 
segundos de cada lado do pino . O pino foi colocado na perfuração central da base da matriz de aço (Figura 4.6-C) e a porção central da matriz foi preenchida com resina composta Tetric Ceram e fotopolimerizada por 40 segundos unindo-a ao pino (Figura 4.6-D). Após a remoção da porção superior da matriz, os corpos de prova foram novamente polimerizados em sua porção inferior por mais 40 segundos e armazenados em água destilada a $37^{\circ} \mathrm{C}$ durante 7 dias.

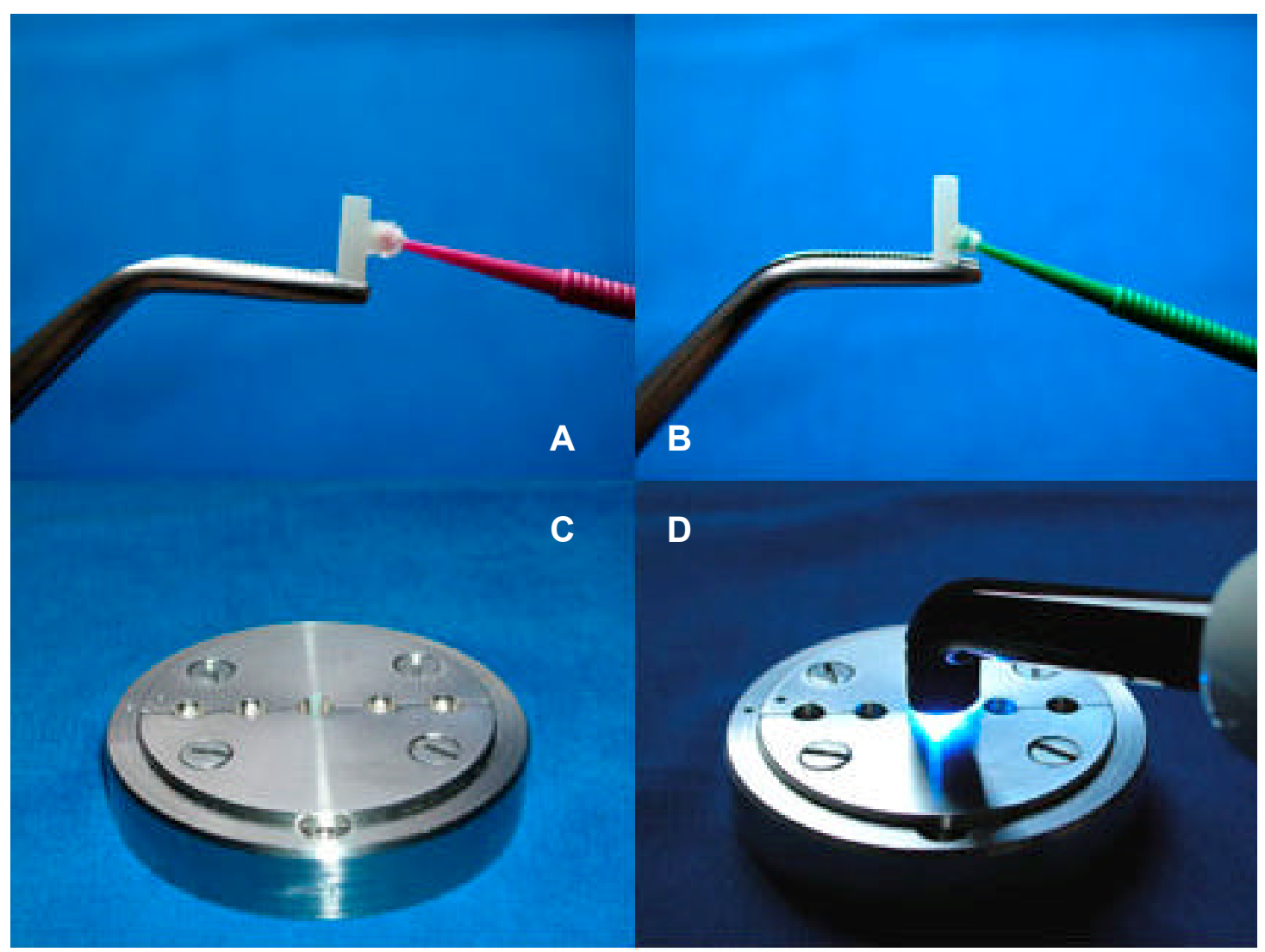

Figura 4.6 - Preparação de um corpo de prova. A- Aplicação do silano; BAplicação do agente de união; C- Posicionamento do pino na matriz e DFotopolimerização da amostra. 
O mesmo procedimento foi realizado nos pinos dos grupos 3, 4, 5, 6 e 7 sendo que tomou-se o cuidado de manter os pinos centralizados na matriz. Após a estocagem em água destilada, os corpos de prova foram conduzidos para o ensaio de tração diametral.

\subsubsection{Ensaios de Tração Diametral}

Os ensaios foram conduzidos em uma Máquina Universal de Ensaios ${ }^{3}$ com célula de carga de $2000 \mathrm{~kg}$ acoplada para a medição dos resultados (Figura 4.7). Os corpos de prova foram colocados na máquina de ensaios entre discos de papel absorvente umedecidos e duas plataformas planas com a maior medida (diâmetro do corpo de prova) no sentido vertical. (Figura 4.8).

A plataforma superior, acoplada à célula de carga, comprimiu os discos de resina até que estes fraturassem. Os dados foram registrados em computador com o programa LabView ${ }^{4}$ e enviados para análise estatística.

Os corpos de prova foram identificados (Figura 4.9) e levados para avaliação em microscopia eletrônica de varredura com o intuito de observar o tipo de fratura existente entre a resina composta e o pino.

\footnotetext{
${ }^{3}$ Instron, modelo 8501, $\mathrm{n}^{\mathrm{o}}$. C0134, Instron Corporation, Caton, Mass., USA.

${ }^{4}$ National Instruments Corporate, Austin, Texas, USA.
} 


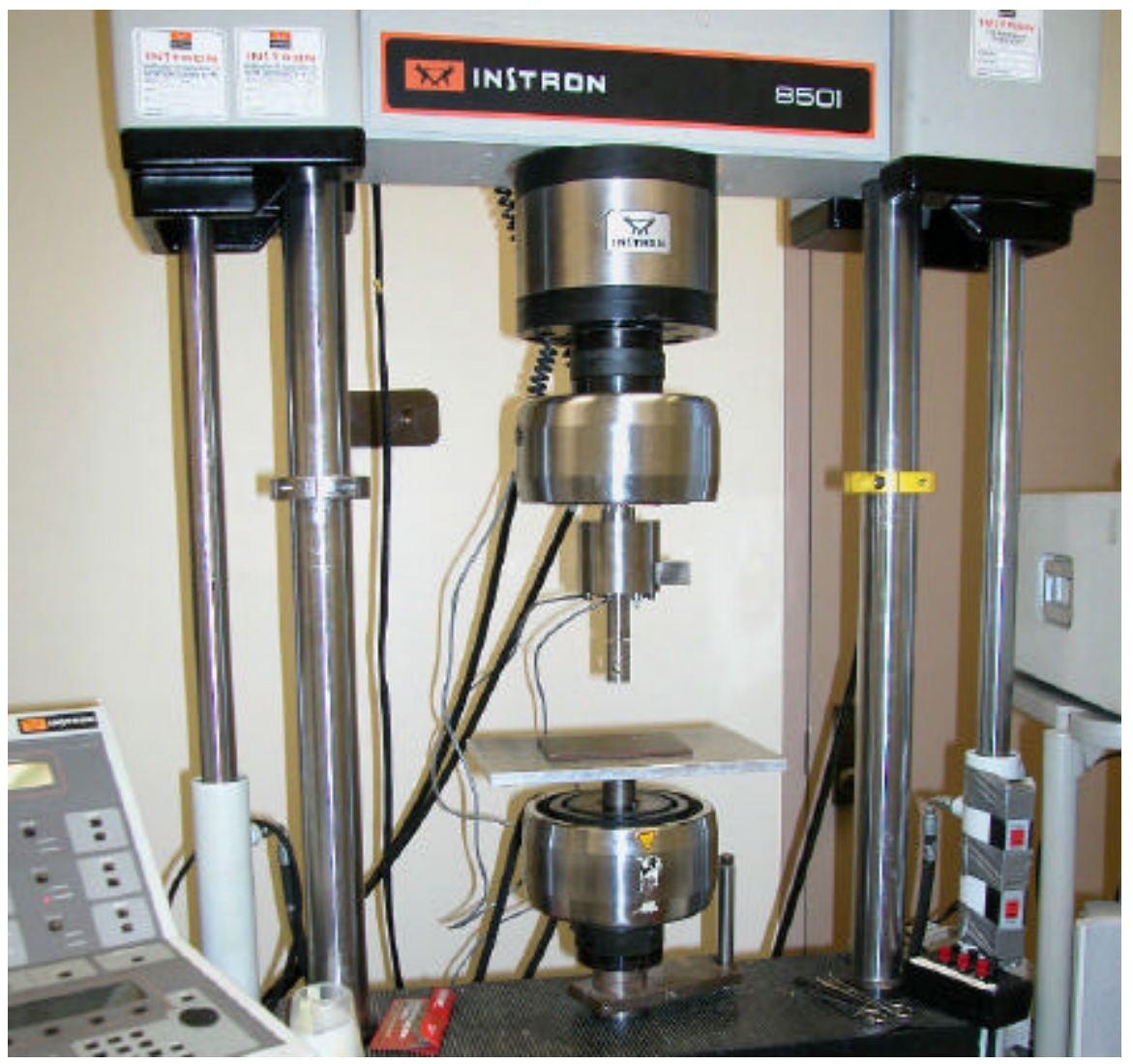

Figura 4.7 - Máquina de ensaio Instron 8501

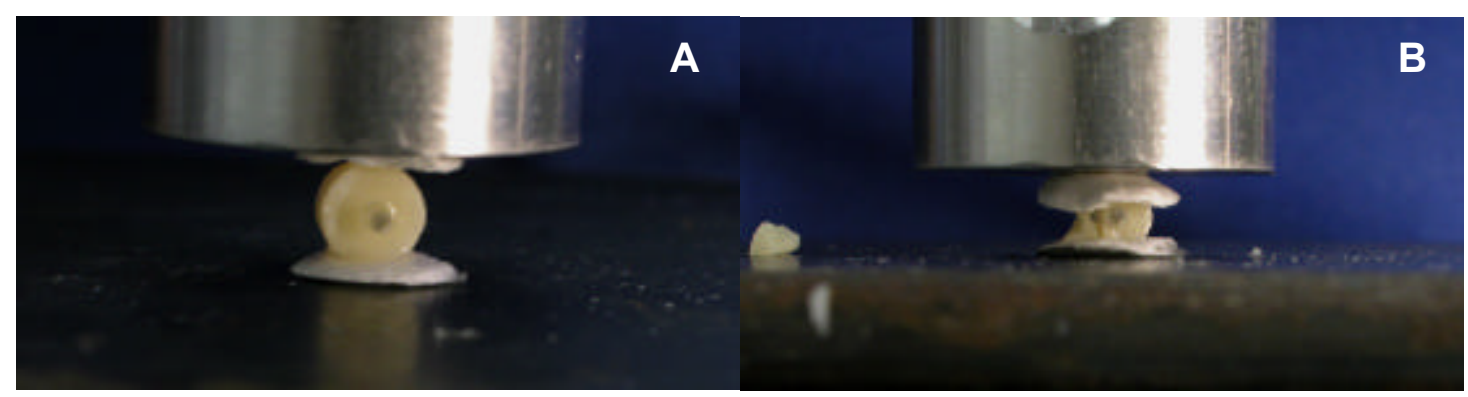

Figura 4.8 - Amostra antes do ensaio mecânico (A) e após o ensaio mecânico (B). 


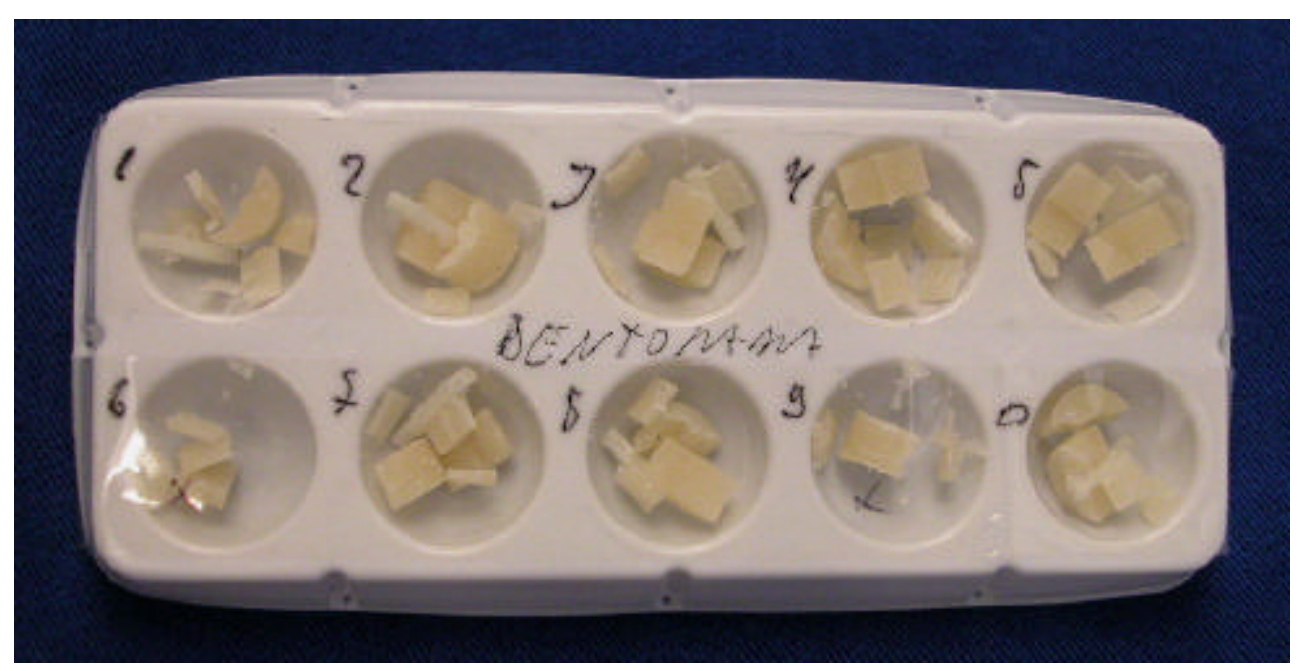

Figura 4.9 - Identificação dos corpos de prova.

\subsubsection{Microscopia Eletrônica de Varredura}

Após o ensaio mecânico foi selecionado de cada grupo os corpos de prova que apresentaram os valores extremos (maior e menor) para análise em microscopia eletrônica de varredura (MEV). Os espécimes foram colados em bases metálicas (Stubs) com auxílio de fita adesiva carbonada de dupla face Shintron ${ }^{5}$ e levados à unidade Polaron $^{6}$ de recobrimento a vácuo para serem cobertos com uma película de $6 \mathrm{~nm}$ de platina o que permite a visualização dos espécimes no microscópio. Os pinos intactos também foram recobertos por platina e observados em MEV para facilitar a avaliação dos espécimes após o ensaio destrutivo de tração diametral.

\footnotetext{
${ }^{5}$ Shinto Paint CO., LTD, Japan.

${ }^{6}$ Polaron SC515 SEM Coating System, Fisions Instruments, VG Microtec, Uckfield, England.
} 
Finalizado o recobrimento com platina (Figura 4.10A), os espécimes foram analisados no Microscópio Eletrônico de Varredura Hitachi ${ }^{7}$ S-2500 (Figura 4.10B) com voltagem de aceleração de $10 \mathrm{KV}$ e com as magnificações de $50 \mathrm{X}, 100 \mathrm{X}$ e $500 \mathrm{X}$

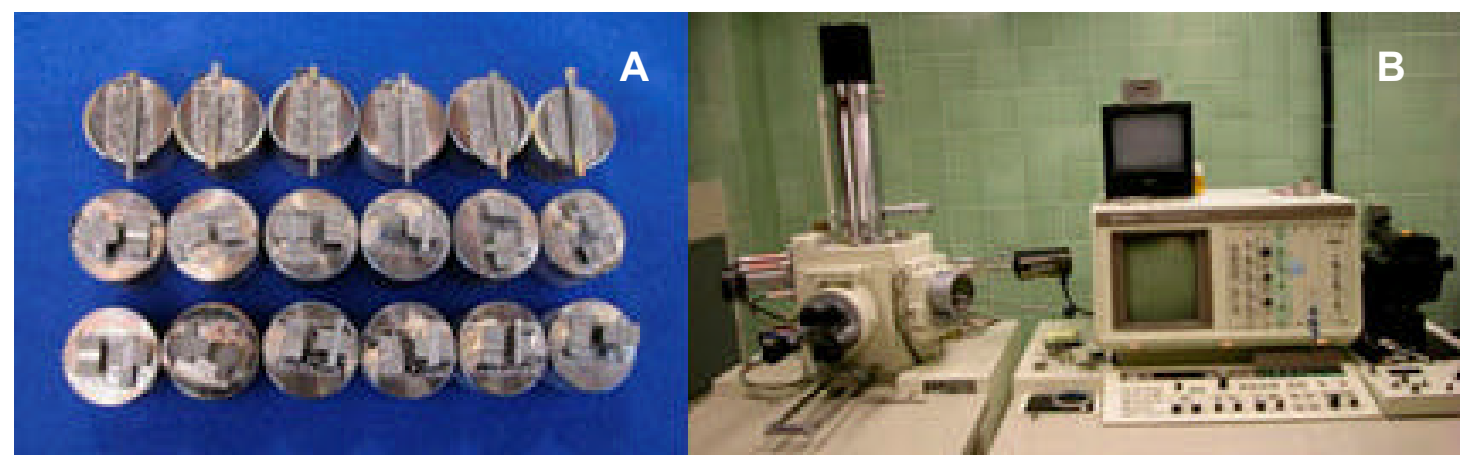

Figura 4.10 - Amostras preparadas para microscopia eletrônica de varredura (A) e microscópio eletrônico de varredura Hytachi S2500 - torre de vácuo e plataforma de comando (B).

As leituras foram realizadas nas duas porções fraturadas dos espécimes com o objetivo de verificar a forma como a fratura se apresentou e qual dano esta causou aos pinos reforçados por fibra. As imagens obtidas foram gravadas para posterior avaliação.

\footnotetext{
${ }^{7}$ Scanning Electron Microscope S-2500, Hitachi LTD, Tokyo, Japan.
} 


\subsubsection{Análise Estatística}

Os dados foram contabilizados e submetidos à análise estatística utilizando-se a Análise de Variância (ANOVA). Como esta análise demonstrou haver diferenças entre os grupos, o teste de Tukey foi empregado para determinar quais grupos apresentavam diferenças estatisticamente significantes. 
W.

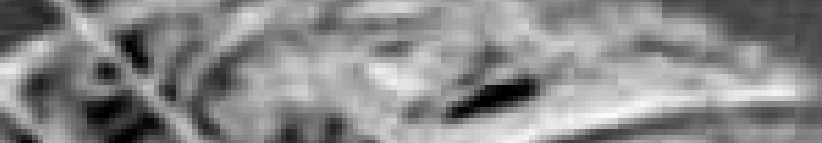

19.

$4-2 \sin 2$

N W W

$1 \times 1$.

N W y y

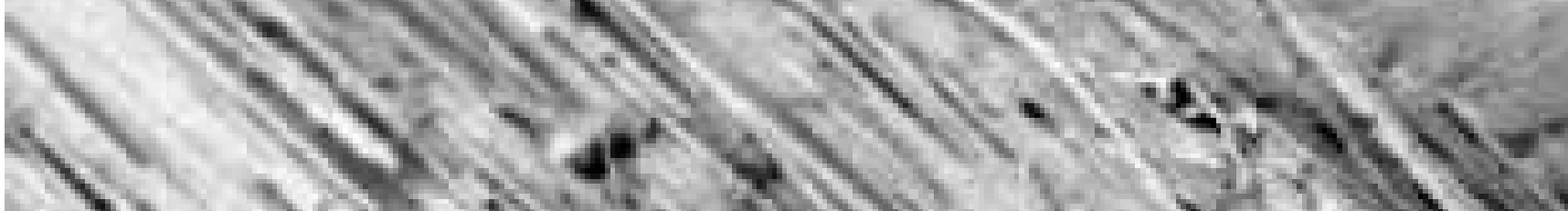

Nat 1 H

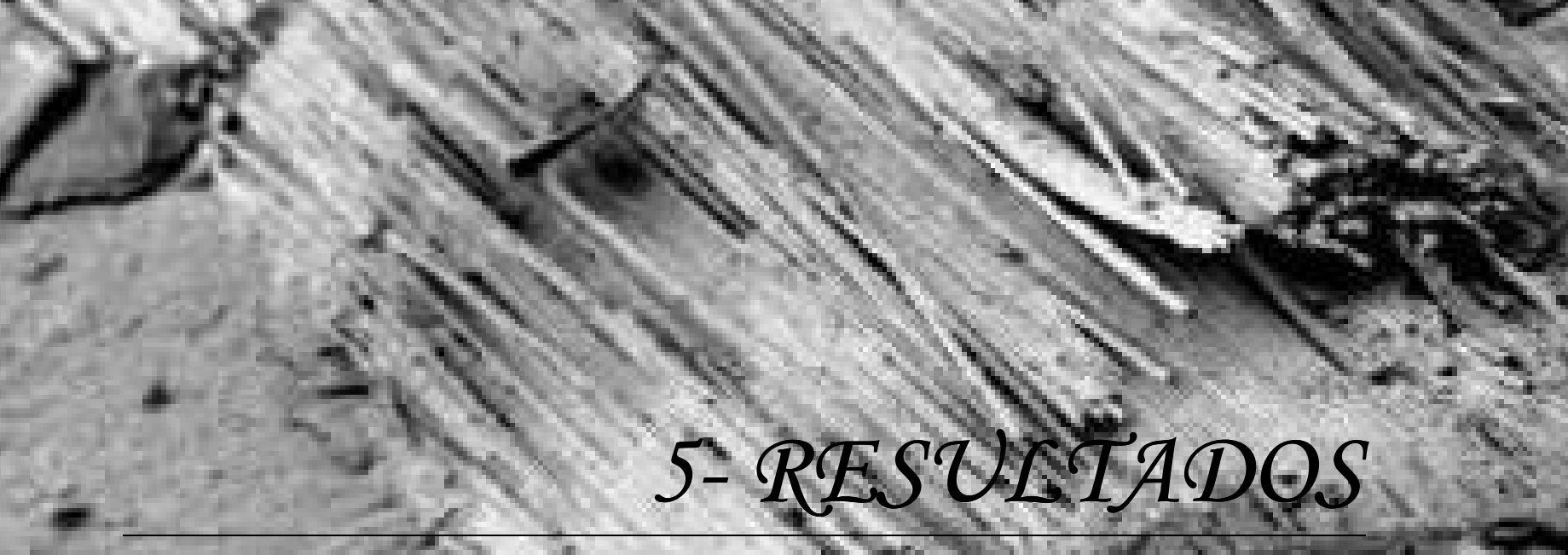

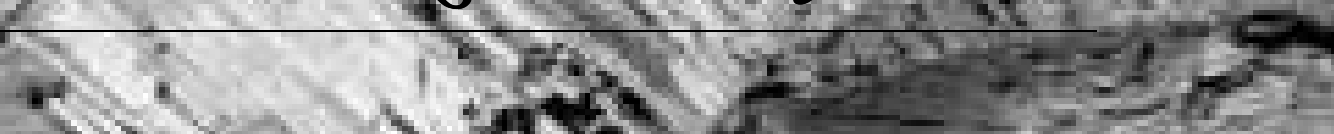

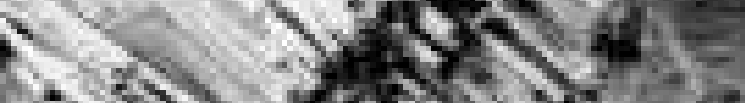

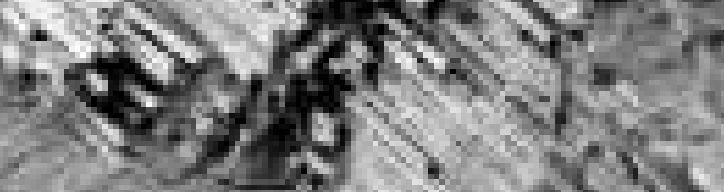

qyis

$4+6 c^{2}$

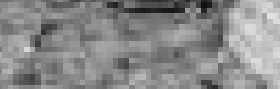

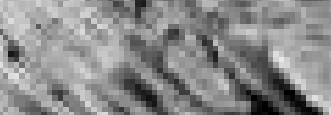

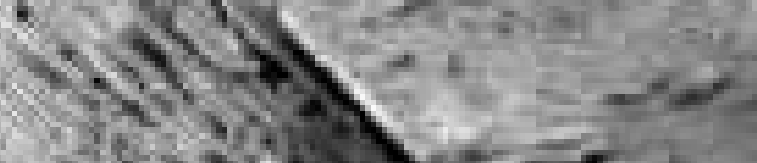

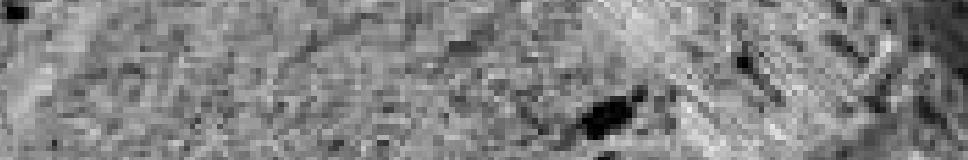




\section{5- RESULTADOS}

Para facilitar a leitura, os resultados foram divididos em resultados do teste de tração diametral e análise das imagens obtidas em microscopia eletrônica de varredura.

5.1 Resultados da Tração Diametral

As principais medidas dos ensaios mecânicos estão relacionadas abaixo (Tabela 5.1). Os dados referem-se à resistência ao teste de tração diametral (MPa) para cada um dos sete grupos estudados.

Tabela 5.1 - Médias e desvio padrão dos resultados de resistência à tração diametral (MPa) dos grupos de 1 a $7 . n=10$.

\begin{tabular}{ccc}
\hline GRUPOS & MÉDIA & DESVIO PADRÃO \\
\hline G 1 & 49,64 & 3,36 \\
G 2 & 29,77 & 3,36 \\
G 3 & 31,90 & 2,39 \\
G 4 & 28,92 & 2,20 \\
G 5 & 34,26 & 3,37 \\
G 6 & 33,45 & 2,46 \\
G 7 & 27,90 & 2,40 \\
\hline
\end{tabular}


Os resultados referentes aos testes de tração diametral descritos na Tabela 5.1 foram submetidos à análise de variância a um critério (ANOVA) para avaliar a possibilidade de diferenças estatisticamente significantes entre as condições testadas (Tabela 5.2).

Tabela 5.2 - Dados do teste estatístico de análise de variância a um critério obtidos dos ensaios de tração diametral.

\begin{tabular}{c|c|c|c|c}
\hline EFEITO & $\begin{array}{c}\text { Graus de } \\
\text { liberdade }\end{array}$ & $\begin{array}{c}\text { Soma dos } \\
\text { quadrados }\end{array}$ & $\mathbf{F}$ & $\mathbf{P}$ \\
\hline Entre grupos & 6 & 3296,43012 & 68,11393 & $<0,001$ \\
\hline
\end{tabular}

A análise de variância mostrou haver diferença estatisticamente significante entre os grupos testados. Para fazer as comparações múltiplas entre os grupos analisados, os dados foram submetidos ao Teste de Tukey a $5 \%$ (Tabela 5.3). 
Tabela 5.3 - Teste de Tukey para comparação múltipla entre os grupos testados. Nível de significância $=5,00 \%$.

\begin{tabular}{|c|c|c|c|c|c|c|c|}
\hline Comparação & G1 & G2 & G3 & G4 & G5 & G6 & G7 \\
\hline G1 & & $19,876^{*}$ & $17,739 *$ & $20,717^{*}$ & $15,383^{*}$ & $16,188^{*}$ & $21,74^{*}$ \\
\hline G2 & * & & $\begin{array}{c}-2,137 \\
\text { (ns) }\end{array}$ & $\begin{array}{c}0,814 \\
\text { (ns) }\end{array}$ & $-4,493^{*}$ & $\begin{array}{c}-3,688 \\
\text { (ns) }\end{array}$ & $\begin{array}{c}1,864 \\
\text { (ns) }\end{array}$ \\
\hline G3 & * & (ns) & & $\begin{array}{c}2,978 \\
\text { (ns) }\end{array}$ & $\begin{array}{c}-2,356 \\
\text { (ns) }\end{array}$ & $\begin{array}{r}-1,551 \\
\text { (ns) }\end{array}$ & $4,001^{*}$ \\
\hline G4 & * & (ns) & (ns) & & $-5,334^{*}$ & $-4,529^{*}$ & $\begin{array}{c}1,023 \\
\text { (ns) }\end{array}$ \\
\hline G5 & * & * & (ns) & * & & $\begin{array}{c}0,805 \\
\text { (ns) }\end{array}$ & $6,357^{*}$ \\
\hline G6 & * & (ns) & (ns) & * & (ns) & & $5,552^{*}$ \\
\hline G7 & * & (ns) & * & (ns) & * & * & \\
\hline
\end{tabular}

valor crítico $(3,86889682)$

* - diferença estatisticamente significante $(p<0,001)$

(ns) - diferença estatisticamente não significante

Para melhor visualização dos resultados, foi confeccionado um gráfico com as médias dos grupos, em ordem de valores decrescente, demonstrando as resistências dos diferentes grupos às cargas impostas em MPa (Figura 5.1). 


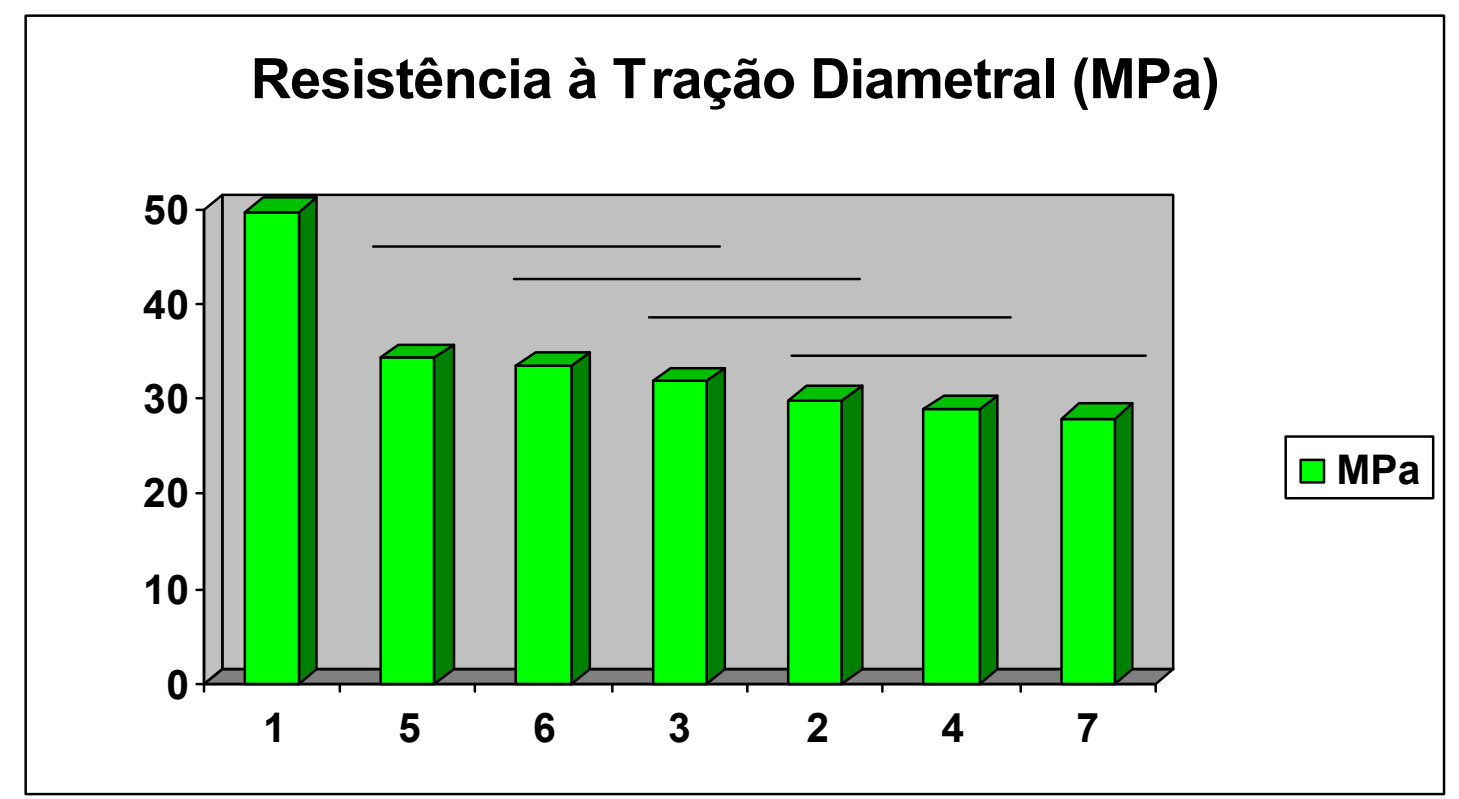

Figura 5.1 - Gráfico dos valores médios da resistência à tração diametral dos grupos em ordem decrescente e comparação estatística entre grupos. Os valores ligados por barras representam grupos sem diferença estatística.

5.2 Resultados da Microscopia Eletrônica de Varredura

Inicialmente, todos os pinos foram avaliados, da maneira que vieram dos fabricantes, para avaliação das características superficiais. A seguir, foram analisadas as imagens dos espécimes, após os ensaios, com aumentos de 50 X; 100 X e 500 X para a visualização do padrão ou característica da fratura entre a resina composta e o pino. As imagens obtidas (Figuras 5.2 a 5.7) revelaram que os pinos reforçados por fibras apresentam características superficiais muito semelhantes, com exceção do pino Fibre-Post (Figura 5.2) 
que apresenta forma de retenção distinta em relação aos demais. O tamanho das fibras de reforço também se manteve igual entre todos os pinos estudados.

O padrão de fratura apresentado pelos grupos restaurados com pinos reforçados por fibras demonstrou que houve fratura do tipo coesiva, com uma boa interação entre o material de composição dos pinos e a resina composta. O grupo restaurado com o pino metálico (Figura 5.7) apresentou fratura adesiva, demonstrando uma baixa qualidade de adesão entre a resina composta e o metal. 


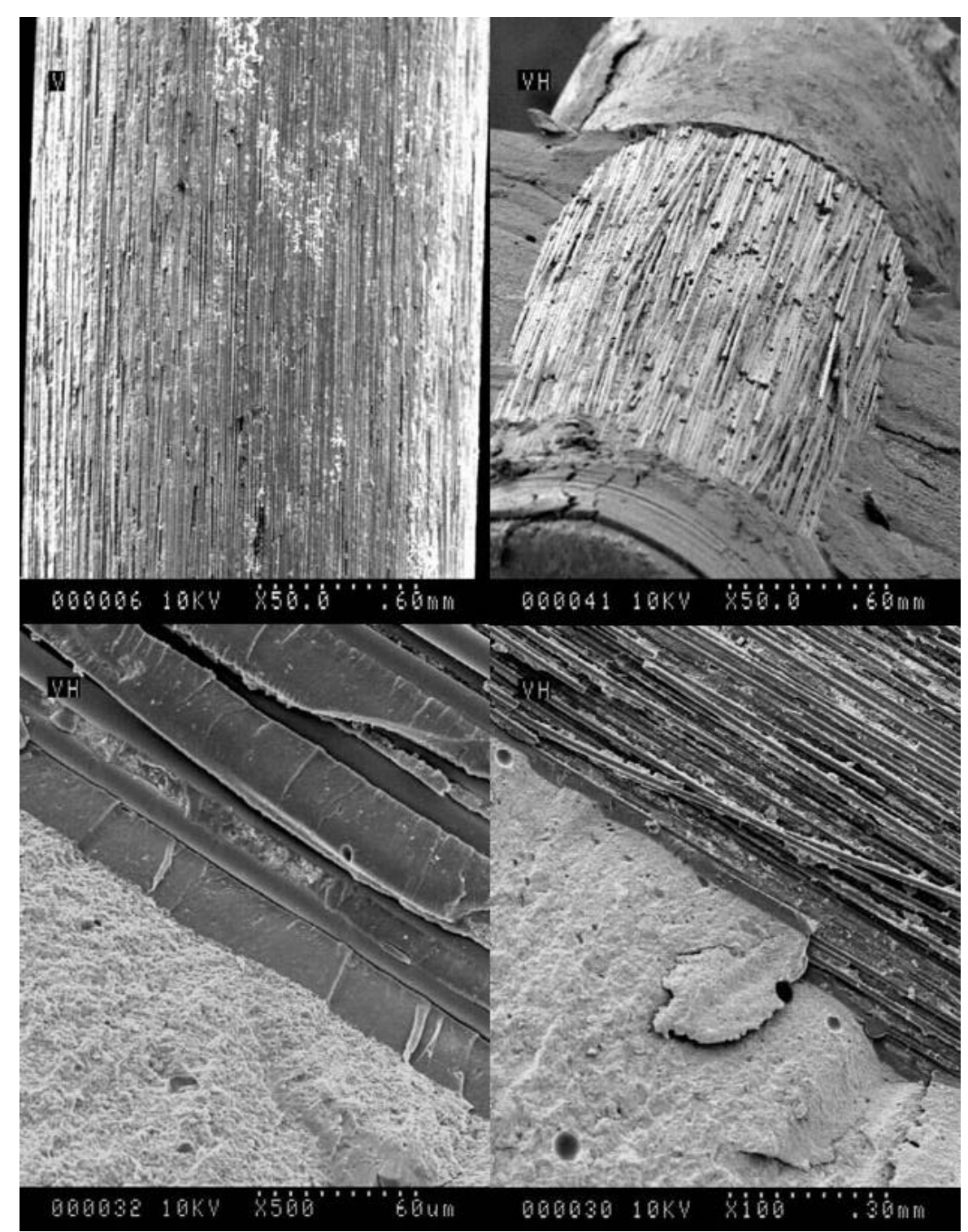

Figura 5.2 - Fotomicrografia do pino representante do Grupo 2. No sentido horário: Superfície do pino; padrão de fratura; aumento de $100 \mathrm{X}$ e aumento de $500 \mathrm{X}$. 


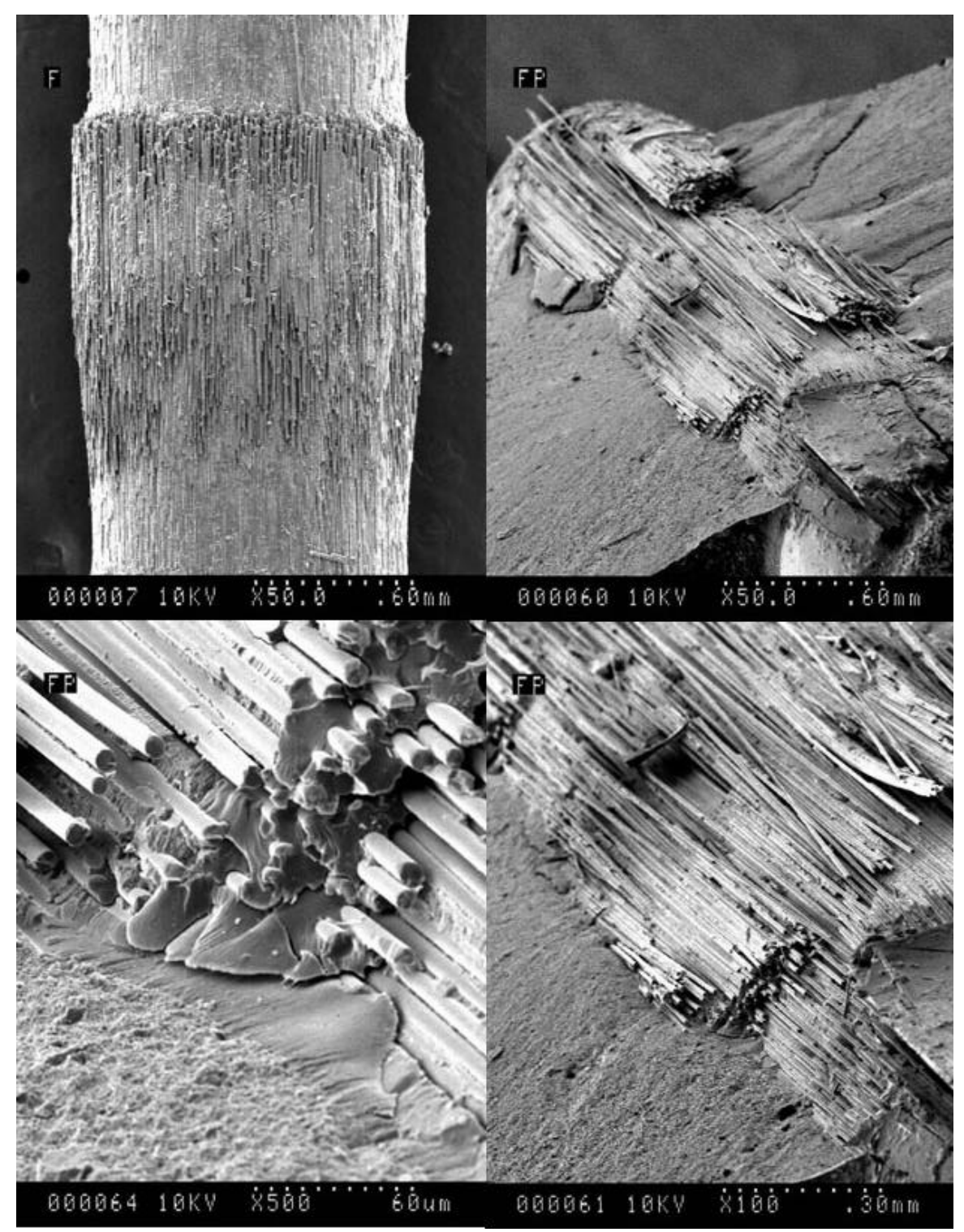

Figura 5.3 - Fotomicrografia do pino representante do Grupo 3. No sentido horário: Superfície do pino; padrão de fratura; aumento de $100 \mathrm{X}$ e aumento de $500 \mathrm{X}$. 


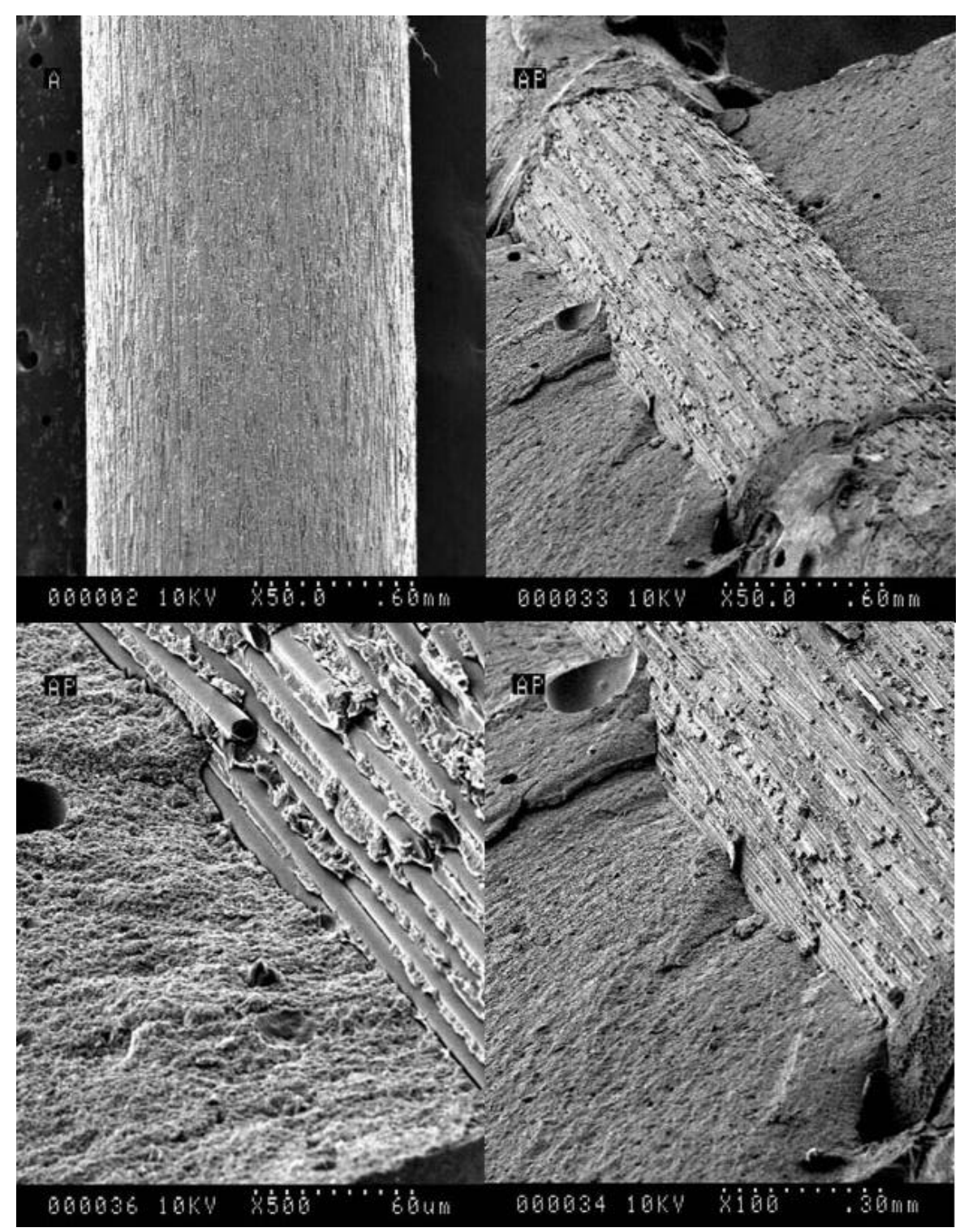

Figura 5.4 - Fotomicrografia do pino representante do Grupo 4. No sentido horário: Superfície do pino; padrão de fratura; aumento de $100 \mathrm{X}$ e aumento de $500 \mathrm{X}$. 


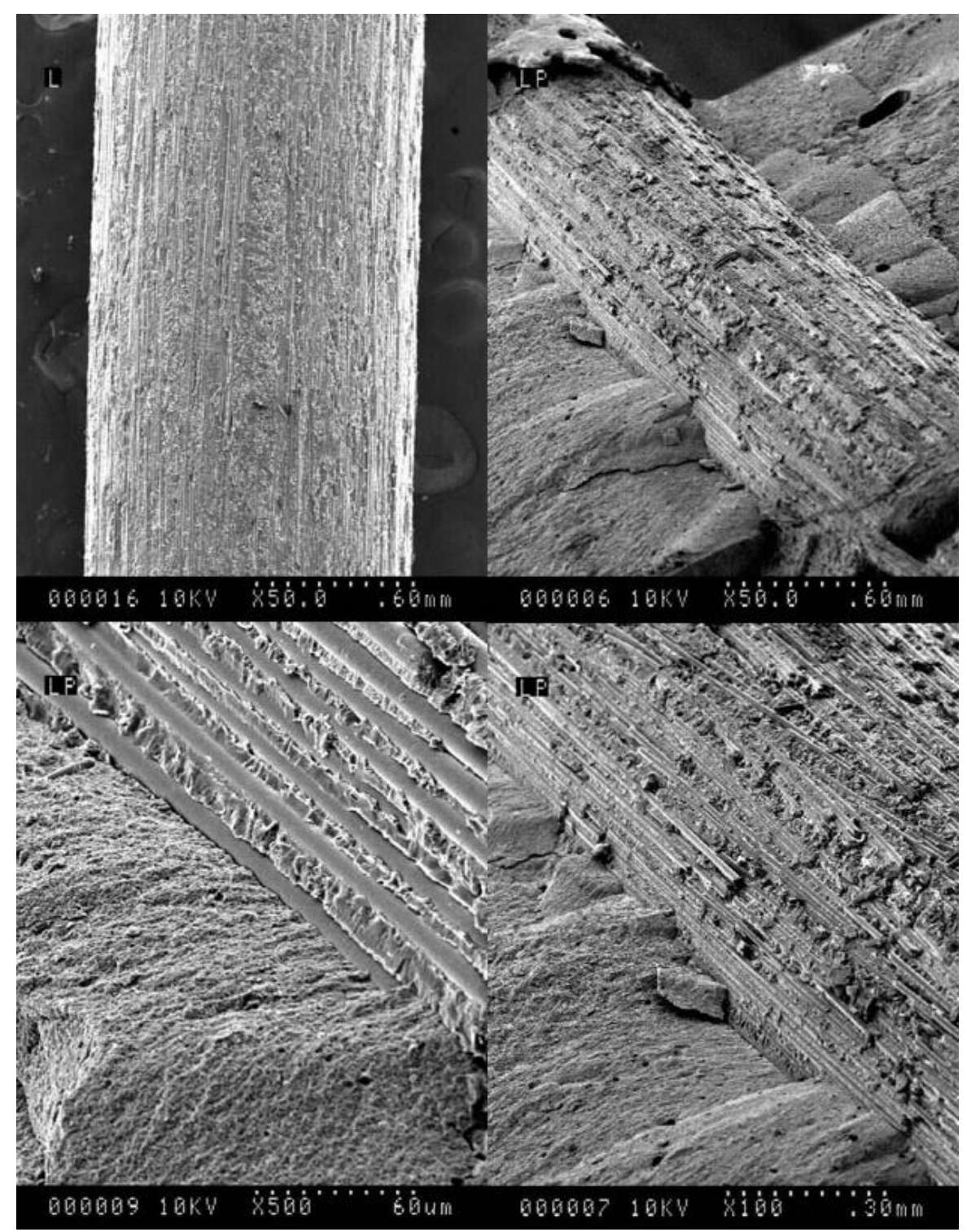

Figura 5.5 - Fotomicrografia do pino representante do Grupo 5. No sentido horário: Superfície do pino; padrão de fratura; aumento de $100 \mathrm{X}$ e aumento de $500 \mathrm{X}$. 


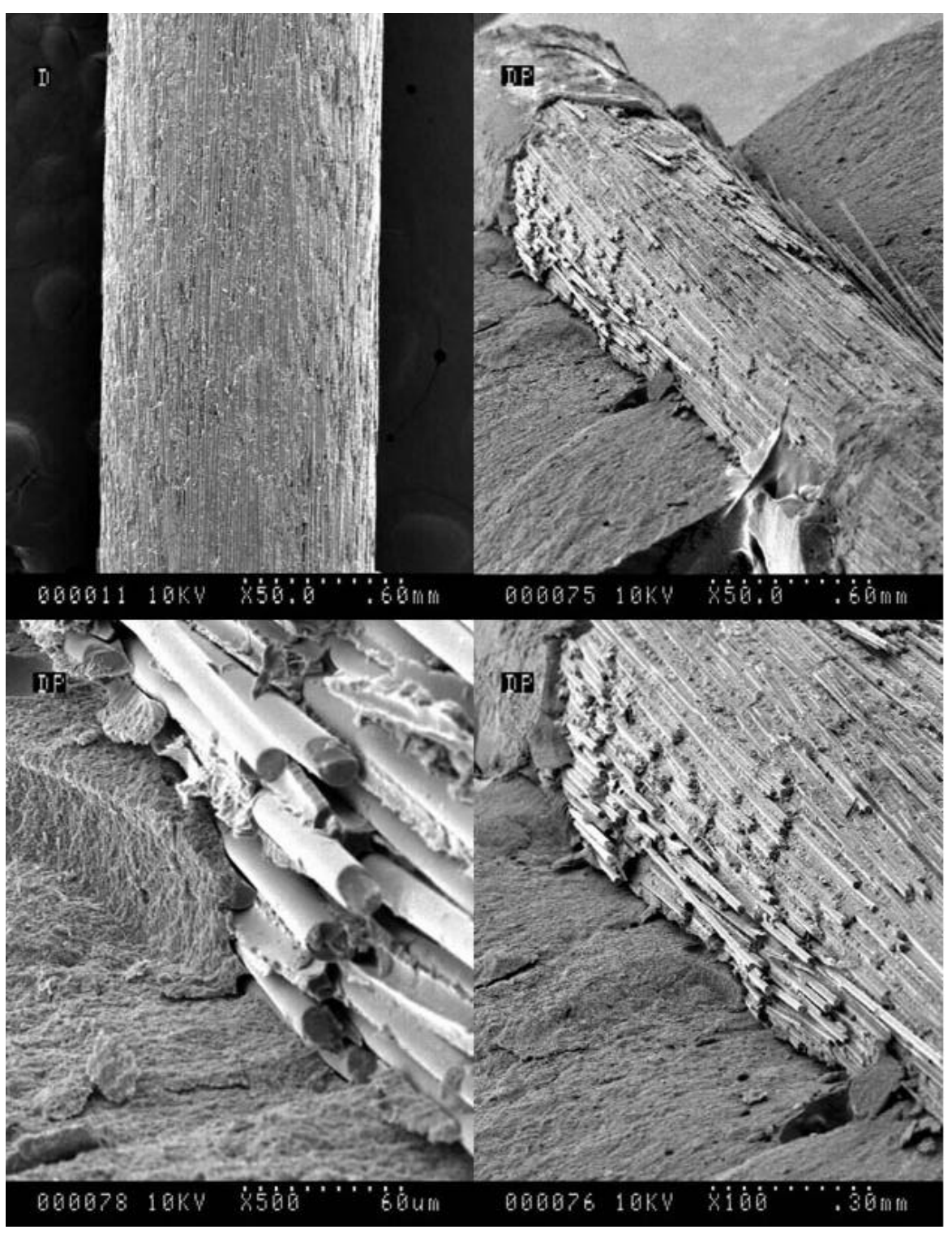

Figura 5.6 - Fotomicrografia do pino representante do Grupo 6. No sentido horário: Superfície do pino; padrão de fratura; aumento de $100 \mathrm{X}$ e aumento de $500 \mathrm{X}$. 


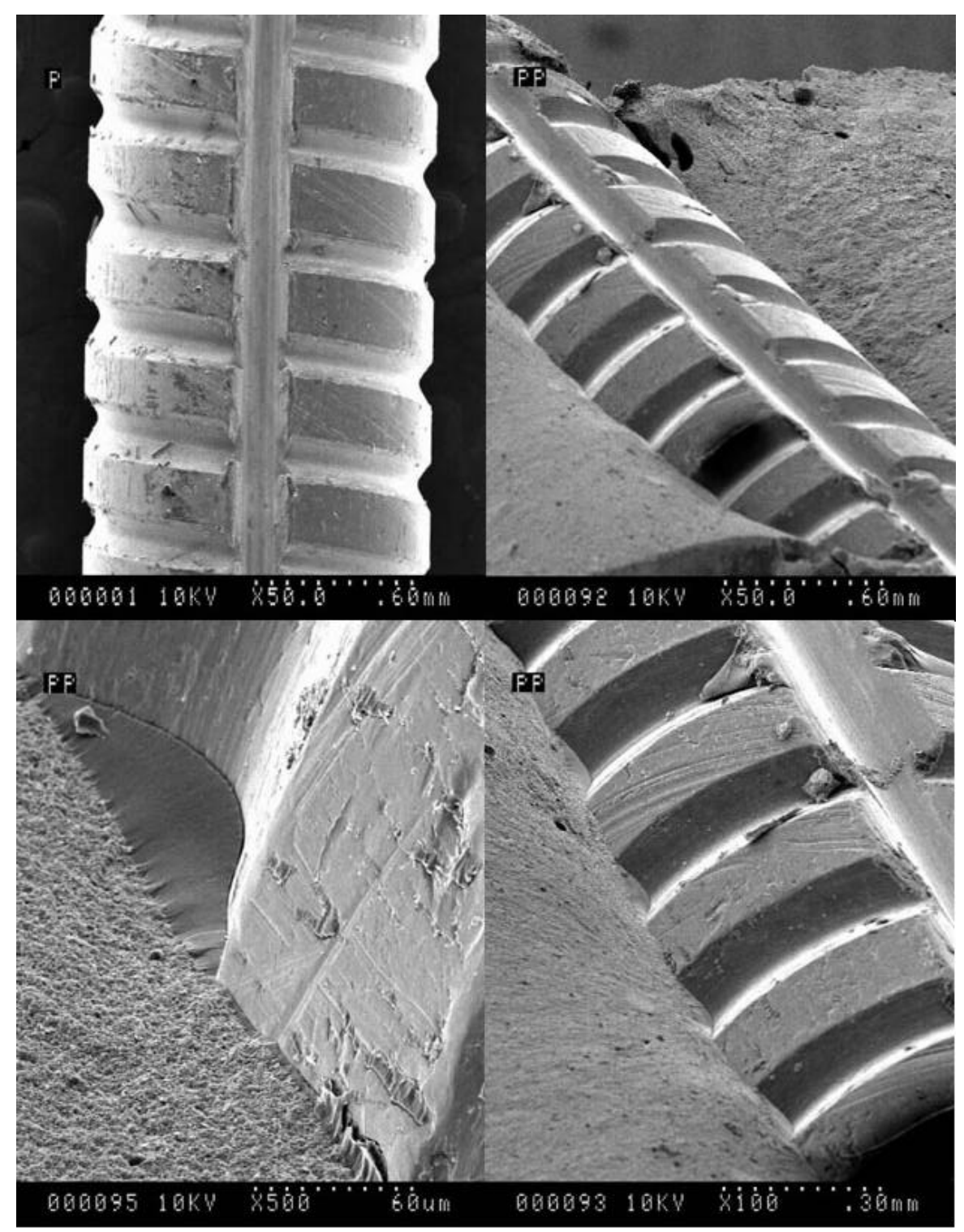

Figura 5.7 - Fotomicrografia do pino representante do Grupo 7. No sentido horário: Superfície do pino; padrão de fratura; aumento de $100 \mathrm{X}$ e aumento de $500 \mathrm{X}$. 
A análise comparativa das imagens entre os espécimes do mesmo grupo que apresentaram menor e maior valor de resistência ao teste de tração diametral, revelou que a diferença estava na espessura da película do agente de união. Quanto maior a película, menor a resistência à compressão e viceversa (Figuras 5.8 a 5.13).

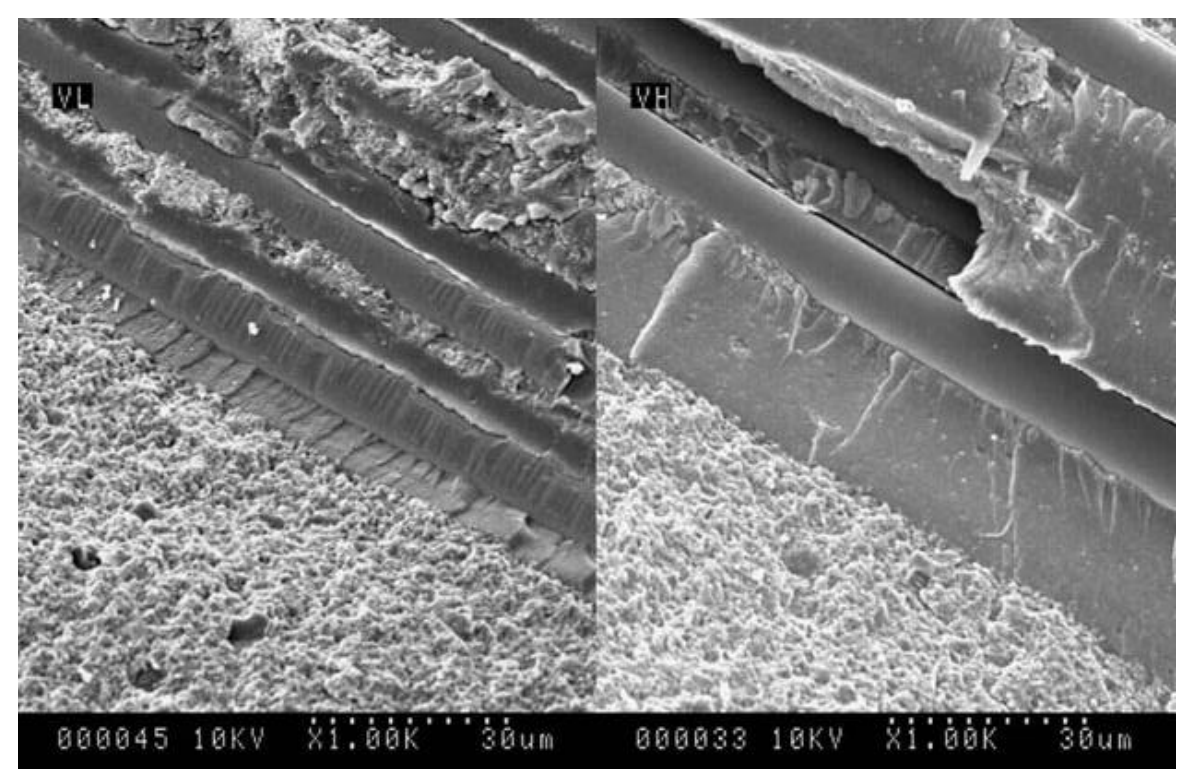

Figura 5.8 - Fotomicrografia do pino representante do Grupo 2. Espécimes com maior e menor valor, respectivamente. Aumento de $1000 \mathrm{X}$. 


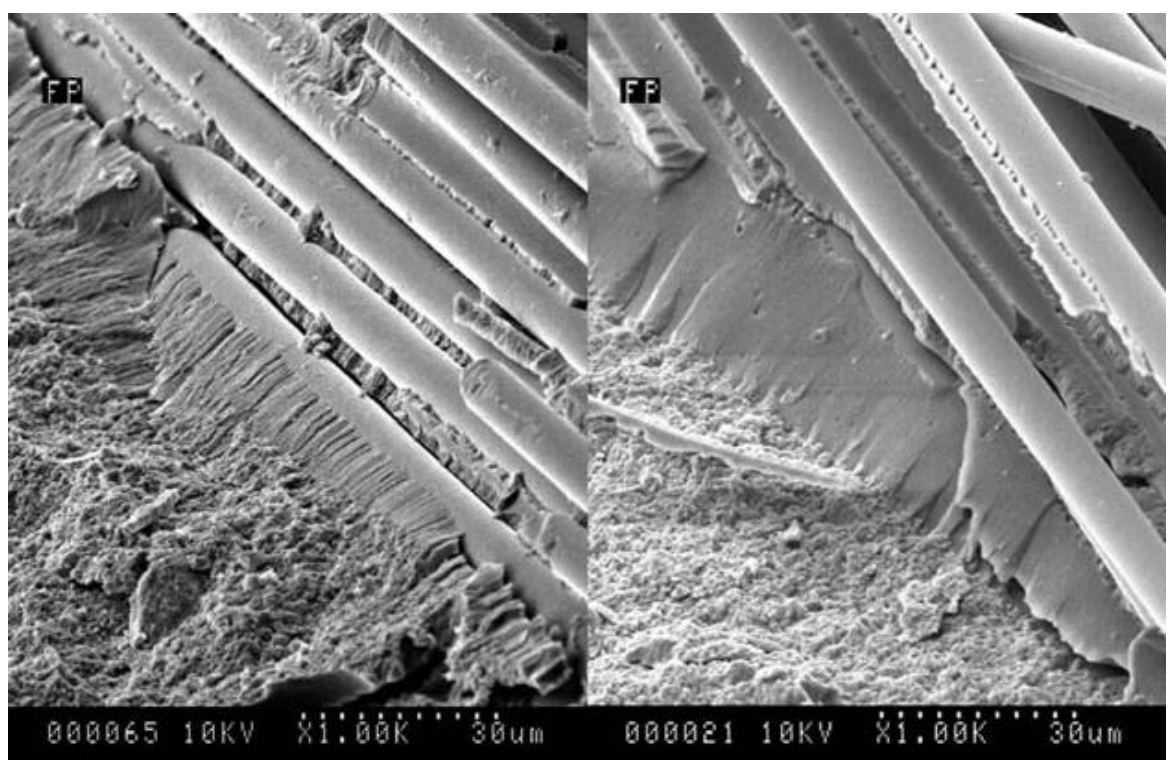

Figura 5.9 - Fotomicrografia do pino representante do Grupo 3. Espécimes com maior e menor valor, respectivamente. Aumento de $1000 \mathrm{X}$.

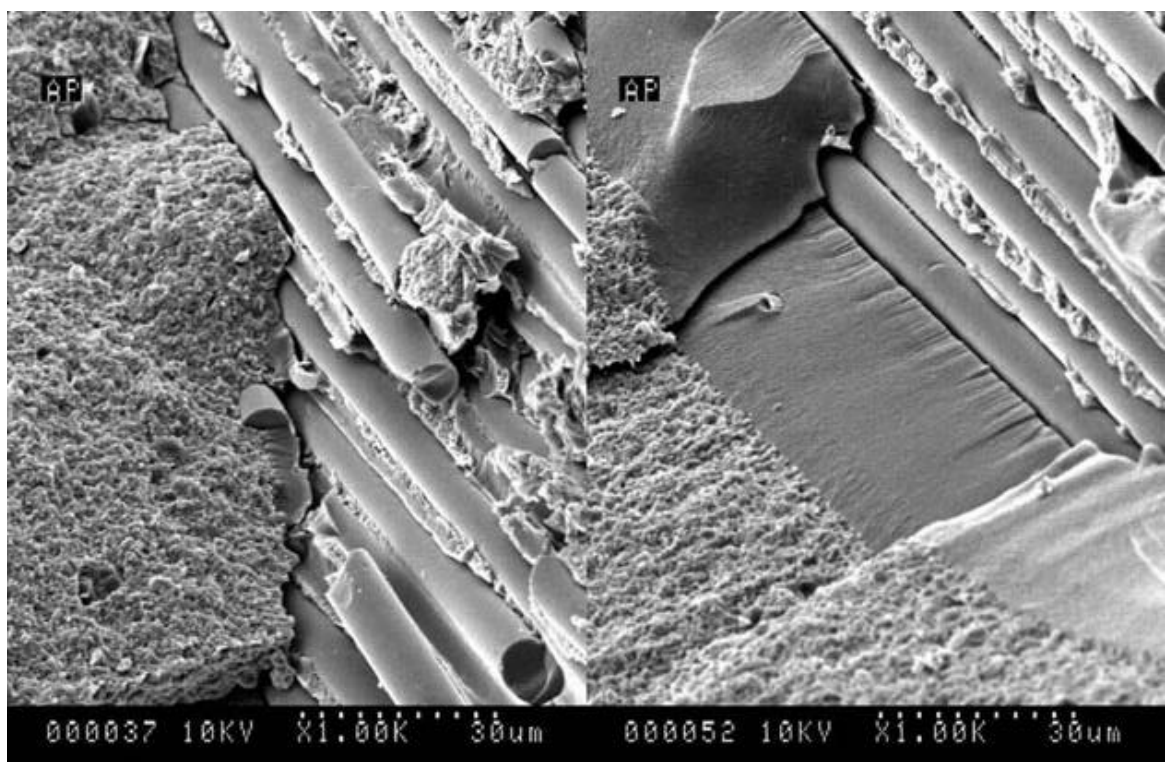

Figura 5.10 - Fotomicrografia do pino representante do Grupo 4. Espécimes com maior e menor valor, respectivamente. Aumento de $1000 \mathrm{X}$. 


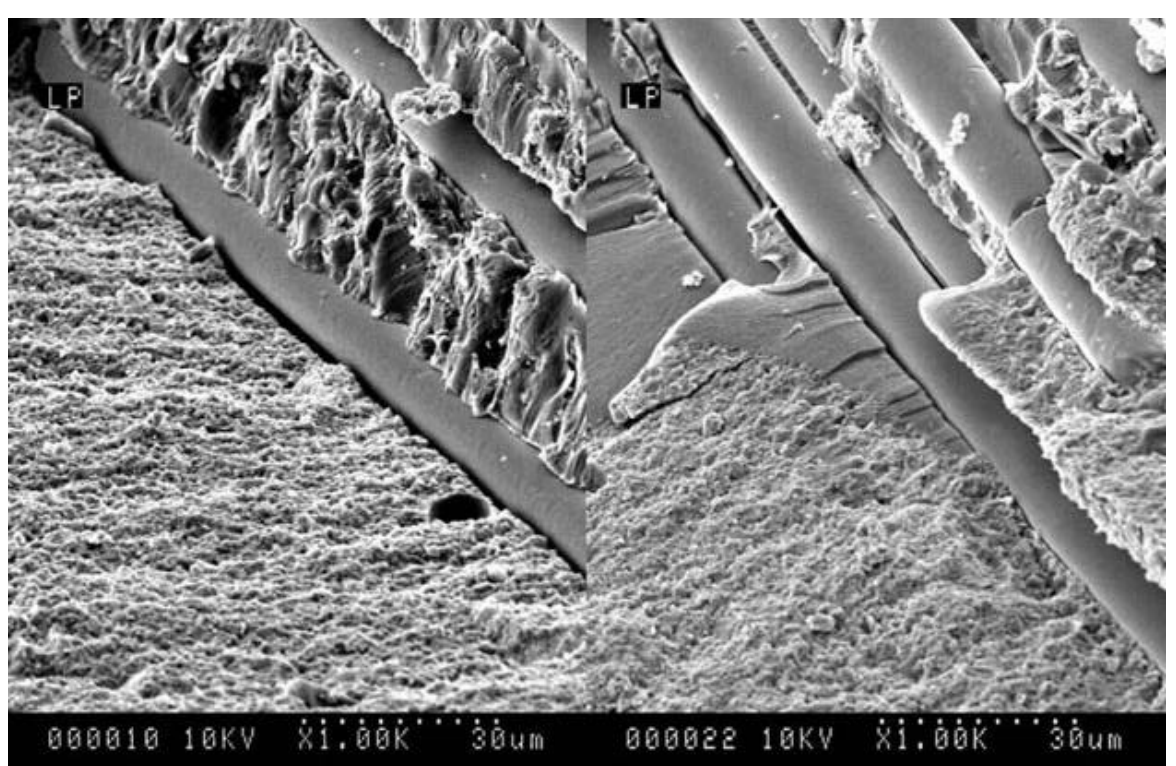

Figura 5.11 - Fotomicrografia do pino representante do Grupo 5. Espécimes com maior e menor valor, respectivamente. Aumento de $1000 \mathrm{X}$.

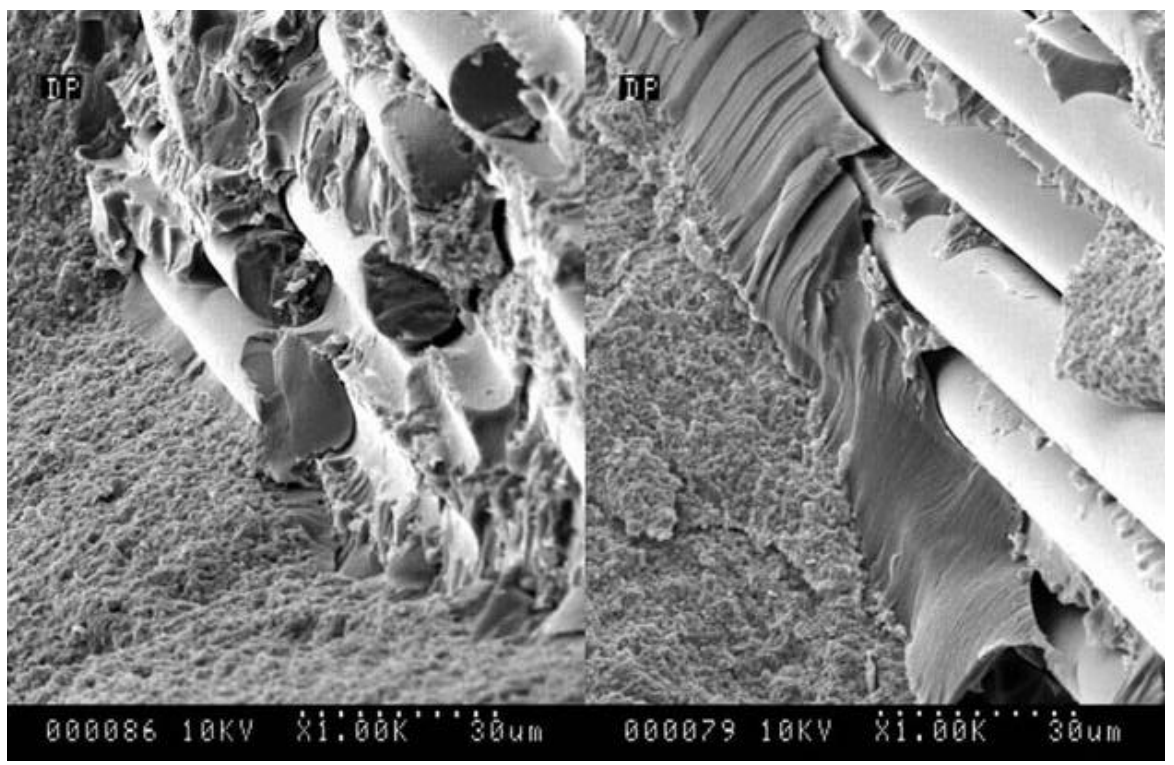

Figura 5.12 - Fotomicrografia do pino representante do Grupo 6. Espécimes com maior e menor valor, respectivamente. Aumento de $1000 \mathrm{X}$. 


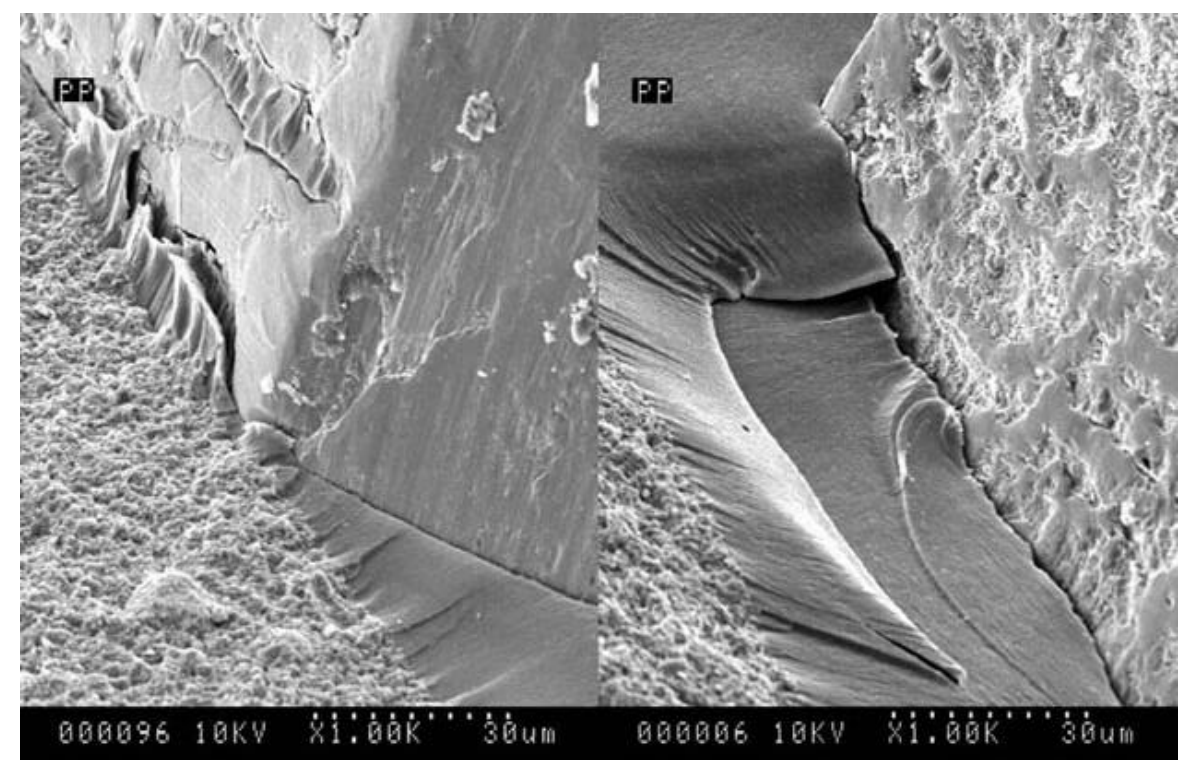

Figura 5.13 - Fotomicrografia do pino representante do Grupo 7. Espécimes com maior e menor valor, respectivamente. Aumento de $1000 \mathrm{X}$. 
W.

262

19.

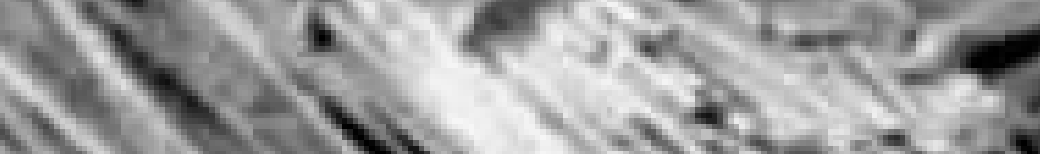

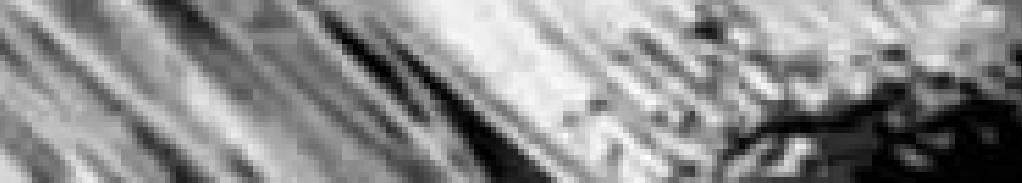

$1 \times 1$.

- 1 vere

1. 14.1 . को

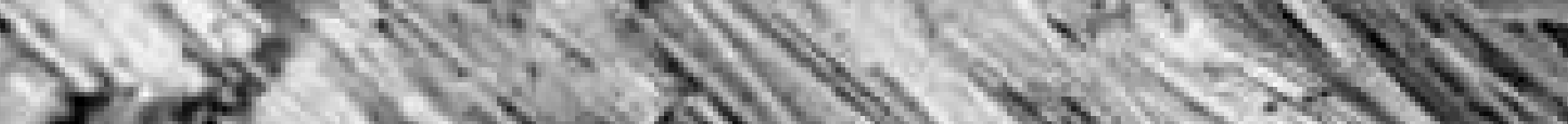

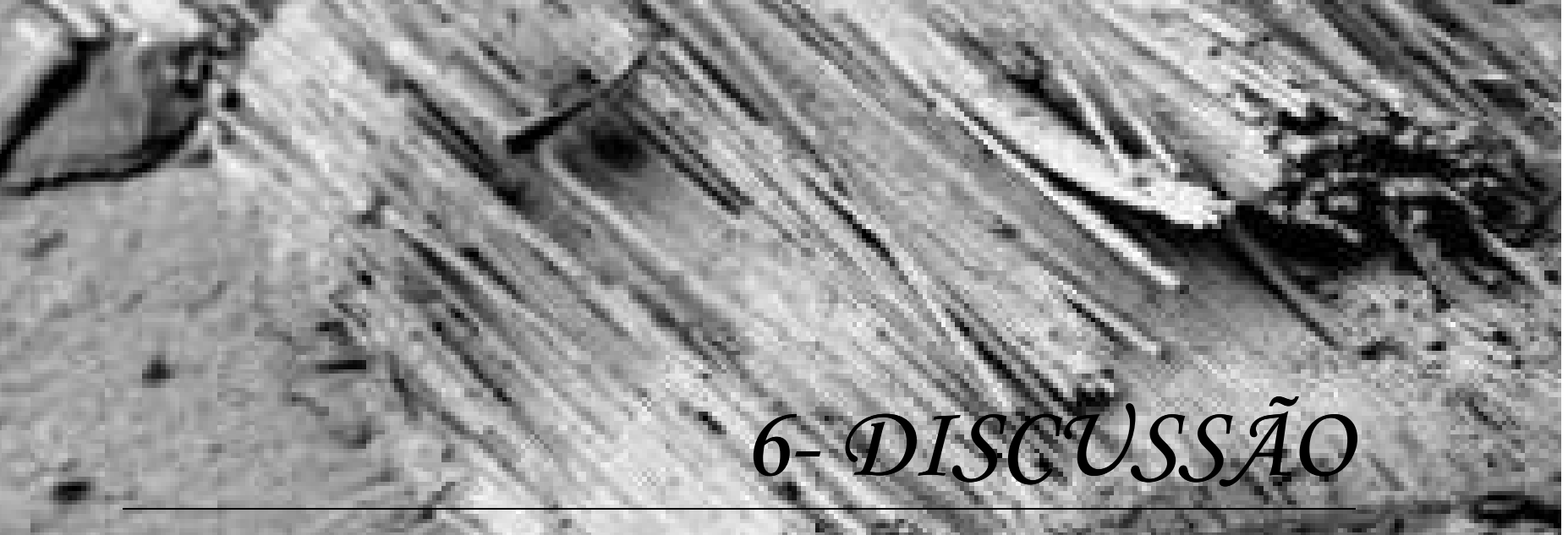

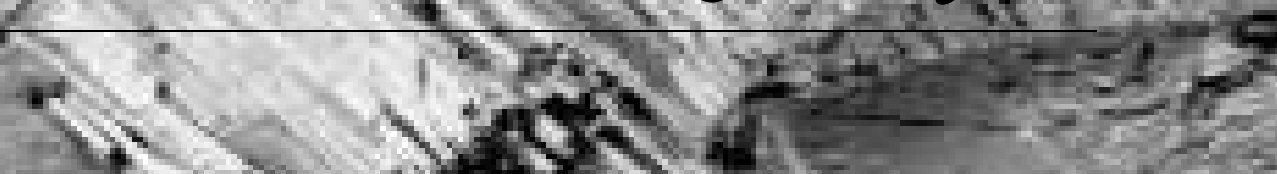

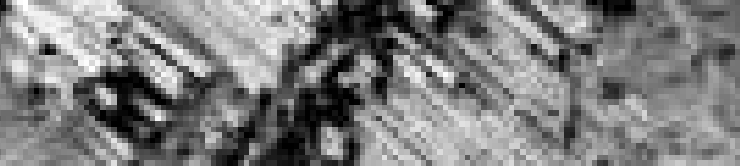

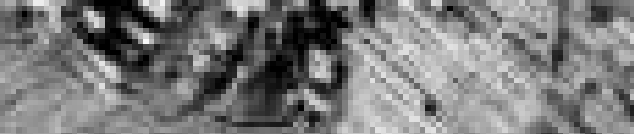

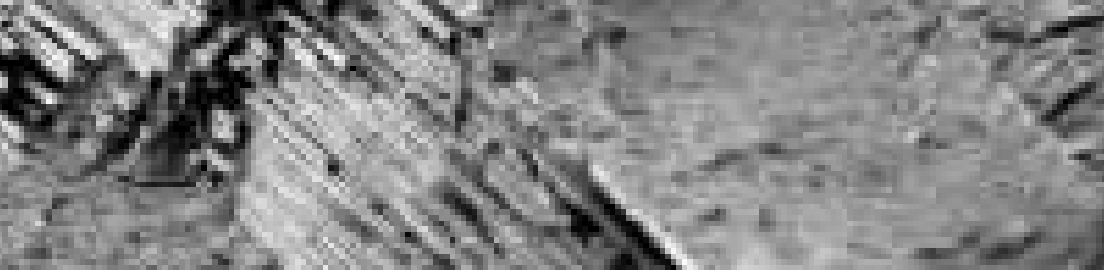




\section{6- DISCUSSÃO}

$\mathrm{Na}$ revisão de literatura pudemos observar que existe uma preferência pelo uso dos pinos pré-fabricados sobre os pinos metálicos fundidos. Com o crescimento das exigências estéticas e o desenvolvimento de sistemas aperfeiçoados de próteses livres de metal, cresceu também a necessidade de se desenvolver sistemas de pinos para o alcance da máxima estética possível. Segundo FRADEANI; AQUILANO; BARDUCCl ${ }^{21}$ (1999) e FERRARI et $\mathrm{al}^{20}$ (2000) a pigmentação dos pinos metálicos pode causar um manchamento e sombreamento na porção cervical da raiz. Uma vez que a transmissão de luz através da raiz é parcialmente responsável pela coloração dos tecidos gengivais, o uso de pinos que favoreçam esta transmissão é indicado, principalmente em pacientes com tecido periodontal fino ou com a linha de sorriso alta.

Autores como KWIATKOWSKI; GELLER ${ }^{36}$ (1989) e KAKEHASHI et al ${ }^{31}$ (1998) comentaram que os pinos estéticos têm a habilidade de permitir que a luz se propague no dente tanto no sentido coroa/raiz quanto no sentido inverso. HOCHMAN; ZALKIND²6 (1999) afirmaram que com o uso de pinos cerâmicos a translucidez das coroas em cerâmica pura pode ser mantida por causa da cerâmica prensada que constitui a porção coronária do pino. A cor branca e opaca do pino cerâmico pode ainda colaborar no aumento do valor da cor da porção radicular do dente. 
Apesar das vantagens estéticas, os pinos cerâmicos apresentam algumas desvantagens que devem ser consideradas no momento da seleção do material restaurador. Segundo KOUTAYAS; KERN ${ }^{35}$ (1999) os materiais cerâmicos são freqüentemente propícios à fratura porque eles não podem absorver tensões da mesma maneira que os metais e os polímeros. A alumina também exibe um comportamento de friabilidade e tem uma resistência à fratura relativamente baixa. Apresenta, ainda, uma sensibilidade às falhas microestruturais, o que leva a uma baixa resistência à concentração de esforços ou impactos mecânicos.

LOPES et $\mathrm{al}^{37}$ (2001) afirmaram ainda que, a dureza dos pinos cerâmicos pode causar fraturas dentais menos favoráveis, do ponto de vista de resolução clínica, quando comparadas aos pinos de fibras que apresentam módulo de elasticidade similar ao da dentina, podendo transmitir de maneira efetiva as tensões através do pino e estrutura radicular. Ainda ressaltam que os pinos de cerâmica também apresentam como desvantagem a dificuldade de remoção do conduto em caso de necessidade de retratamento endodôntico.

DE RIJK ${ }^{15}$ em 2000 afirmou que a necessidade de retratamento endodôntico tem sido estimada em 8 a $15 \%$ dos casos e os pinos de fibra são mais facilmente removidos em caso de retratamento endodôntico devido ao paralelismo de suas fibras, que ajuda a guiar as brocas de remoção mantendoas confinadas ao interior do pino.

MARTÍNEZ-GONZÁLES et al $^{41}$ em 2001 afirmaram que os pinos cerâmicos não aceitam deformação e tendem a resistir até seu limite elástico 
quando tanto o pino quanto a restauração se fraturam. Por outro lado, também segundo estes autores, os pinos de resina possuem um baixo módulo de elasticidade, apresentam boas características de deformação e memória elástica. Como resultado, pouca tensão é gerada na porção apical e uma quantidade menor de fratura é observada na mesma região.

Como alternativa aos pinos cerâmicos, surgiram os pinos reforçados por fibras que procuram corrigir alguns problemas inerentes à natureza da cerâmica, conservando, no entanto, as propriedades estéticas.

MANNOCCl et $\mathrm{al}^{39}$ (1999) e MARTELLI ${ }^{40}$ (2000) comentaram que os pinos de fibra de vidro apresentam módulo de elasticidade de $40 \mathrm{GPa}$, próximo da dentina (18,6 GPa) e dos cimentos resinosos (5 a 20 GPa). Também permitem a obtenção de uma restauração estética com sucesso e predictibilidade e, por este motivo devem ser a principal escolha para se restaurar dentes tratados endodonticamente, quando o fator "estética" for primordial.

Em relação ao material de reconstrução coronal, QUINTAS; DINATO; BOTTINO $^{47}$ (2000) afirmaram que o pino e o material de reconstrução coronária devem ser compatíveis, pois materiais semelhantes criam uma melhor interface com menos estresse entre os materiais e, conseqüentemente, menor micro-infiltração e potencial de falha.

A resistência é apenas um critério de seleção para o material de reconstrução coronal, porém crucial. Um material que resiste melhor à deformação e fratura, promove uma distribuição mais equilibrada dos esforços 
aplicados sobre o dente e reduz a probabilidade de falha compressiva ou de tração, aumentando a probabilidade de sucesso clínico.

COHEN et $\mathrm{al}^{7}$ (1992) comentaram que um material restaurador deve apresentar uma resistência similar à dentina, especialmente nos casos em que a porção coronal da restauração está constituída em parte por dentina e em parte pelo material restaurador. As propriedades semelhantes dos materiais previnem uma flexão da porção coronária sob função e evitam uma fadiga prematura do pino de preenchimento e da restauração. De acordo com CORMIER; BURNS; MOON ${ }^{11}$ em 2001, os pinos reforçados por fibras e o material de reconstrução coronária podem agir absorvendo os esforços oclusais e funcionais que são aplicados ao complexo coroa/pino redirecionando estas forças para o longo eixo da raiz remanescente.

Segundo O'MAHONY; SPENCER ${ }^{44}$ (1999) as resinas compostas têm apresentado um aumento de aceitação como material para reconstrução coronária devido à sua característica de adesividade aos tecidos dentais e por apresentar propriedades semelhantes à dentina. Entre as vantagens do uso deste material, destacam-se a facilidade de manipulação e a rapidez de polimerização, além do preparo para coroa imediatamente após a presa do material. Ressaltaram, entretanto que as limitações de uso deste material incluem a sorpção de água, com conseqüente falta de estabilidade dimensional e formação de fendas na margem compósito/dente como resultado da contração de polimerização e expansão e contração térmica. Para limitar estes 
problemas, aconselham o uso de técnica incremental de colocação do compósito.

Em nosso trabalho buscamos avaliar a interação dos pinos reforçados por fibra de vidro com o material restaurador (resina composta) tentando avaliar se algum sistema apresenta um resultado superior aos demais testados, o que implicaria numa expectativa maior de sobrevivência das restaurações definitivas.

Segundo QUINTAS; DINATO; BOTTINO ${ }^{47}$ (2000) a composição por peso dos pinos reforçados por fibras de vidro é: $42 \%$ de fibras de vidro, $29 \%$ de carga e $18 \%$ de resina. Estes pinos podem se apresentar em formato cônico ou paralelo e apresentam uma melhor estética final nas restaurações quando comparados aos pinos metálicos. Como os pinos são confeccionados com suas fibras posicionadas no sentido longitudinal, estas fibras apresentam como característica principal o reforço da estrutura dos pinos em relação aos esforços de dobramento. A composição dos pinos reforçados por fibras de quartzo é um pouco diferente, segundo FERRARI; VICHI; GARCÍA-GODOY ${ }^{19}$ (2000) estes pinos são compostos por $64 \%$ do seu em peso de fibras e $36 \%$ de matriz de resina epóxica.

Segundo FRADEANI; AQUILANO; BARDUCCl ${ }^{21}$ (1999) e FERRARI; VICHI; GARCÍA-GODOY ${ }^{19}$ (2000) a matriz resinosa que envolve as fibras dos pinos permite uma adesividade tanto ao cimento resinoso quanto ao material restaurador da porção coronária. Este tipo de pino pode ser colado ao dente com o uso de agentes de união e cimentos resinosos com flexibilidade 
semelhante, transmitindo de maneira mais efetiva os esforços entre o pino e a estrutura radicular, reduzindo com isto a concentração de estresse.

A adição de fibras a uma matriz polimérica causa um melhoramento significante nas propriedades mecânicas de resistência à fratura, dureza e resistência à fadiga dos materiais. As fibras de vidro apresentam resistência à tração de 2,5 a 4,5 GPa (DRUMMOND $\left.{ }^{17}, 2000\right)$. Segundo MANNOCCl et al ${ }^{39}$ (1999) as dimensões das fibras de reforço dos pinos variam entre 8 a $9 \mu \mathrm{m}$.

A disposição das fibras, no entanto, não permite que os pinos sejam comprimidos. Segundo os fabricantes, devemos evitar, por exemplo, cortá-los com alicates ou tesouras, pois isto danifica a estrutura do material. Por este motivo, pensamos em uma forma alternativa de avaliação das propriedades dos materiais, pois ao trabalharmos com o ensaio tradicional de Tração necessitamos prender uma porção do pino a um dispositivo que necessita comprimí-lo para mantê-lo em posição, causando danos que interferem nos resultados finais, pois a linha de fratura que se forma segue o sentido das fibras indo do local inicial até a porção final da fibra passando pelo interior da restauração.

A escolha pelo teste de tração diametral além de contornar os problemas de destruição do pino, serviu para avaliação do tipo de fratura encontrado entre a resina restauradora e o pino. Este tipo de ensaio é um método tradicional de teste para materiais friáveis, sendo recomendado pela AMERICAN DENTAL ASSOCIATION ${ }^{1}$ (ADA). Neste tipo de ensaio a força de compressão aplicada sobre um corpo gera uma pressão interna fazendo com que o corpo se 
deforme. Esta deformação tende a separar o corpo de prova em duas metades criando um momento de tração interna no corpo de prova. A força gerada é denominada de tração diametral. Desta forma, os pinos puderam ser testados sem comprometer sua característica estrutural.

A norma número 27 da $\mathrm{ADA}^{1}$ para materiais restauradores de resina determina a fórmula de cálculo em MPa para o ensaio de tração diametral. Esta fórmula é descrita como: $\mathrm{TD}=2 p /($ d.d.l) onde $p=$ carga, $d=$ diâmetro da amostra e $E=$ comprimento da amostra.

Dentre os pinos escolhidos para avaliação procuramos incluir pinos reforçados por fibras de vidro, fibras de quartzo e um tipo de pino metálico. HEW; PURTON; LOVE ${ }^{25}$ (2001) afirmaram que os pinos do sistema ParaPost normalmente são escolhidos para grupo controle devido aos dados na literatura indicando sucesso clínico e porque em vários países ele é usado como padrão para a indústria de pinos paralelos pré-fabricados.

A escassa literatura com o mesmo método e o crescente uso dos pinos reforçados por fibra estimularam a execução deste projeto, porém, como a metodologia deste trabalho foi adaptada a partir da norma 27 da $\operatorname{ADA}^{1}$, não encontramos trabalhos com a mesma técnica empregada. Isto dificultou a comparação dos resultados.

$\mathrm{Na}$ tabela 5.1, pudemos verificar que o desvio padrão de todos os grupos foi baixo o que reflete uma homogeneidade de resultados intragrupos. Verificamos também que a resina composta sem adição de pinos apresentou o 
maior resultado de resistência à tração diametral, confirmado pela análise estatística representada graficamente na figura 5.1 .

Este resultado revelou que nenhum pino reforçou a resina composta. Uma vez que a resina composta utilizada apresenta propriedades semelhantes à da dentina, podemos esperar que o mesmo comportamento se dê quando da avaliação do reforço destes pinos aos dentes. Este resultado poderia ser associado aos achados de KHAN et $\mathrm{al}^{33}$ (1996) em que os autores afirmam que os pinos intra-radiculares não colaboram para o aumento de resistência das raízes.

A resistência à tração diametral da resina composta Tetric Ceram foi de 49,64 \3,36MPa, valor superior ao mínimo exigido pela especificação da ADA $^{1}$ para resinas compostas usadas em restaurações diretas, em que se estipula que o valor mínimo de resistência à tração diametral deve ser de 24 a $34 \mathrm{MPa}$, valores também citados por $\mathrm{CHO}$ et $\mathrm{al}^{6}$ (1999).

Estes resultados são superiores aos obtidos por COHEN et $\mathrm{al}^{7}$ (1992) no qual os autores pesquisaram a resistência à compressão e à tração diametral de materiais de preenchimento coronário utilizando a norma número 27 da ADA (Tração diametral). Verificaram que a resina composta autopolimerizável TiCore (Essential Dental Systems), que é uma resina reforçada por titânio indicada para reconstrução coronal de dentes restaurados com pinos préfabricados, apresentou valor de 5.219 PSI (35,9 MPa). Também se assemelham aos de $\mathrm{CHO}$ et $\mathrm{al}^{6}$ (1999) que encontraram valores para as resinas compostas variando de 51 a $55 \mathrm{MPa}$. 
Dentre os pinos estudados, os pinos reforçados por fibras obtiveram de uma maneira geral um desempenho melhor que o pino metálico. Os pinos Light-Post, Dentorama e Fiber-Post apresentaram resultados estaticamente superiores ao ParaPost.

Estes resultados discordam dos encontrados por PURTON; PAYNE ${ }^{46}$ (1996) ressaltando que, no referido trabalho, foi avaliada a união do material restaurador a pinos de carbono (lisos) e a pinos metálicos (serrilhados) com o teste de resistência à tração convencional. Estes autores apresentaram como resultado um melhor desempenho de retentividade dos pinos metálicos serrilhados $(65,6 \pm 15,6 \mathrm{~kg}$ a $71,4 \pm 29,7 \mathrm{~kg})$ em relação aos pinos de carbono de superfície lisa $(34,4 \pm 6,7 \mathrm{~kg}$ a $38,9 \pm 12,1 \mathrm{~kg})$. Neste tipo de teste o tipo de força que atua sobre a interface pino/resina é de cisalhamento e as condições superficiais dos pinos influenciam no resultado final. Em nosso trabalho, o teste de tração diametral determina a união química entre o conjunto pino/resina devido ao fato de que a força que atua sobre o conjunto é puramente de tração.

Dentre os pinos reforçados por fibras, os que foram reforçados com fibra de vidro apresentaram resultados mais consistentes, uma vez que não houve diferença estatística entre eles. Os dois tipos de pinos reforçados com fibras de quartzo, apesar de serem produzidos pelo mesmo fabricante e apresentarem o mesmo tipo de fibra, tiveram resultados diferentes do ponto de vista estatístico. Este fato pode só ser explicado pela diferença na composição da matriz de resina epóxica que para o pino Light-Post é translúcida enquanto que no pino ÆEstheti-Plus ela é opaca. Esta opacidade pode ter interferido na condução de 
luz durante a fotopolimerização, resultando em uma menor polimerização da resina ao redor do pino. MARTELLI ${ }^{40}$ (2000) afirmou que pinos translúcidos permitem uma melhor transmissão de luz para o interior do canal, favorecendo a fotoativação do cimento resinoso utilizado para cimentá-los.

Ainda em relação à Figura 5.1, podemos verificar que os três melhores resultados de resistência à tração diametral foram de pinos com diâmetro variando de $1,15 \mathrm{~mm}$ a $1,5 \mathrm{~mm}$. Este achado nos permitir afirmar que pinos com dimensões reduzidas, reforçados por fibras se comportam de maneira semelhante aos pinos de dimensões maiores, no que diz respeito à tração diametral. Clinicamente, isto se traduz em economia de tecido dentinário quando do momento do preparo para o dente receber o pino, não se justificando o uso de pinos com maiores dimensões. Apesar disto, não podermos afirmar que o diâmetro dos pinos influenciou de maneira marcante na resistência à tração diametral uma vez que, pinos com 1,15 mm (Dentorama), 1,5 mm (Light-Post) e 2 mm (Vectris-Post) não apresentaram diferença estatística.

Uma maneira de se avaliar a influência do diâmetro do pino na resistência à tração diametral seria a condução de um novo trabalho comparando um mesmo tipo de pino variando o diâmetro.

Os resultados obtidos revelaram que todos os pinos testados apresentaram resistência suficiente para enfrentar os esforços mastigatórios. Em 1986, GIBBS et $a^{23}$ relataram que os valores médios da mordida humana é de $74 \mathrm{~kg}$ variando de 25 a $127 \mathrm{~kg}$. KILIARIDIS et $\mathrm{al}^{34}$ (1993), MANNOCCI; 
FERRARI; WATSON ${ }^{38}$ (1999), STRUB; PONTIUS; KOUTAYAS ${ }^{58}$ (2001) comentaram que, para a região anterior, a força de mordida varia entre $160 \mathrm{~N}$ a $270 \mathrm{~N}$ (aproximadamente 17 a $27 \mathrm{~kg}$ ).

A avaliação das fotografias da microscopia eletrônica de varredura (Figuras 5.2 a 5.7) mostrou que os pinos reforçados por fibras apresentam estruturas e tamanhos de fibras semelhantes. Estas fibras têm diâmetro ao redor de $8 \mu \mathrm{m}$, fato relatado anteriormente por PURTON; PAYNE ${ }^{46}$ (1996), MANNOCCI; FERRARI; WATSON ${ }^{38}$ (1999) e RAYGOT; CHAI; JAMESON ${ }^{48}$ (2001).

Pudemos observar que em todos os sistemas usados, a espessura do agente de união influenciou na resistência à tração diametral. Todos os corpos de prova que apresentavam uma maior espessura de película tiveram menor valor de resistência do que os pinos co menor espessura de película (Figuras 5.8 a 5.13). Este achado está de acordo com ZHENG et $\mathrm{al}^{61}$ (2001) que afirmou que a maior espessura de película dificulta a volatilização do solvente diminuindo a resistência do agente de união.

Apesar do uso de um aplicador descartável de agente de união para cada espécime e da busca por um controle na confecção dos corpos de prova, ainda assim ocorreram pequenas variações refletidas no desvio padrão dos grupos.

Todos os pinos reforçados por fibras apresentaram padrão de fratura coesiva enquanto que os pinos metálicos apresentaram falha adesiva. Dentre os pinos de fibras, o pino Fiber-Post apresentou um desenho de fratura um 
pouco diferente devido a sua configuração geométrica que busca associar retenção química à mecânica (Figuras 4.21 a 4.24). Esta forma pareceu melhorar o desempenho do pino apesar do resultado não ser estatisticamente diferente dos demais pinos de fibra, porém superior aos pinos metálicos.

Em nosso trabalho, os resultados obtidos e discutidos nos permitem afirmar que os pinos reforçados por fibra testados, associados à resina composta, se comportam de maneira semelhante e são uma alternativa reconstrutora viável para dentes destruídos que receberão coroas confeccionadas em sistemas sem infra-estrutura metálica. Do ponto de vista clínico, sabemos que estes pinos também podem apresentar falhas, mas, quando estas ocorrem, são menos severas ao contrário dos pinos metálicos e cerâmicos que apresentam um alto índice de falhas não tratáveis (CORMIER; BURNS; MOON $\left.{ }^{11}, 2001\right)$. Além disto, o retratamento das unidades com falhas endodônticas restauradas com pinos reforçados por fibras é simples porque as fibras podem ser facilmente removidas com brocas enquanto que para os dentes restaurados com pinos metálicos ou cerâmicos esta remoção é mais difícil.

Os ensaios laboratoriais apresentam como desvantagem a não reprodução de todos os fatores inerentes à clínica. Avaliações clínicas de longo prazo com estes materiais serão úteis para confirmar a previsibilidade desta alternativa restauradora, permitindo uma análise mais criteriosa, consolidando as bases para indicações e limitações desta técnica. 
W.

862

19.

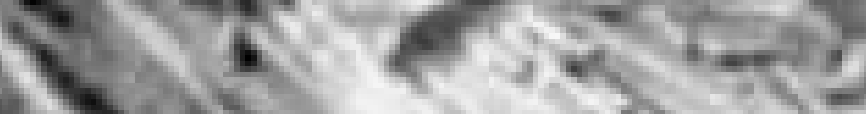

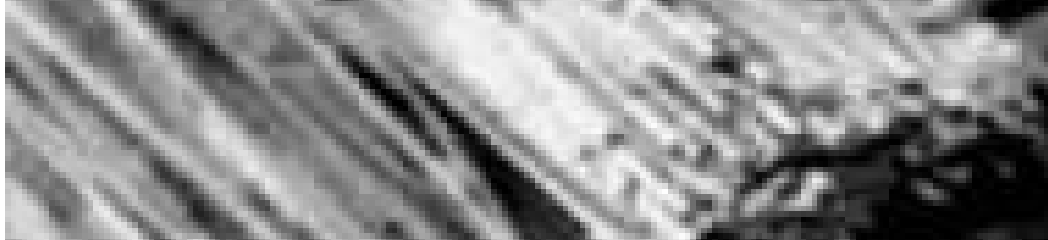

WhW Whaters

How Whes

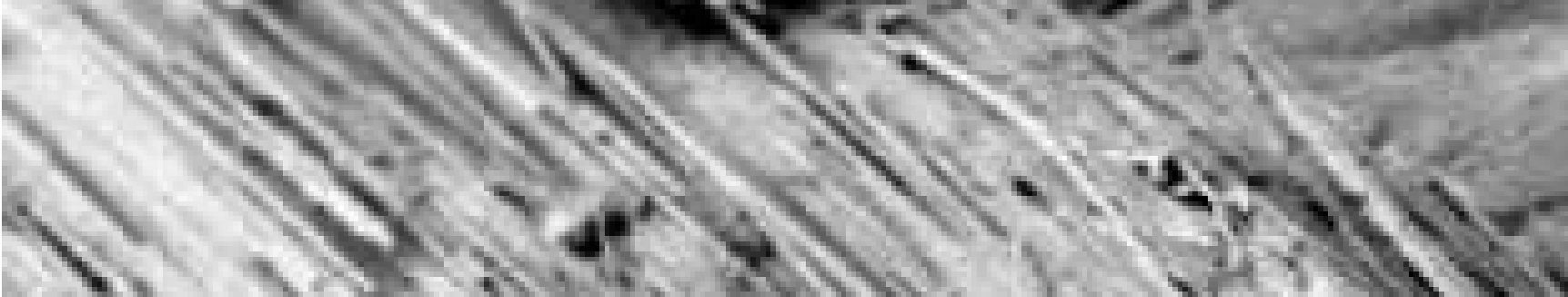

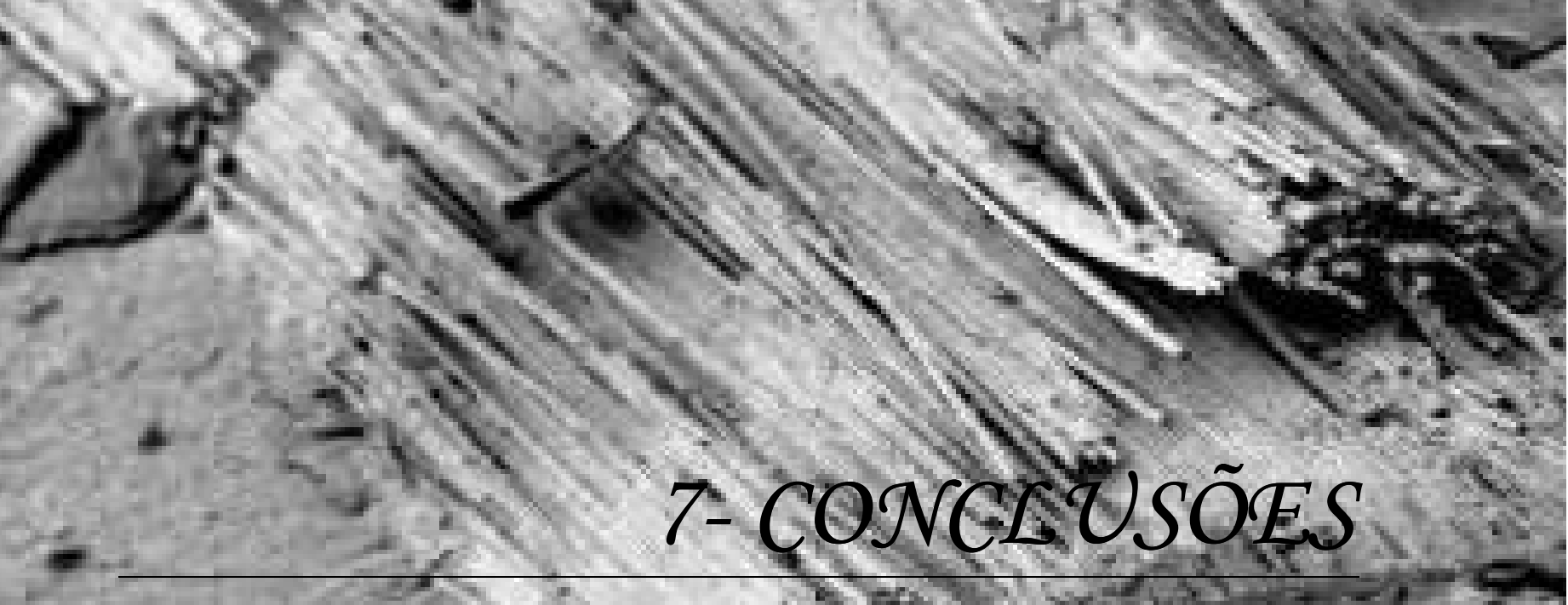

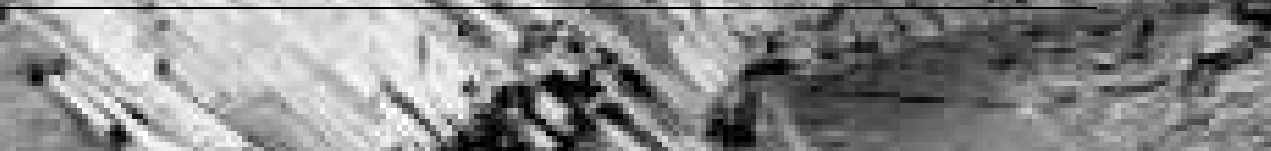

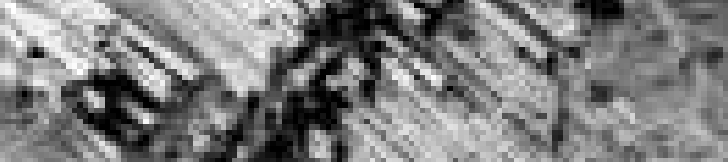

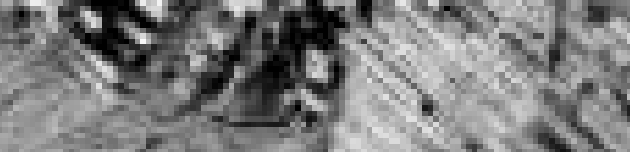

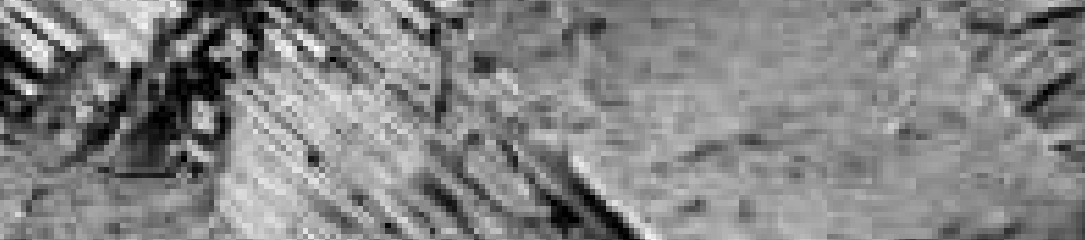

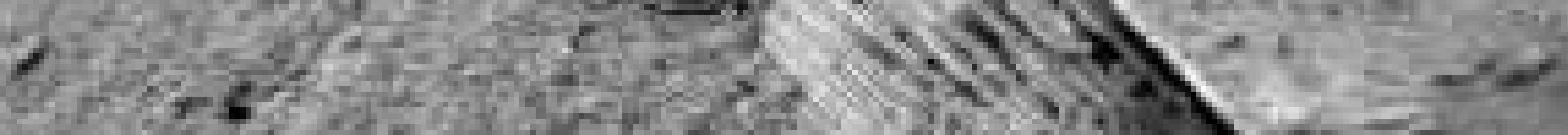

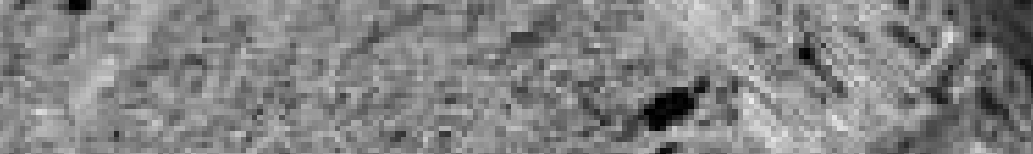




\section{7- CONCLUSÕES}

Com base na análise dos resultados obtidos, podemos concluir que:

1. Os pinos utilizados não reforçaram a resina composta;

2. Os pinos reforçados por fibra de vidro (G2, G3 e G6) apresentaram resultados mais consistentes que os pinos reforçados por fibra de quartzo (G4 e G5);

3. O pino metálico ParaPost apresentou o menor valor de adesão à resina de reconstrução coronal;

4. Os pinos Light-Post, Dentorama e Fiber-Post apresentaram os melhores valores de resistência no teste de tração diametral;

5. Os pinos reforçados por fibras apresentaram fratura coesiva enquanto o pino metálico apresentou fratura adesiva. 
W.

862

19.

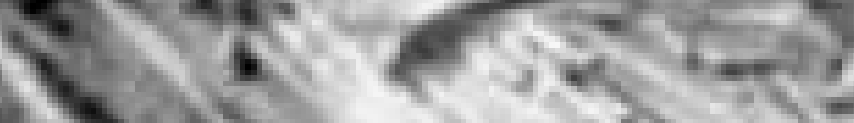

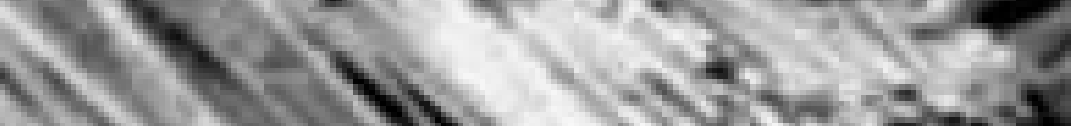

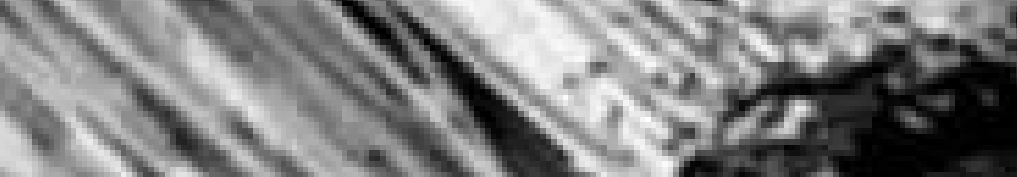

Whw wherepras

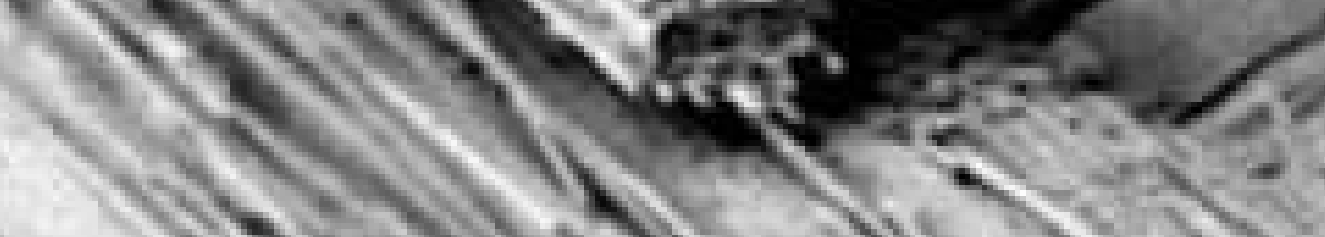

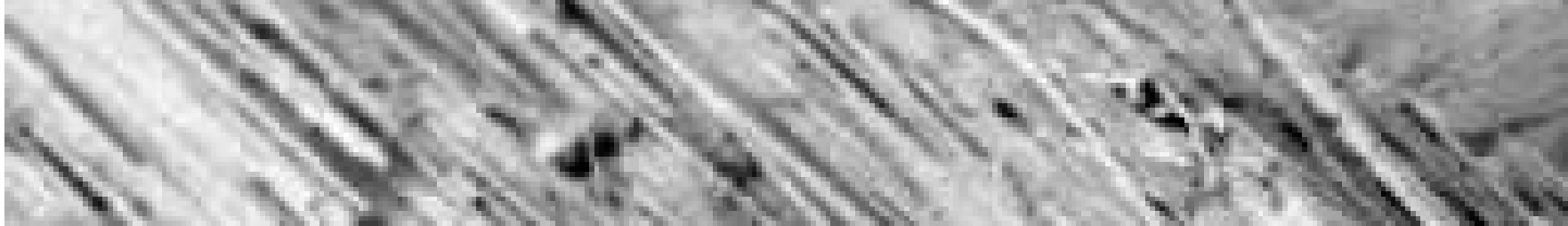
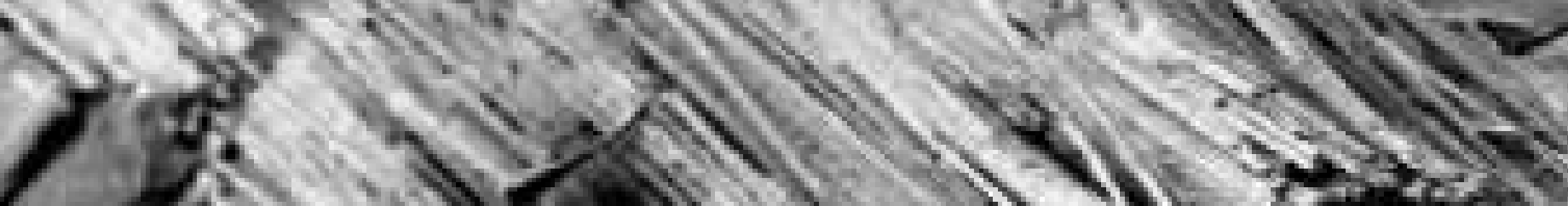

aw why

s.<smiles>C#[W]</smiles><smiles>C#CC#CC#N</smiles>

- 5 - 5 .

a ints
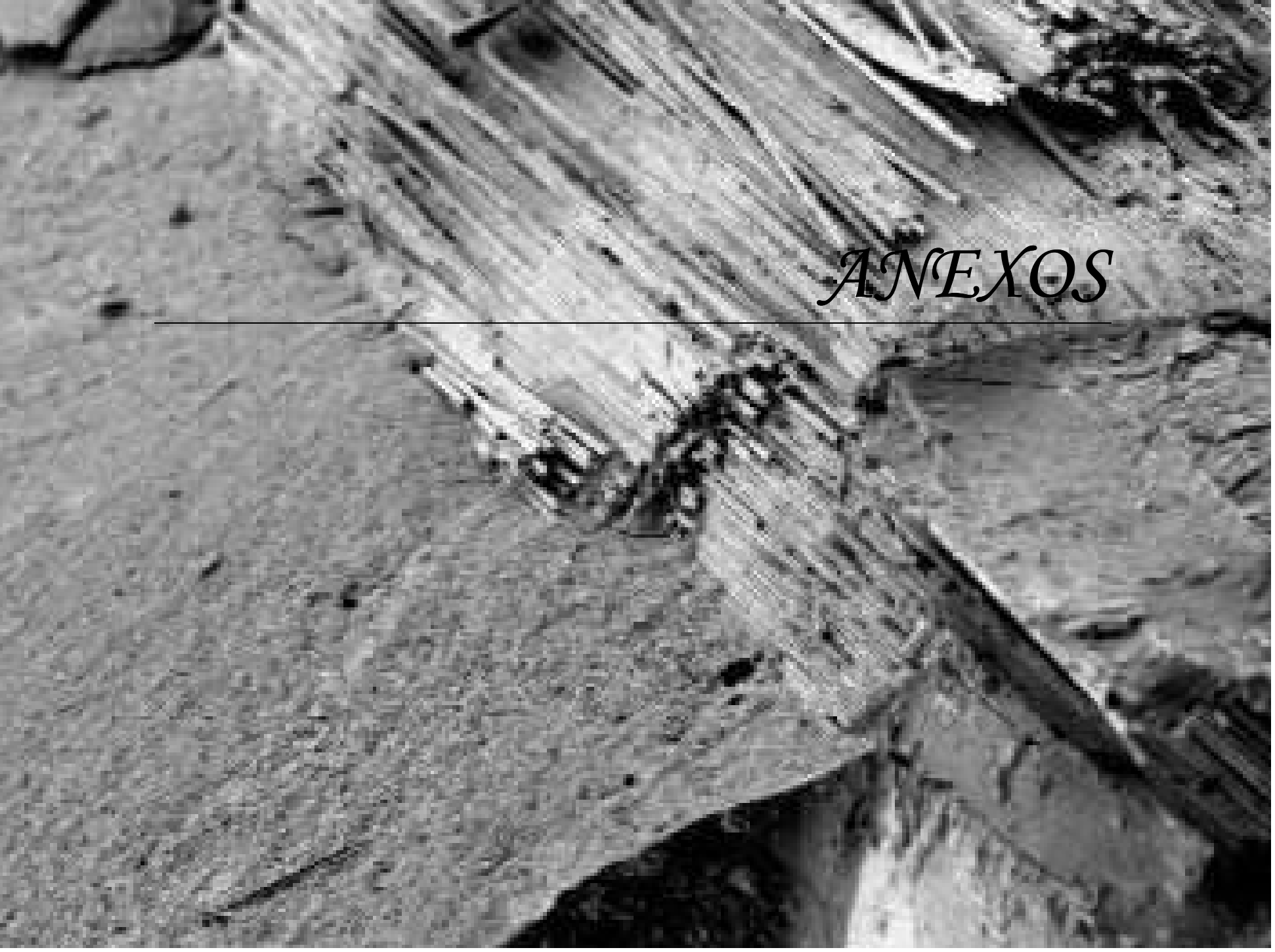
Anexo 1 - Valores obtidos no teste de tração diametral com os espécimes dos sete diferentes grupos testados (MPa). $\mathrm{n}=10$.

\begin{tabular}{cccccccc}
\hline GRUPO & G1 & G2 & G3 & G4 & G5 & G6 & G7 \\
AMOSTRA & & & & & & & \\
\hline 1 & 48,11 & 26,08 & 30,11 & 32,02 & 41,65 & 33,30 & 32,08 \\
2 & 57,01 & 26,88 & 32,28 & 32,02 & 34,53 & 35,97 & 27,46 \\
3 & 48,41 & 30,47 & 29,12 & 26,90 & 32,89 & 33,30 & 25,64 \\
4 & 48,11 & 29,97 & 33,47 & 29,17 & 34,78 & 31,43 & 26,17 \\
5 & 51,42 & 36,82 & 34,63 & 27,17 & 31,37 & 34,79 & 29,93 \\
6 & 50,48 & 25,08 & 30,09 & 27,03 & 31,53 & 38,51 & 28,37 \\
7 & 48,38 & 30,52 & 35,17 & 30,12 & 35,57 & 31,20 & 23,82 \\
8 & 52,40 & 30,58 & 32,00 & 26,90 & 35,85 & 33,19 & 29,81 \\
9 & 47,28 & 32,21 & 28,34 & 26,94 & 29,30 & 30,08 & 27,02 \\
10 & 44,86 & 29,09 & 33,86 & 31,02 & 35,16 & 32,81 & 28,76 \\
\hline Média & $\mathbf{4 9 , 6 4}$ & $\mathbf{2 9 , 7 7}$ & $\mathbf{3 1 , 9 0}$ & $\mathbf{2 8 , 9 2}$ & $\mathbf{3 4 , 2 6}$ & $\mathbf{3 3 , 4 5}$ & $\mathbf{2 7 , 9 0}$ \\
\hline D Padrão & $\mathbf{3 , 3 6}$ & 3,36 & 2,39 & 2,20 & 3,37 & 2,46 & 2,40 \\
\hline $\mathbf{n}$ & 10 & 10 & 10 & 10 & 10 & 10 & 10 \\
\hline
\end{tabular}




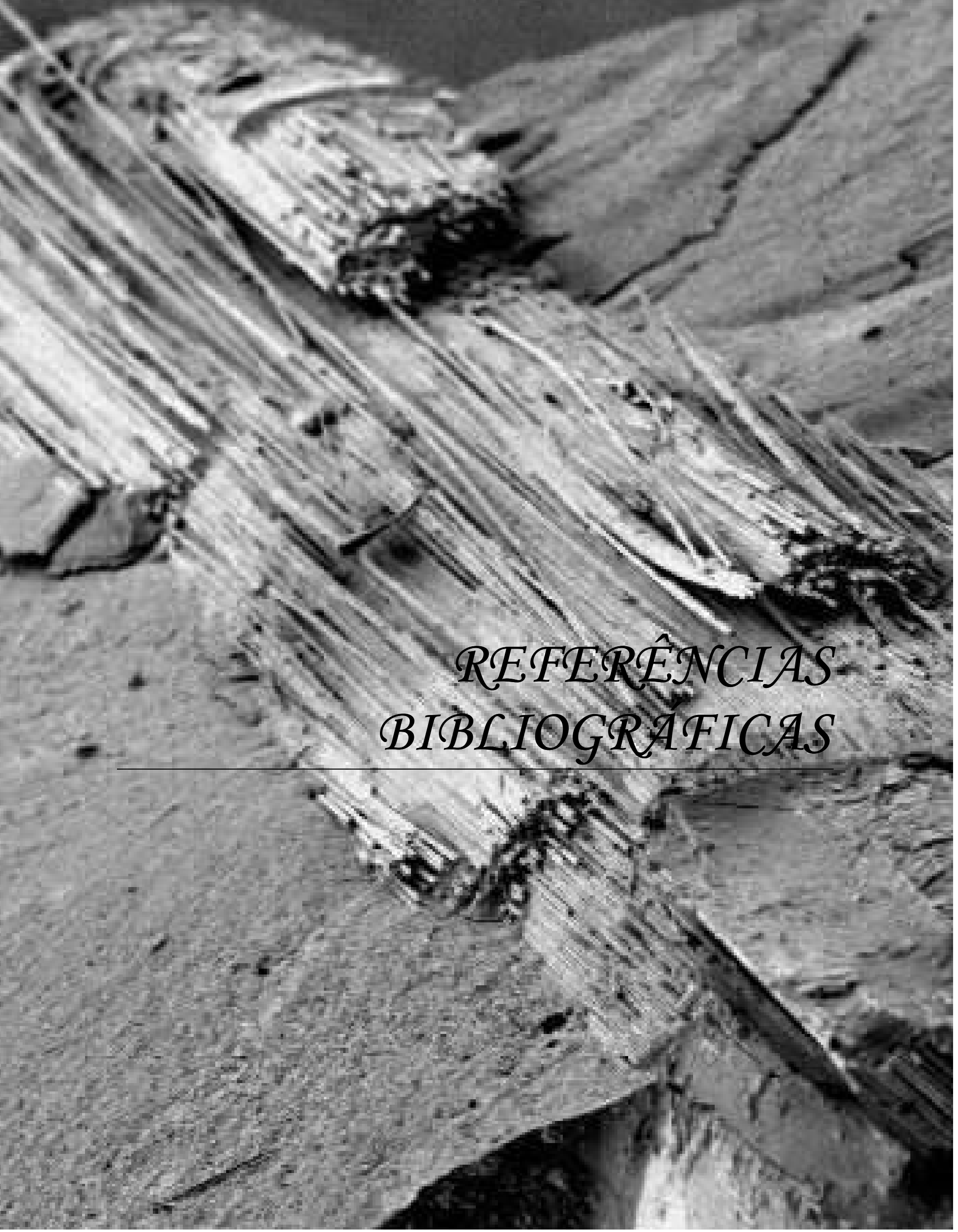


REFERÊNCIAS BIBLIOGRÁFICAS

1. AMERICAN DENTAL ASSOCIATION CERTIFICATION .PROGRAMS OF THE COUNCIL ON DENTAL MATERIALS, INSTRUMENTS AND EQUIPAMENTS. American National Standards Institution/American Dental Association Specification 27 for direct filling resins. Chicago: American National Standards Institution/American Dental Association; 1977.

2. AHMAD, I. Yttrium-partially stabilized zirconium dioxide post: an approach to restoring coronally compromised nonvital teeth. Int. J. Periodont. Restorat. Dent., v.18, n.5, p.454-65, Oct. 1998.

3. ASSIF, D.; GORFIL C. Biomechanical considerations in restoring endodontically treated teeth. J. prosth. Dent., v.71, n.6, p.565-7, June 1994

4. ASMUSSEN, E.; PEUTZFELDT A.; HEITMANN T. Stiffness, elastic limit, and strength of newer types of endodontic posts. J. Dent., v.27, n.4, p.275-8, May 1999.

5. BROWN, D.Fibre-reinforced materials. Dent. Update, v.27, n.9, p.442-8, Nov. 2000.

6. CHO, G.C. et al. Diametral and compressive strenght of dental core materials. J. prosth. Dent., v.82, n.3, p.272-6, Sept. 1999.

7. COHEN, B.I. et al. Compressive and diametral tensile strength of titanium-reinforced composites. J. Esthet. Dent., v. 4, p.50-5, 1992. Supplement. 
8. COHEN, B.I. et al. Pilot study of the cyclic fatigue characteristics of five endodontic posts with four core materials. J. oral Rehabil., v.27, n.1, p.83-92, Jan. 2000.

9. COHEN, B.I. et al. Retention of a core material supported by three post head designs. J. prosth. Dent., v.83, n.6, p.624-8, June 2000.

10. COHEN, B.I. et al. Torsional resistance of crowns cemented to composite cores involving three stainless steel endodontic post designs. J. prosth. Dent., v.84, n.1, p.38-42, July 2000.

11. CORMIER, C.J.; BURNS, D.R.; MOON, P. In vitro coparision of the fracture resistence and failure mode of fiber, ceramic, and conventional post systems at various stages of restoration. Int. J. Prosthodont., v.10, n.1, p.26-36, Mar. 2001.

12. CHRISTENSEN, G.J. Post and cores state of the art. J. Amer. dent. Ass., v.129, p.96-7, Jan. 1998.

13. COONEY, J.P.; CAPUTO, A.A.; TRABERT, K.C. Retention and stress distribution of tapered-end endodontics posts. J. prosth. Dent., v.55, n.5, p.540-6, May 1996.

14. CURY, A.A.D.B.; COSTA, W.F.DA. Restaurações de dentes tratados endodonticamente. Rev. Fac. Odont. Lins, v.3, n.2, p.22-7, jul./dez. 1990.

15. DE RIJK, W.G. Removal of fiber posts from endodontically treated teeth. Amer. J. Dent., v.13, p.19B-21B, May 2000. Special issue. 
16. DIETSCHI, D.; ROMELLI, M.; GORETTI, A. Adaptation of adhesive posts and cores to dentin after fatigue testing. Int. J. Prosthodont., v.10, n.6, p.498-507, Nov./Dec. 1997.

17.DRUMMOND, J.L. In vitro evaluation of endodontic posts. Amer. J. Dent., v.13, p.5B-8B, May 2000. Special issue.

18. EL-MOWAFY, O.; MILENKOVIC, M. Retention of Paraposts cemented with Dent.in-bonded resin cements. Oper. Dent., v.19, n.4, p.176-82, July/Aug. 1994.

19. FERRARI, M.; VICHI, A.; GARCIA-GODOY, F. Clinical evaluation of fiber-reinforced epoxy resin posts and cast post and cores. Amer. J. Dent., v.13, p.15B-18B, May 2000. Special issue.

20. FERRARI, M. et al. Retrospective study of the clinical performance of fiber post. Amer. J. Dent., v.13, p.09B-13B. May 2000. Special issue.

21. FRADEANI, M.; AQUILANO, A.; BARDUCCI, G. Aesthetic restoration of endodontically treated teeth. Pract. Periodont. Aesthet. Dent., v.11, n.7, p.761-8, Sept. 1999

22. FREDRIKSSON, M.; ASTBÄCK, J.; PAMENIUS, M. A restropective study of 236 patients with teeth restored by carbon fiber-reinforced epoxy resin posts. J. prosth. Dent., v.80, n.2, p.151-7, Aug. 1998.

23. GIBBS, C.H. et al. Limits of human bite strength. J. prosth. Dent., v.56, n.2, p.226-9, Aug. 1986.

24. HENRY, P.J. Photoelastic analysis of post core restorations. Aust. dent. J., v.22, n.3, p.157-9, June 1977. 
25. HEW, Y.S.; PURTON, D.G.; LOVE, R.M. Evaluation of pre-fabricated root canal posts. J. oral Rehab., v.28, n.3, p.207-11, Mar. 2001.

26. HOCHMAN, N.; ZALKIND, M. New all-ceramic indirect post-and-core system. J. prosth. Dent., v,81, n.5, p.625-9, May 1999.

27. HOLMES, D.C.; DIAZ-ARNOLD, A.M.; LEARY, J.M. Influence of post dimension on stress distribution in Dentin. J. prosth. Dent., v.75, n.2, p.140-7, Feb. 1996.

28. HSU, Y.B. et al. Effect of core bonding on fatigue failure of compromised teeth. J. Prostho., v.15, n.2, p.175-8, June 2002.

29. HUNTER, A.J.; FEIGLIN, B.; WILLIAMS, J.F. Effects of post placement on endodontically treated teeth. J. prosth. Dent., v.62, n.2, p.16672, Aug. 1989.

30. ISIDOR, F.; ÖDMAN, P.; BRONDUM, K. Intermittent loading of teeth restored using prefabricated carbon fiber posts. Int. J. Prosthodont., v.9, n.2, p.131-6, Mar./Apr. 1996.

31. KAKEHASHI, Y. et al. A new all-ceramic post and core system: clinical, technical, and in vitro results. Int. J. Periodont. Restorat. Dent., v.18, n.6, p.586-93, Dec. 1998.

32.KANTOR, M.E.; PINES, M.S. A comparative study of restorative techniques for pulpless teeth. J. prosth. Dent., v.38, n.4, p.405-12, Oct. 1977.

33. KHAN, F.H. et al. Comparison of fatigue for three prefabricated threaded post systems. J. prosth. Dent., v.75, n.2, p.148-53, Feb. 1996. 
34. KILIARIDIS, S. et al. The relationship between maximal bite force endurance, and facial morphology during growth. Acta odont. scand., v.51, n.5, p.323 -31, Oct. 1993.

35. KOUTAYAS, S.O.; KERN, M. All-ceramic posts and cores: the state of the art. Quintessence Int., v.30, n.6, p.383 -92, June 1999.

36. KWIATKOWSKI, S.J.; GELLER, W.A. A preliminary consideration of the glass-ceramic dowel post and core. Int. J. Prosth., v.2, n.1, p.51-5, Jan. 1989.

37. LOPES, G.C. et al. All-ceramic post, core, and crown: technique and case report. J. Esthet. Restor. Dent., v.13, n.5, p.285 -95, 2001.

38. MANNOCCI, F.; FERRARI, M.; WATSON, T.F. Intermittent loading of teeth restored using quartz fiber, carbon-quartz fiber, and zirconium dioxide ceramic root canal posts. J. Adhes. Dent., v.1, n.2, p.153-8, 1999.

39. MANNOCCI, F. et al. Confocal and scanning electron microscopic study of teeth restored using fiber posts, metal posts, and composite resins. J. Endod., v.25, n.1, p.789-94, Dec. 1999.

40. MARTELLI, R. Fourth-generation intraradicular posts for the aesthetic restoration of anterior teeth. Pract. Periodont. Aesthet. Dent., v.12, n.6, p.579-84, Aug. 2000.

41. MARTÍNEZ-GONZÁLES, A. et al. Response of three types of cast posts and cores to static loading. Quintessence Int., v.32, n.7, p.552-60, July/Aug. 2001. 
42. MONDELLI, J. Técnicas restauradoras para dentes com tratamento endodôntico. Rev. Dent. Rest., v.1, n.3, p.97-162, jul./set. 1998.

43. MORGANO, S.M. Restoration of pulplessteeth aplication of traditional principles in present and future contexts. J. prosth. Dent., v.75, n.4, p.375-80, Apr. 1996.

44. O'MAHONY, A.; SPENCER, P. Core build-up materials and techniques. J. Ir. Dent. Assoc., v.45, n.3, p.84-90, July/Sept. 1999.

45. OTTL, P. et al. Fracture caracteristics of carbon fibre, ceramic and nonpaladium endodontic post systems at monotonously increasing loads. J. oral Rehabil., v.29, n.2, p.175-83, Feb. 2002.

46. PURTON, D.G.; PAYNE, J.A. Comparison of carbon fiber and stainless steel root canal posts. Quintessence Int., v.27, n.2, p.93-7, Feb. 1996.

47. QUINTAS, A.F.; DINATO, J.C.; BOTTINO, M.A. Aesthetic posts and cores for metal-free restorations of endodontically treated teeth. Pract. Periodont. Aesthet. Dent., v.12, n.9, p.875-84, Nov./Dec. 2000.

48. RAYGOT, C.G.; CHAI, J.; JAMESON, L. Fracture resistence and primary failure mode of endodontically treated teeth restored with a carbon fiber-reinforced resin post system in vitro. Int. J. Prosthodont., v.14, n.2, p.141-5, Mar./Apr. 2001. 
49. ROSENSTIEL, S.F.; LAND, M.; HOLLOWAY, J.A. Custom-cast post fabrication with a thermoplastic material. J. prosth. Dent., v.77, n.2, p.209-11, Feb. 1997.

50. ROSENTRITT, M. et al. Comparison of in vitro fracture strength of metallic and tooth-coloured post and cores. J. oral Rehabil., v.27, n.7, p.595-601, July 2000.

51.SANTOS JÚNIOR, G.C.; FONTES, C.M. Estudo comparativo da resistência à tração de núcleos metálicos fundidos fixados com diversos tipos de cimento. Estudo in vitro. Rev. Fac. Odont. Univ. Fed. Bahia, v.19, p.16-8,jul./dez. 1999.

52. SANTOS JÚNIOR, G.C.; SANTOS, M.J.M.C.; BASTOS, L.G.C. Utilização de pino intra-radicular pré-fabricado do sistems luminex (Dentatus)- Relato de um caso clínico. Rev. Fac. Odont. Univ. Fed. Bahia, v.21, p.95-8, jul./dez. 2000.

53. SAUPE, W.A.; GLUSKIN, A.H.; RADKE JR, R.A. A comparative study of fracture resistance between morphologic dowels and cores and a resin-reinforced dowel system in the intraradicular restorations of structurally compromised roots. Quintessence Int., v.27, n.7, p.48391, July 1996.

54.SIRIMAI, S.; RIIS, D.N.; MORGANO, S.M. An in vitro study of the fracture resistance and the incidence of vertical root fracture of pulpless teeth restored with six post-and-core systems . J. prosth. Dent., v.81, n.3, p.262-9, Mar. 1999. 
55. STANDLEE, J.P. et al. The retentive and stress-distributing properties of a threated endodontic dowel. J. prosth. Dent., v.44, n.4, p.398-404, Oct. 1980.

56. STEGAROIU, R.S. et al. Retencion and failure mode afeter cyclic loading in two post and core systems. J. prosth. Dent., v.75, n.5, p.506-11, May 1996.

57.STOCKTON, L.W.; WILLIAMS, P.T. Retention and shear bond strength of two post systems. Oper. Dent., v.24, n.4, p.210-16, July/Aug. 1999.

58.STRUB, J.R.; PONTIUS, O.; KOUTAYAS, S. Survival rate and fracture strength of incisors restored with different post and core systems after exposure in the artificial mouth. J. oral Rehabil., v.28, n.2, p.120-4, Feb. 2001.

59. TORBJÖRNER, A.; KARLSSON, S.; ÖDMAN, P.A. Survival rate and failure characteristics for two post designs. J. prosth. Dent., v.73, n.5, p.439-44, May 1995.

60.XIBLE, A.A. Avaliação da resistência ao cisalhamento de três sistemas de núcleos intra-radiculares. Bauru, 2000. 92p. Dissertação (Mestrado) - Faculdade de Odontologia de Bauru, Universidade de São Paulo.

61.ZHENG, L. et al. Relationship between adhesive thickness and microtensile bond stength. Oper. Dent., v.26, n.1, p.97-104, Jan./Feb. 2001. 
W.

262

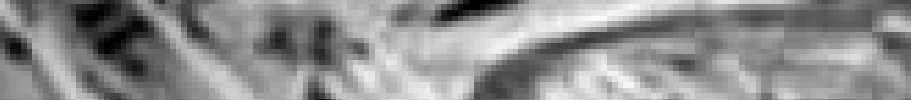

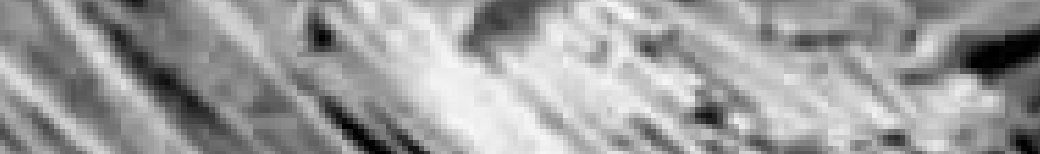

Now

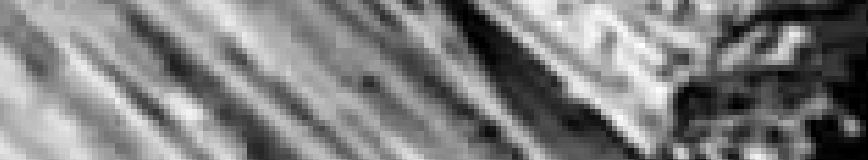

a 1 veres

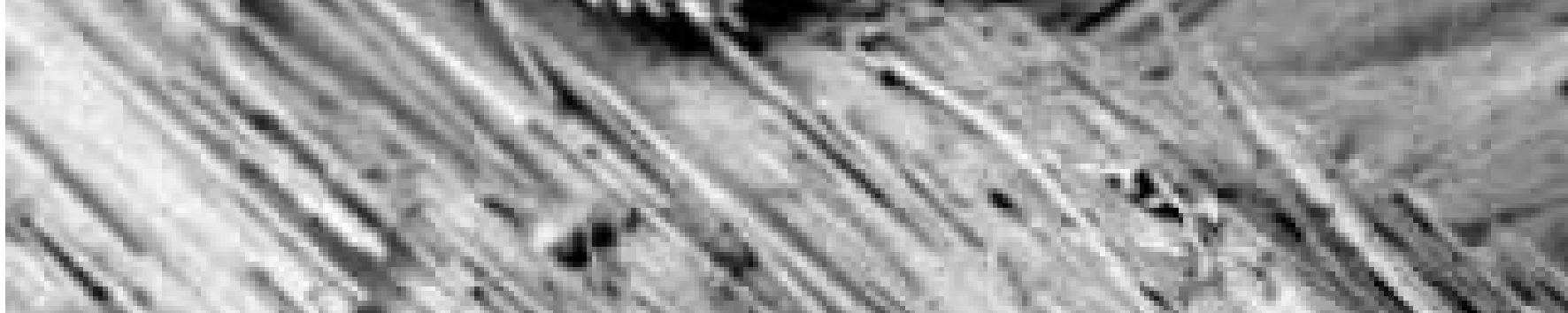

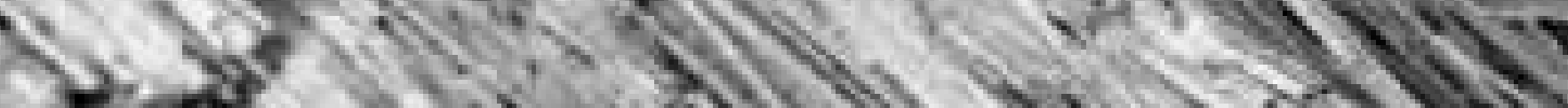

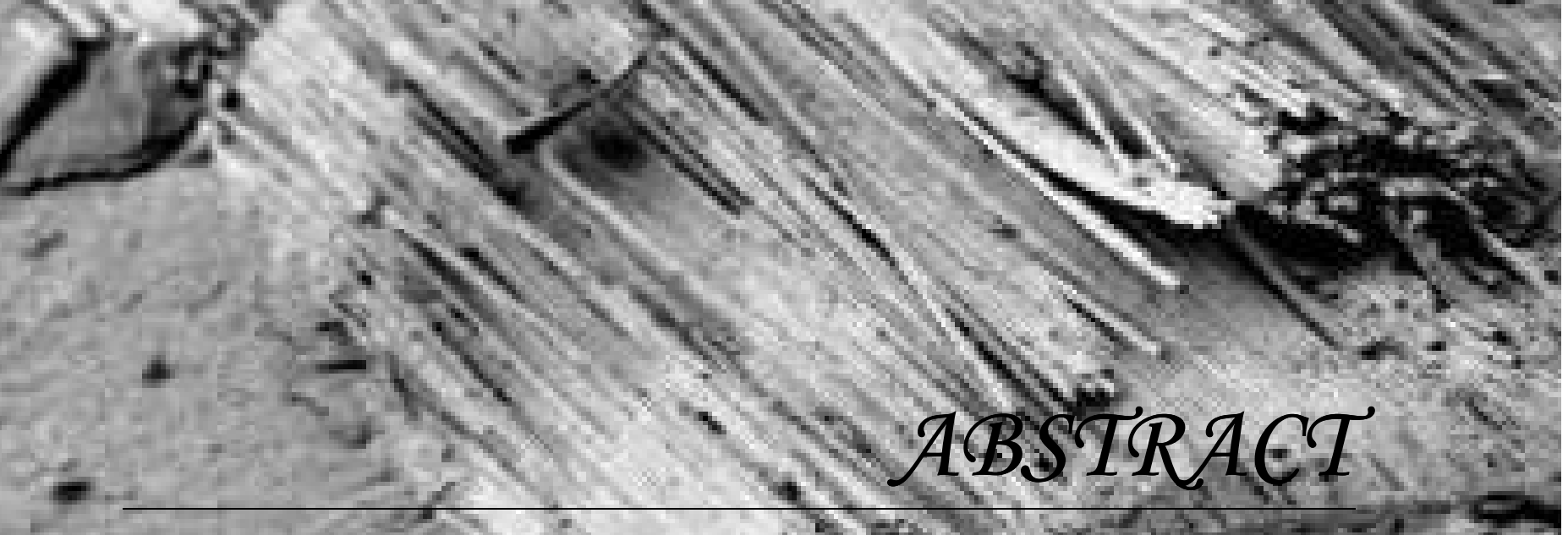

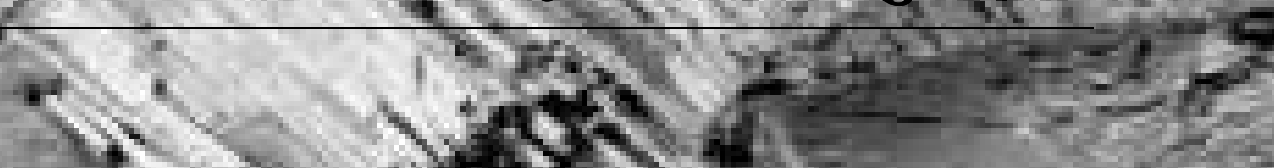

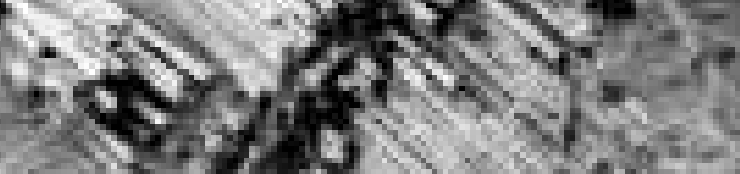

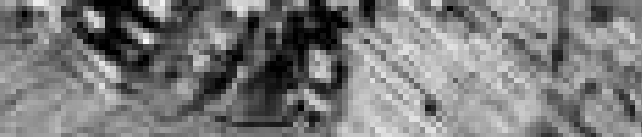

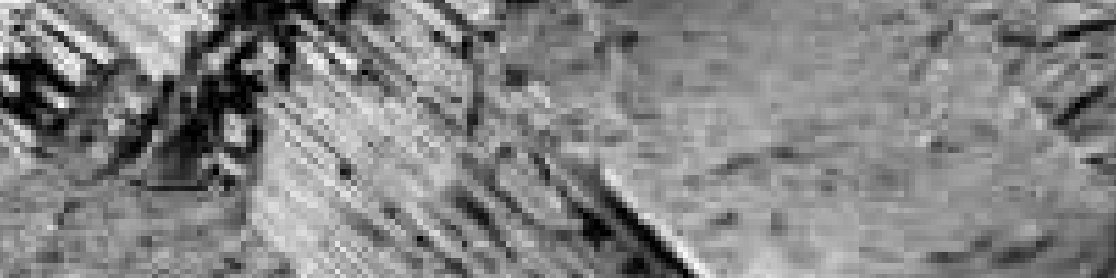




\begin{abstract}
"Diametral tensile strength of a resin composite core bonded to prefabricated posts."
\end{abstract}

The purpose of this study was to determine the influence of different types of posts on the fracture strength of a resin composite core material using the diametral tensile strength test. Seven groups of specimens were prepared each with 10 cylindrical specimens made of one composite material (Tetric Ceram, IvoclarVivadent) as follows: Group 1- Control group of composite only specimens; Group 2- Composite and VectrisPost (IvoclarVivadent); Group 3Composite and Fiber-Post (Jeneric/Pentron); Group 4- Composite and ÆEsthetiPlus post (Bisco); Group 5- Composite and Light-Post (Bisco); Group 6Composite and Dentorama post (Svenska) and group 7- Composite and ParaPost (Coltene/Whaledent). Following storage specimens were subjected to compressive loading in an Instron testing machine (model 8501) until failure occurred. Means and standard deviations of diametral tensile strengths in $\mathrm{MPa}$ were: Group 1- 49,64 (3,36); Group 2- 29,77 (3,36); Group 3- 31,9 (2,39); Group 4- 28,92 (2,20); Group 5- 34,26 (3,37); Group 6- 33,45 (2,46) and Group 7- $27,90(2,40)$. Statistical analysis revealed significant differences in mean diametral tensile strengths among the groups. It is concluded that the use of posts did not reinforce the composite resin cores. Among the post/core groups Light-Post, Dentorama post and Fiber-Post resulted in the highest values of tensile strength while ParaPost resulted in the lowest value of tensile strength. 